DENER MADEIRO DE SOUZA

\title{
ANÁLISE DE MARCADORES DE CÉLULAS TRONCO E PROGENITORES DAS CÉLULAS DE POLPA DENTÁRIA E DE VIBRISSAS DE CAMUNDONGOS C57BL6
}

Dissertação apresentada ao Programa de Pós-Graduação Interunidades em Biotecnologia USP/Instituto Butantan/IPT, para a obtenção do Título de Mestre em Biotecnologia. 
DENER MADEIRO DE SOUZA

\section{ANÁLISE DE MARCADORES DE CÉLULAS TRONCO E PROGENITORES DAS CÉLULAS DE POLPA DENTÁRIA E DE VIBRISSAS DE CAMUNDONGOS C57BL6}

Dissertação apresentada ao Programa de Pós-Graduação Interunidades em Biotecnologia USP/Instituto Butantan/IPT, para a obtenção do Título de Mestre em Biotecnologia.

Área de concentração: Biotecnologia

Orientadora: Profa. Dra. Irina Kerkis

Versão corrigida. A versão original eletrônica, encontrase disponível no ICB e na Biblioteca Digital de Dissertações e Teses da USP 
DADOS DE CATALOGAÇÃO NA PUBLICAÇÃO (CIP)

Serviço de Biblioteca e Informação Biomédica do

Instituto de Ciências Biomédicas da Universidade de São Paulo

(C) reprodução total

Souza, Dener Madeiro de.

Análise de marcadores de células tronco e progenitores das células de polpa dentária e de vibrissas de camundongos C57BL6 / Dener Madeiro de Souza. -- São Paulo, 2016.

Orientador: Irina Kerkis.

Dissertação (Mestrado) - Universidade de São Paulo. Instituto de Ciências Biomédicas. Programa de Pós-Graduação Interunidades em Biotecnologia USP/IPT/Instituto Butantan. Área de concentração:

Biotecnologia. Linha de pesquisa: Células tronco.

Versão do título para o inglês: Analysis of stem cells and progenitor markers of dental pulp cells and whiskers of C57BL6 mice.

1. Célula tronco 2. Folículo piloso 3. Polpa dentária 4. Marcadores de células tronco pluripotentes 5. Imunohistoquímica 6 .

Imunofluorescência I. Irina Kerkis II. Universidade de São Paulo. Instituto de Ciências Biomédicas. Programa de Pós-Graduação Interunidades em Biotecnologia USP/IPT/Instituto Butantan III. Título.

ICB/SBIB074/2016 


\section{UNIVERSIDADE DE SÃO PAULO \\ Programa de Pós-Graduação Interunidades em Biotecnologia}

Universidade de São Paulo, Instituto Butantan, Instituto de Pesquisas Tecnológicas

Candidato(a): Dener Madeiro de Souza.

Título: Análise de marcadores de células tronco e progenitores das células de polpa dentária e de vibrissas de camundongos C57BL6.

Orientador(a): Irina Kerkis.

A Comissão Julgadora dos trabalhos de Defesa da Dissertação de Mestrado, em sessão pública realizada a ....... considerou

\section{( ) Aprovado(a) ( ) Reprovado(a)}

Examinador(a) Assinatura:

Nome:

Instituição:

Examinador(a) Assinatura:

Nome:

Instituição:

Presidente Assinatura:

Nome:

Instituição: 


\section{COMISSÃO DE ÉTICA NO USO DE ANIMAIS (CEUAIB) \\ INSTITUTO BUTANTAN}

\section{CERTIFICADO}

Certificamos que o projeto intitulado "Análise de marcadores de células tronco e progenitores das células de polpa dentária e de vibrissas de camundongos C57BL6", protocolo $\mathrm{n}^{\circ}$ 1079/13, sob a responsabilidade de Irina Kerkis e Dener Madeiro de Souza que envolve a criação e/ou utilização de animais pertencentes ao filo Chordata, subfilo Vertebrata (exceto o homem), para fins de pesquisa científica - está de acordo com os preceitos da Lei $n^{\circ} 11.794$, de 8 de outubro de 2008, do Decreto 6.899, de 15 de julho de 2009 e de normas complementares, bem como está de acordo com os Princípios Éticos na Experimentação Animal adotado pelo Colégio Brasileiro de Experimentação Animal (COBEA), e foi aprovado pela COMISSĀO DE ÉTICA NO USO DE ANIMAIS DO INSTITUTO BUTANTAN (CEUAIB) em reunião de 20/4/2016.

\begin{tabular}{|c|c|c|}
\hline $\begin{array}{c}\text { Vigência do Projeto: } \\
\text { 08/2013-04/2018 }\end{array}$ & $\mathbf{N}^{\circ}$ de animais/espécie & Observação \\
\hline Laboratório de Genética & Sem adição de animais & $\begin{array}{c}\text { Alteração de título do } \\
\text { projeto }\end{array}$ \\
\cline { 2 - 3 } & &
\end{tabular}

São Paulo, 25 de abril de 2016

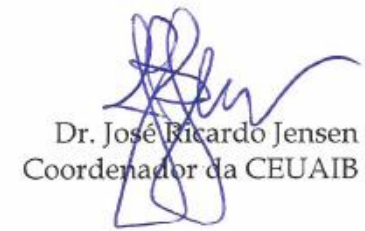




\section{A DEUS primeiramente;}

À minha mãe, que decidou sua vida aos filhos;

A meu irmão, que mesmo longe se faz presente;

A Joseilton, que é minha outra metade. 


\section{AGRADECIMENTOS}

À minha "chefinha" e professora Irina Kerkis, pela confiança em mim depositada e pela oportunidade a mim cedida;

À Cristiane Valverde Wenceslau, pela paciência e conhecimento a mim oferecidos durante toda essa jornada;

Ao Eduardo Osório Frare, por toda a ajuda oferecida, fundamental para a concretização desta dissertação;

Aos amigos de pós-graduação Lisley, Bruna, Bábyla, Nelson, Jéssica, Celine, Milena, Marcelly, Nicole, Gustavo, Paulo, Diana (Grilo), André (Gato), Leandro (Panda), André (Zaka), Allan (Coallan), Vivian e Bárbara, por fazer o Laboratório de Genética do Instituto Butantan o melhor lugar para se trabalhar. E por tudo que vivemos fora do trabalho... Nossas 'festiócas", aniversários e praias.

À Mirtes, Angelina, Fátima, Ana Paula, Ronaldo e Fagundes, funcionários do Laboratório de Genética que direta e indiretamente ajudaram neste trabalho. E que são minha segunda família... 
"O que nos cabe, é decidir o que fazer com o tempo que nos é dado" 


\section{RESUMO}

MADEIRO DE SOUZA, D. Análise de marcadores de células tronco e progenitores das células de polpa dentária e de vibrissas de camundongos C57BL6. 2016. $126 \mathrm{f}$. Dissertação (Mestrado em Biotecnologia). São Paulo: Instituto de Ciências Biomédicas, São Paulo, 2016

Os tecidos da polpa dentária e vibrissa são dois microambientes celulares que compartilham a mesma origem embrionária da crista neural. Ambos possuem o seu nicho específico pós-natal que abrigam células tronco adultas (CTAs). Desta forma, o objetivo do presente trabalho foi realizar a análise comparativa dos marcadores de células pluripotentes, mesenquimais e neuroepiteliais tanto ex vivo dentro do seu sítio anatômico - nicho celular (vibrissa e polpa dentária), quanto in vitro nas populações das culturas primárias de células tronco das vibrissas (CTV) e polpa dentária (CTPD) utilizando como modelo a linhagem de camundongos C57BL-6. Para tal investigação e validação dos resultados obtidos foram utilizados diversos métodos, tais como, imunohistoquímica, imunofluorescência, citometria de fluxo e reação em cadeia da polimerase (PCR). A análise da expressão utilizando o método de immunohistoquímica ex vivo de um amplo painel de marcadores como os de pluripotência (Oct4, Nanog e Sox2), mesenquimais (CD73, CD90 e CD105), hematopoiético (CD34), da crista neural (CKit), neuronal (Nestina), epiteliais (Integrina $\alpha 6$ e Citoqueratina 15) e folículos pilosos (Blimp1, LRig1, LGR5 e LGR6) revelou distribuição diferencial destes marcadores em diversos sítios anatômicos em polpa dentária e vibrissa. Utilizando o método do explante foi possível isolar CTV e CTPD de ambos tecidos. Caracterização in vitro da expressão de marcadores imunofenotípicos para células tronco nas culturas primárias das CTV e CTPD demonstrou que ambas populações celulares expressam um espectro parecido de marcadores de células tronco, porém em proporções diferentes. A semelhança imunofenotípica observada entre CTV e CTPD no presente trabalho corrobora com a origem embrionária comum destas células. Demonstramos ainda que CTPD expressam um espectro mais amplo dos marcadores estudados quando comparadas com CTV. Interessante que CTPDs foram positivas para LRig1 e Blimp1, que são consideradas principais marcadores de CTV. Desta forma, o estudo comparativo da expressão de um amplo painel de marcadores de células tronco em CTV e CTPD sugerem que células isoladas de ambos tecidos podem ser potencialmente promissoras e vir a aumentar o leque de possibilidades de sua utilização na terapia celular e na medicina regenerativa.

Palavras chaves: Células tronco. Folículo piloso. Polpa Dentária. Marcadores de células tronco pluripotentes. Imunohistoquímica. Imunofluorescência. 


\begin{abstract}
MADEIRO DE SOUZA, D. Analysis of stem cells and progenitor markers of dental pulp cells and vibrissae of C57BL6 mice. 2016. 126 p. Masters thesis (Biotechnology) - São Paulo: Instituto de Ciências Biomédicas, Universidade de São Paulo, São Paulo, 2016

The tissues of the dental pulp and vibrissae are two cellular microenvironments that share the same embryonic origin of the neural crest. Both possess their specific postnatal niche harboring adult stem cells (ASCs). Thus, the goal of the present work was to perform the comparative analysis of the pluripotent, mesenchymal and neuroepithelial cell markers both ex vivo within their anatomical site - cell niche (vibrissae and dental pulp), such as in vitro in populations of primary culture of vibrissae hair follicle bulge-derived stem cell (HFSC) and dental pulp stem cell (DPSC) using the C57BL-6 mouse as a model. For such investigation and validation of the obtained results several methods were used, such as immunohistochemistry, immunofluorescence, flow cytometry and polymerase chain reaction (PCR). Ex vivo expression analysis using the immunohistochemical method of a broad panel of markers such as pluripotency (Oct4, Nanog and Sox2), mesenchymal (CD73, CD90 and CD105), hematopoietic (CD34), neural crest (CKit), neuronal (Nestin), epithelial (Integrin $\alpha 6$ and Cytokeratin 15) and hair follicles (Blimp1, LRig1, LGR5 and LGR6) revealed differential distribution of these markers in several anatomical sites in dental pulp and vibrissae. Using the explant method it was possible to isolate HFSC and DPSC from both tissues. In vitro characterization of the expression of immunophenotypic markers for stem cells in the primary cultures of HFSC and DPSC has demonstrated that both cell populations express a similar spectrum of stem cell markers, but in different proportions. The immunophenotypic similarity observed between HFSC and DPSC in the present work corroborates by the common embryonic origin of these cells. We also demonstrated that DPSC express a broader spectrum of the markers studied when compared to HFSC. Interestingly, DPSCs were positive for LRig1 and Blimp1, which are considered the main markers of HFSC. Thus, the comparative study of the expression of a broad panel of HFSC and DPSC stem cell markers suggests that cells isolated from both tissues may be potentially promising and increase the range of possibilities of their use in cell therapy and regenerative medicine.
\end{abstract}

Keywords: Stem cell. Hair follicle. Dental pulp. Markers of pluripotent stem cell. Immunohistochemistry. Immunofluorescence. 


\section{LISTA DE ILUSTRAÇÕES}

Figura 01 - Imagem ilustrativa de um fragmento de pele.................................... 28

Figura 02 - Corte transversal do bulbo piloso.................................................. 29

Figura 03 - Ciclo de vida do pelo................................................................... 30

Figura 04 - Representação esquemática das células tronco da unidade pilosebácea. 32

Figura 05 - Manutenção da pluripotência................................................................. 33

Figura 06 - Vibrissa e sua anatomia................................................................... 34

Figura 07 - Histórico dos trabalhos publicados sobre células tronco de polpa dentária.

Figura 08 - Histórico dos trabalhos publicados sobre células tronco de folículo piloso.

Figura 09 - Cortes histológicos da pele de focinho de camundongo corados por $\mathrm{H} \& \mathrm{E}$

Figura 10 - Cortes histológicos de epiderme de focinho de camundongo corados por HE e Masson.

Figura 11 - Cortes histológicos da mandíbula de camundongo corados por HE e Masson.

Figura 12 - Cortes histológicos da mandíbula de camundongo corados por HE

Figura 13 - Imunohistoquímica para Ckit em cortes histológicos de mandíbula e epiderme de focinho de camundongo C57BL6.

Figura 14 - Imunohistoquímica para Nestina em cortes histológicos de mandíbula e epiderme de focinho de camundongo C57BL6.

Figura 15 - Imunohistoquímica para Oct4, Nanog e Sox 2 em cortes histológicos de mandíbula e epiderme de focinho de camundongo C57BL6.

Figura 16 - Imunohistoquímica para CD73 em cortes histológicos de mandíbula e epiderme de focinho de camundongo C57BL6.

Figura 17 - Imunohistoquímica para CD90 em cortes histológicos de mandíbula e epiderme de focinho de camundongo C57BL6.

Figura 18 - Imunohistoquímica para CD105 em cortes histológicos de mandíbula e epiderme de focinho de camundongo C57BL6. 
Figura 19 - Imunohistoquímica para Integrina $\alpha 6$ em cortes histológicos de mandíbula e epiderme de focinho de camundongo C57BL6.

Figura 20 - Imunohistoquímica para Citoqueratina 15 em cortes histológicos de mandíbula e epiderme de focinho de camundongo C57BL6.....

Figura 21 - Imunohistoquímica para CD34 em cortes histológicos de mandíbula e epiderme de focinho de camundongo C57BL6.

Figura 22 - Imunohistoquímica para LGR5 em cortes histológicos de mandíbula e epiderme de focinho de camundongo C57BL6.

Figura 23 - Imunohistoquímica para LGR6 em cortes histológicos de mandíbula e epiderme de focinho de camundongo C57BL6.

Figura 24 - Imunohistoquímica para LRig1 em cortes histológicos de mandíbula e epiderme de focinho de camundongo C57BL6.

Figura 25 - Imunohistoquímica para Blimp1 em cortes histológicos de mandíbula e epiderme de focinho de camundongo C57BL6.

Figura 26 - Métodos de isolamento utilizados para obtenção de células da vibrissa..

Figura 27 - Diferentes morfologias celulares derivadas do cultivo celular da vibrissa pelo método de "explante" e meio Low glicose.

Figura 28 - Diferentes morfologias celulares derivadas do cultivo celular da vibrissa pelo método de "explante" com o meio de cultivo DMEM-F12.

Figura 29 - Diferentes morfologias celulares derivadas do cultivo celular da vibrissa pelo método de "explante" e com o meio de cultivo para IPSC e neurobasal.

Figura 30 - Cultivo primário da polpa dentária de camundongo e as diferentes morfologias celulares derivadas do explante do tecido mantida no meio DMEM-12 na passagem $1(\mathrm{P} 1)$...

Figura 31 - Imunofluorescência e citometria de fluxo para CKit.

Figura 32 - Imunofluorescência e citometria de fluxo para Nestina.....

Figura 33 - Imunofluorescência e citometria de fluxo para Oct4

Figura 34 - Imunofluorescência e citometria de fluxo para Nanog.

Figura 35 - Imunofluorescência e citometria de fluxo para Sox 2.

Figura 36 - Imunofluorescência e citometria de fluxo para CD73.

Figura 37 - Imunofluorescência e citometria de fluxo para CD90. 
Figura 38 - Imunofluorescência e citometria de fluxo para CD105........................ 82

Figura 39 - Imunofluorescência e citometria de fluxo para Integrina $\alpha 6 \ldots \ldots \ldots \ldots \ldots \ldots . . . . . . .83$

Figura 40 - Imunofluorescência e citometria de fluxo para Citoqueratina $15 \ldots \ldots \ldots \ldots . . \quad 84$

Figura 41 - Imunofluorescência e citometria de fluxo para CD34.......................... 85

Figura 42 - Imunofluorescência e citometria de fluxo para LGR5 ........................ 86

Figura 43 - Imunofluorescência e citometria de fluxo para LGR6 ....................... 87

Figura 44 - Imunofluorescência e citometria de fluxo para LRig1 ......................... 88

Figura 45 - Imunofluorescência e citometria de fluxo para Blimp1 ........................ 89

Figura 46 - Eletroforese em gel de agarose 1,2\% do cDNA a partir do lisado celular das culturas de vibrissa e polpa dentária. 


\section{LISTA DE TABELAS}

Tabela 1 - Meios utilizados para o cultivo de vibrissa....................................... 45

Tabela 2 - Células utilizadas para caracterização................................................. 71

Tabela 3 - Compilação dos resultados obtidos nas imunomarcações e PCR........... 91

Tabela 4 - Anticorpos utilizados................................................................. 123

Tabela 5 - Primers utilizados....................................................................... 104 


\title{
LISTA DE ABREVIATURAS E SIGLAS
}

\author{
Blimp1 B lymphocyte-induced maturation protein-1 \\ BrdU Bromodeoxeuridina \\ BSA Bovine serum albumin (albumina bovina) \\ CD14 Co-receptor para lipopolisacarídeos bacterianos (LPS) \\ CD34 Glicoproteína de membrana abundante em células tronco hematopoiéticas \\ CD45 Antígeno expresso em células hematopoiéticas \\ CD73 Proteína de membrana com ação enzimática e de adesão \\ CD90 Proteína de membrana com função de adesão \\ CD105 Glicoproteína integral de membrana associada à receptores TGF $\beta$ \\ CKit Receptor tirosina quinase presente em células tronco derivadas da crista neural \\ CT Células tronco \\ CTA Células tronco adulta \\ CTB Células tronco do bulge \\ CTE Células tronco embrionária \\ CTH Células tronco hematopoiética \\ CTM Células tronco mesenquimal \\ CTIPD Células tronco imatura da polpa dentária \\ CTPD Células tronco da polpa dentária \\ CTV Células tronco das vibrissas \\ DAPI 4',6-Diamidino-2-phenylindol \\ DMEM F12 Dulbecco's Modified Eagle Medium (meio para cultura de células) \\ $\mathrm{Fz} \quad$ Receptor Frizzled \\ GAPDH gliceraldeído-3-fosfato desidrogenase, enzima da via da glicólise. \\ GFAP Proteína glial fibrilar ácida \\ iPS Induced pluripotent stem cell (células tronco pluripotente induzidas) \\ Klf4 Kruppel-like factor 4 (fator de transcrição de células tronco embrionárias) \\ LGR5 Leucine-rich repeat-containing G-protein coupled receptor 5 \\ LGR6 Leucine-rich repeat-containing G-protein coupled receptor 6 \\ LIF leukaemia inhibitory fator (fator inibidor de leucemia) \\ MEF Mouse embryo fibroblast (fibroblasto de embrião de camundongo) \\ Myc Fator de transcrição
}


Nanog Fator de transcrição codificado pelo gene NANOG homeobox

Nestina Filamento intermediário expresso em células neurais

Oct4 Fator de transcrição codificado pelo gene POU5F1

P75 Receptor para fatores de crescimento

PBS Phosphate buffer solution (solução tampão de fosfato)

PC12 Pheochromocytoma cells

PcG Polycomb group (são reguladores epigenéticos)

RT-PCR Reação em cadeia da polimerase antecedida por uma transcriptase reversa

SFB Soro fetal bovino

SH2 Proteína de domínio presente em células tronco embrionárias

SH3 Proteína de domínio presente em células tronco embrionárias

SH4 Proteína de domínio presente em células tronco embrionárias

SKPs $\quad$ Skin derivated progenitor (progenitores derivados da pele)

Slug Fator de transcrição

Snail Fator de transcrição

Sox2 Fator de transcrição (Sex determining region $Y-$ box2)

Sox9 Fator de transcrição

Sox10 Fator de transcrição

SSEA-3 Proteína presente em células tronco embrionárias

SSEA-4 Proteína presente em células tronco embrionárias

TRA1-60 Proteína presente em células tronco embrionárias

TRA1-80 Proteína presente em células tronco embrionárias

Twist Fator de transcrição 


\section{SUMÁRIO}

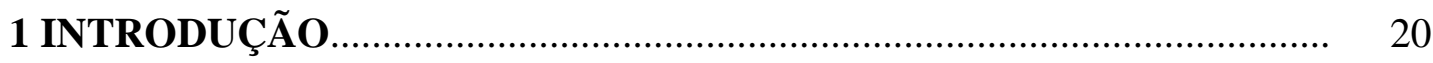

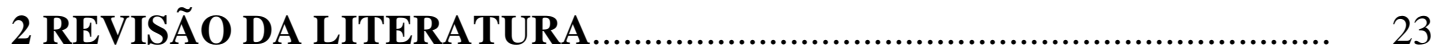

2.1 Células tronco

2.1.1 Células tronco embrionárias....................................................................... 24

2.1.2 Células tronco pluripotentes induzidas................................................... 25

2.1.3 Células tronco adultas.............................................................................. 26

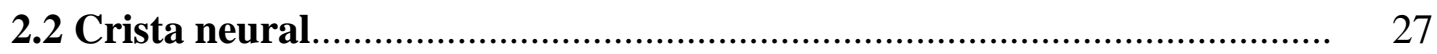

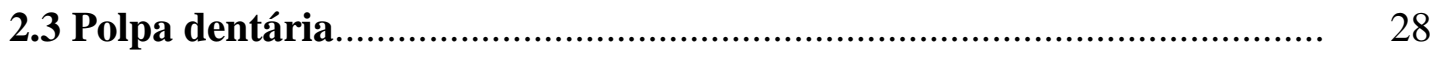

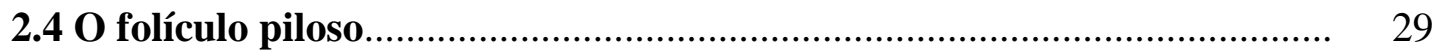

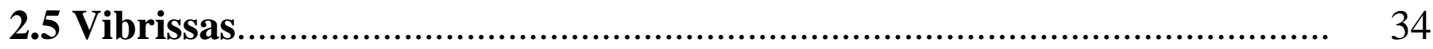



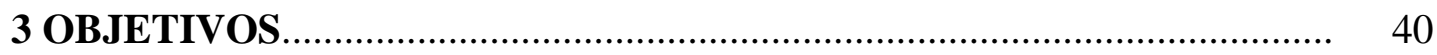



3.2 Objetivos específicos...................................................................... 42

4 MATERIAL E MÉTODOS ............................................................... 42

4.1 Fixação e inclusão de material biológico em parafina............................. 42

4.1.1 Coloração por hematoxilina - eosina ...................................................... 42

4.1.2 Ensaio de imunohistoquímica................................................................ 43

4.2 Obtenção e estabelecimento de cultura primária da unidade pilosebácea e polpa dentária de camundongos C57BL-6.............................. 43

4.3 Determinação do meio para cultivo primário de células isoladas de vibrissas e polpa dentária

4.4 Imunofluorescência. 


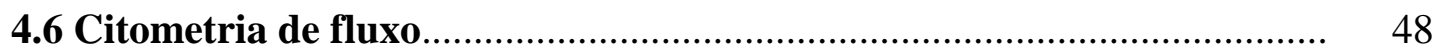

5 RESULTADOS

5.1 Caracterização ex vivo de marcadores imunofenotípicos para células tronco na vibrissa e polpa dentária utilizando o método de imunohistoquímica.

5.2 Obtenção celular a partir da cultura primária de vibrissas e caracterização fenotípica das células isoladas in vitro quanto ao método de isolamento.

5.3 Determinação do meio para cultivo primário de vibrissas.

5.4 Obtenção celular a partir da polpa dentária e caracterização fenotípica das células isoladas in vitro.

5.5 Caracterização in vitro da expressão de marcadores imunofenotípicos para células tronco de vibrissa e polpa dentária utilizando os métodos de imunofluorescência e citometria de fluxo

5.6 PCR...

6 DISCUSSÃO.

7 CONCLUSÃO.

REFERÊNCIAS

A - Fixação e inclusão de material biológico em parafina.

B - Coloração por hematoxilina - eosina...

C - Protocolo de imunohistoquímica com fosfatase alcalina.

ANEXOS.

A - Tabela de anticorpos.

B -Tabela de primers. 
INTRODUÇÃO 


\section{INTRODUÇÃO}

Os nichos de células tronco se formam durante a vida fetal e se mantêm ativos ao longo da vida pós-natal servindo de reservatório para o reparo e remodelamento de qualquer tecido (KLIMCZAK; KOZLOWSKA, 2016). Em seus nichos estas células permanecem em estado quiescente, porém quando necessário são autorrenovadas e podem se diferenciar nos diferentes tipos celulares durante os processos de reparação tecidual como acontece em órgãos como fígado, pâncreas, medula óssea, pele, dente e outros (KLIMCZAK; KOZLOWSKA, 2016).

Dentre os muitos tecidos estudados como fonte de células tronco adultas (CTA), polpa dentária e folículos pilosos têm se destacado nos últimos anos por serem um reservatório de fácil acesso, que fornece boas quantidades de células quando em cultura e não esbarram em nenhum preceito ético ou legal.

Por serem de origem embrionária da crista neural, uma população de células multipotentes que contribui durante o desenvolvimento para a formação de ossos, cartilagem e tecido conectivo da face, neurônios e células da glia do sistema nervoso periférico, células de pigmentação da pele e, em algumas regiões do sistema cardio vascular, mesênquima e células de músculo liso, estes dois tecidos compartilham a expressão de alguns marcadores como, por exemplo, Oct4, Nanog e Sox2 que são fatores de transcrição e característicos de células tronco embrionárias (CTE) (DRISKELL et al., 2009; YU et al., 2006). Além disso, sendo isoladas dos tecidos adultos cumprem os critérios mínimos de classificação para células tronco mesenquimais (CTM) apresentando positividade para CD73, CD90 e CD105 além de serem aderentes ao plástico e se diferenciarem em condrócitos, adipócitos e osteócitos (DOMINICI et al., 2006). Apresentam marcação para Nestina (VRAPCIU; RUSU; VOINEA, 2014), evidenciando um potencial para diferenciação neurogênica, como também podem expressar CD34 (TREMPUS et al., 2003), um conhecido marcador de células tronco hematopoiéticas $(\mathrm{CTH})$. Possuem também positividade para LGR5 e LGR6 que são marcadores relacionados à epiderme (BARKER; CLEVERS, 2010; KAWASAKI et al., 2014; KIM et al., 2014).

Diante de uma variedade tão grande de marcadores expressos, é comum que polpa dentária e vibrissa sejam utilizadas como fonte de células para terapêutica, medicina regenerativa e fonte de células para produção de células tronco pluripotente induzidas (iPS). Células da polpa dentária podem ser utilizadas para regeneração do dente, osso, no tratamento 
da diabetes, ou estimular angiogênese (KERKIS; CAPLAN, 2012; TATULLO et al., 2015), enquanto que células de folículo já foram utilizadas para restaurar in vivo nervos de camundongo (AMOH et al., 2009) e reparar in vivo lesões na córnea de camundongos (BLAZEJEWSKA et al., 2011).

Mesmo com essa grande versatilidade destes dois tecidos e tantas pesquisas realizadas ainda não se tem um quadro completo do seu potencial. Desta forma, a aplicação de um painel mais amplo de marcadores, preferencialmente expressos nas vibrissas, mas desconhecido na polpa dentária precisa ser testado. 
REVISÃO DA LITERATURA 


\section{REVISÃO DA LITERATURA}

\subsection{Células tronco}

As células tronco (CT) são definidas como células indiferenciadas e não especializadas com grande capacidade de autorrenovação. São capazes de se multiplicar e originar uma grande população de células semelhantes mantendo-se indiferenciadas e quando necessário podem se diferenciar em células especializadas (KERKIS et al., 2006).

Por apresentarem estas características, as CT possuem um grande potencial de aplicabilidade terapêutica, como por exemplo, em doenças osteoarticulares, neurodegenerativas e na regeneração tecidual da pele (TATULLO et al., 2015; WU et al., 2006)

As CT são classificadas quanto ao seu potencial de diferenciação em:

Totipotentes - são capazes de se diferenciar em todos os tipos celulares do organismo, inclusive os anexos placentários. O único exemplo de célula totipotente é o zigoto;

Pluripotentes - são capazes de se diferenciar em todos os tipos celulares derivados dos três folhetos germinativos (endoderma, mesoderma e ectoderma) (THOMSON et al., 1998), porém não são capazes de criar um organismo adulto, pois não derivam os anexos placentários, como as células totipotentes. As células tronco embrionárias e células tronco pluripotente induzidas são exemplos de células pluripotentes.

Multipotentes - são células com potencial de diferenciação mais restrito que as pluripotentes. Em geral, derivam um tipo celular do folheto embrionário, cujo potencial de diferenciação varia de acordo com seu tecido de origem, como por exemplo, células tronco mesênquimais.

Estas células também podem ser classificadas de acordo com sua origem:

Células tronco embrionárias (CTE) - derivadas da massa celular interna do blastocisto.

Células tronco pluripotentes induzidas (iPS - do inglês "induced pluripotent stem cells") - são células adultas reprogramadas através da inserção de fatores de transcrição específicos, promovendo a pluripotência, tornando-se similares às células tronco embrionárias. 
Células tronco fetais - são as células tronco pós-natais, tais como as células isoladas de cordão umbilical, feto (material abortivo), placenta, entre outras. São consideradas células tronco adultas (CTA), porém apresentam maior potencial de diferenciação (CARLIN et al., 2006).

Células tronco adultas - tecido-específicas isoladas de medula óssea, pele, gordura, músculo, polpa dentária, entre outras.

\subsubsection{Células tronco embrionárias.}

As CTE foram isoladas pela primeira vez em 1981, a partir de blastocistos de camundongos, sendo um dos maiores acontecimentos no campo do desenvolvimento biológico (EVANS, 1989, 1998; MARTIN, 1981).

Na pesquisa básica, as CTE são geradas com o objetivo de estudar os mecanismos de diferenciação celular, bem como investigar seu potencial terapêutico em diferentes modelos experimentais. As CTE, in vitro, são cultivadas sobre uma camada de fibroblastos embrionários de camundongo (MEF - do inglês "mouse embryo fibroblast") mitoticamente inativados (WILLIAMS et al., 1988) e se mantém em estado indiferenciado na presença do fator inibidor de leucemia (LIF - do inglês "leukaemia inhibitory fator") (CLARKE et al., 2006). Atualmente, há estudos com linhagens de CTE de camundongos, coelhos, porcos e primatas (EVANS, 1989; GRAVES et al., 1993; LI et al., 2003; MARTIN, 1981; THOMSON et al., 1995, 1998).

O processo de diferenciação celular a partir das CTE in vitro é realizado utilizando meios de cultivo com indutores apropriados para cada linhagem celular. A primeira etapa da diferenciação celular consiste na formação de um agregado celular que é denominado de corpo embrióide, que é realizado pela técnica de "hanging drop". Esta estrutura contém todos os tipos celulares do organismo como cardiomiócitos, oligodendrócitos, astrócitos, células beta do pâncreas e células hepáticas (SACHINIDIS et al., 2003).

O estado de pluripotência de uma célula tronco embrionária é regulado por uma complexa rede de fatores de transcrição tais como oct4, nanog, sox2, Myc e outros (THOMSON et al., 2011) que mantêm estas células em um estado de indiferenciação tão primordial que elas podem dar origem a todos os tipos de tecidos adultos (GRINNELL et al., 
2007). Quando injetadas em camundongos imunodeficientes, estas geram teratomas constituídos de células de todos os três folhetos germinativos (MATSU-URA et al., 2016).

Experimentos conduzidos em camundongos utilizando as CTE como tratamento para lesões no miocárdio são bastante promissores (DELCARPIO et al., 1995; KOH et al., 1993, 1995; ROELL et al., 2002). Doenças degenerativas ou doenças associadas com a perda de função das células como, por exemplo, a diabetes também podem ser tratadas com a utilização de CTE (KONAGAYA; IWATA et al., 2016). Neste tratamento é esperado que órgãos e tecidos desempenhem sua função melhor do que quando tratados com fármacos ou transplantes. No entanto, as células tronco embrionárias apresentam questionamentos éticos quanto a sua utilização na pesquisa básica e aplicada. Desta forma, fontes alternativas de células pluripotentes foram reproduzidas, como as iPS.

\subsubsection{Células tronco pluripotentes induzidas.}

As células tronco pluripotentes induzidas (iPS) são células adultas geneticamente modificadas e reprogramadas, que ao final de um processo de transfecção tornam-se similares às células embrionárias (BELTRÃO-BRAGA et al., 2011; TAKAHASHI; YAMANAKA, 2006). As primeiras iPS foram obtidas em 2006 por Takahashi e Yamanaka com o objetivo de desenvolver uma fonte alternativa de células pluripotentes. As iPS foram derivadas de fibroblastos embrionários de camundongos infectados com vetores retrovirais que quando transcritos e traduzidos expressariam fatores como Oct3/4, Sox2, c-Myc e Klf4, gerando assim, células semelhantes às embrionárias em relação à morfologia, fenótipo e funcionalidade (AMABILE, 2009; YU, 2008).

Ainda, as iPS podem ser utilizadas para estudos genéticos. Isso foi observado em 2009 por Ebert e colaboradores que derivaram iPS de pacientes diagnosticados com atrofia muscular espinhal e posteriormente induziram essas células a se diferenciarem em neurônios motores. Eles demonstraram que os neurônios motores do indivíduo afetado apresentavam baixos níveis de sobrevivência quando comparados a neurônios derivados de iPS obtidas de um paciente não afetado.

Apesar de seu grande potencial, as iPS são de difícil obtenção. A melhor eficiência reportada em trabalhos publicados foi de $0,1 \%$, por Huangfu e colaboradores (2008). Além disso, os fibroblastos são células terminalmente diferenciadas e não ideais para futura terapia 
celular devido ao acúmulo de danos ao DNA causados pela luz solar, o que aumenta as chances de desenvolvimento tumoral nessas células (MUOTRI et al., 2002). Outro problema também observado foi à dificuldade de controlar a sua diferenciação in vivo, sendo que esse risco pode ainda ser maior quando a reprogramação for efetuada sob ação retroviral (TAKAHASHI; YAMANAKA, 2006).

Atualmente, a extensa investigação sobre as células tronco pluripotentes, por apresentarem capacidade de derivar todas as células do organismo, vem sendo considerada uma poderosa ferramenta de pesquisa (HOLLAND, 2005). No entanto, o seu potencial teratogênico, a falta de esclarecimento sobre os mecanismos de diferenciação, o alto custo para isolamento e expansão que é exigido na produção destas células são fatores que restringem o seu uso terapêutico. Desta forma, as CTA são consideradas uma fonte terapêutica mais apropriada, principalmente por não apresentarem questionamento ético quanto ao seu uso em pesquisa, não serem teratogênicas e por serem consideradas células imunocompatíveis. E uma promissora fonte de tecidos para transplante (ASAHARA et al., 2000; BUENO et al., 2009; FODOR, 2003; KERKIS et al., 2008; MONTEIRO et al., 2009; WATERS, 2007).

\subsubsection{Células tronco adultas.}

As CTA são células indiferenciadas presentes nos tecidos de indivíduo adulto como, por exemplo, cérebro, medula óssea, sangue periférico, sistema digestivo, rim, pâncreas, retina, músculo, fígado, pele, polpa dentária, placenta, encéfalo e outros (KERKIS et al., 2006; SLACK, 2000; TARNOWSKI, 2006). Nos tecidos adultos estas células são responsáveis pela manutenção dos mesmos através do reparo tecidual (MINGUELL; CONGET; ERICES, 2000; PITTENGER et al., 1999).

Inicialmente, acreditou-se que as CTA fossem comprometidas a uma ou a poucas linhagens e estivessem envolvidas apenas na reparação dos mesmos, e que fossem incapazes de serem reprogramadas em uma célula para se diferenciar em outros tecidos, entretanto, sugerem que a diferenciação inicial de uma via específica não é irreversível (POULSOM et al., 2002). As CTA podem se diferenciar em vários tecidos, porém com um pouco mais de restrição, pois são multipotentes. Todavia elas não apresentam problemas éticos, possuem uma diferenciação mais controlada e não são teratogênicas quando comparadas às CTE. 
A medula óssea, o tecido adiposo e a polpa dentária são fontes de CT comumente estudadas. Estas fontes são ricas em CTM e possuem células que diferem entre si quanto ao seu potencial de diferenciação e expressão de marcadores (AGHAJANI et al., 2016; JENSEN et al., 2016; NIADA et al., 2016). Por apresentar uma grande quantidade de marcadores, a Sociedade Internacional para Terapia Celular propôs critérios mínimos para definir uma CTM. Estas células devem ser aderentes ao plástico; devem ser positivas para os marcadores CD73, CD90 e CD105, e ser negativas para CD14, CD34 e CD45; e devem ter a habilidade de se diferenciar in vitro em condrócitos, osteoblastos e adipócitos (DOMINICI et al., 2006).

\subsection{Crista neural}

A crista neural emerge como um tecido transiente derivado do mesoderma e do ectoderma durante o desenvolvimento do feto, do qual migram células para várias regiões do embrião que se transformam em diversos tipos celulares específicos como, por exemplo, células do músculo liso, neurônios periféricos, células da glia, células pigmentares, condroblastos, osteoblastos e odontoblastos (KREJCI; GRIM, 2010).

Células derivadas da crista neural podem ser localizadas em tecidos adultos com marcadores específicos, como acontece com o CKit (HATZISTERGOS et al., 2015). O padrão $\mathrm{CKit}^{+}$pode ser encontrado em progenitores cardíacos (HATZISTERGOS et al., 2015), células da epiderme (KREJCI; GRIM, 2010; POTTEN; BOOTH, 2002), na papila dermal de pelos e vibrissas, folículos e bulge (WONG et al., 2006) e polpa dentária (PISCIOTTA et al., 2015).

Por ser uma célula da crista neural, as células $\mathrm{CKit}^{+}$são consideradas células tronco, uma vez que elas podem ser induzidas a se diferenciarem em diferentes tipos celulares. Pisciotta et al, 2015 demonstrou que células $\mathrm{CKit}^{+}$da polpa dentária são capazes de originar células das linhagens miogênica, adipogênica e osteogênica. Células da polpa dentária também podem ser utilizadas para terapia e regeneração de outros tecidos como reparo de dente, ossos, lesões neurológicas, isquemias (angiogênese) e no tratamento de doenças degenerativas de glândulas como as do fígado e pâncreas (TATULLO et al., 2015). Já o bulge de pelos e vibrissas possui uma população de células derivadas da crista neural com potencial para diferenciação in vitro em neurônios, glia, queratinócitos, células do músculo liso e 
melanócitos (AMOH et al., 2009). Amoh et al, 2009 demonstrou que células do bulge CD34 ${ }^{+}$ e Nestina ${ }^{+}$são capazes de regenerar e restaurar a função de nervos lesionados.

Além dos marcadores Nestina, CD34 e CKit, a polpa dentária compartilha outros marcadores de células tronco do bulge como, por exemplo, LGR5 (KIM et al., 2014) e LGR6 (KAWASAKI et al., 2014) que são expressos na porção epitelial do dente.

\subsection{Polpa dentária}

Dentre as fontes de células tronco adultas, a polpa dentária se destaca por ser uma fonte com grande quantidade de células tronco que são facilmente obtidas de dente decíduo (dente de leite) (KERKIS et al., 2006).

A polpa de dente decíduo é derivada da crista neural durante a odontogênese e esta contribui na formação do dente com células originadas de dois folhetos embrionários, o mesoderma e o ectoderma. Estas células dão origem a todos os componentes do dente, com exceção do esmalte, e também são precursoras da maioria dos tecidos conjuntivos e ossos do crânio (MILETICH; SHARPE, 2004). A polpa dentária apresenta um perfil de tecido conectivo vascular semelhante ao encontrado em alguns tecidos mesenquimais como medula óssea, placenta, músculo e adipócitos (CHENG, 2008).

As células tronco da polpa dentária (CTPD) possuem morfologia fibroblastóide in vitro e expressam os principais marcadores das CTM, como SH2, SH3 e o SH4 (JIANG et al., 2002), também expressam marcadores neuronais como Nestina e GFAP (KERKIS et al., 2006). Adicionalmente, células isoladas por Kerkis e colaboradores (2006) apresentaram uma população de células positivas para os fatores de transcrição Nanog, Oct4 e Sox2, que são típicos de células tronco pluripotentes, sendo então denominadas como "Células tronco Imaturas de Polpa Dentária" (CTIPD). Além destes marcadores, expressam também um grupo de antígenos estágios-específicos de superfície celular (SSEA-3 e SSEA-4) e fatores de transcrição TRA1-60 e TRA1-80 que são expressos em CTE (LASLETT et al., 2003).

Apesar de expressarem os principais marcadores de pluripotência, as CTIPD não produzem tumores quando injetadas in vivo e por isso podem ser utilizadas terapeuticamente. Em modelos animais ou in vitro são capazes de formar tecidos maduros como osso, músculo e epitélio corneano, sem a necessidade de imunossuprimir o modelo animal, pois apresentam 
baixa imunogenicidade (GOMES et al., 2010; KERKIS et al., 2008; MENDONÇA COSTA et al., 2008). Estas células também são capazes de contribuir na formação de tecidos fetais em quimeras humano/camundongo sugerindo que de fato estas células têm a capacidade de colaborar significativamente durante o desenvolvimento embrionário (FONSECA et al., 2009). Na figura 7 é apresentado um breve histórico onde encontram-se alguns dos muitos trabalhos publicados sobre CT extraídas de polpa dentária.

\subsection{O folículo piloso}

Outra fonte de células tronco, que assim como a polpa dentária possui origem da crista neural são os folículos pilosos como o pelo e a vibrissa. $\mathrm{O}$ folículo piloso é uma estrutura dérmica complexa composta por bulbo, glândula sebácea, a saliência do bulge, pelo e papila dermal (figura 1). Somente papila dermal possui origem mesodérmica, sendo que os restantes das estruturas são de origem ectodérmica (LI et al., 2014).

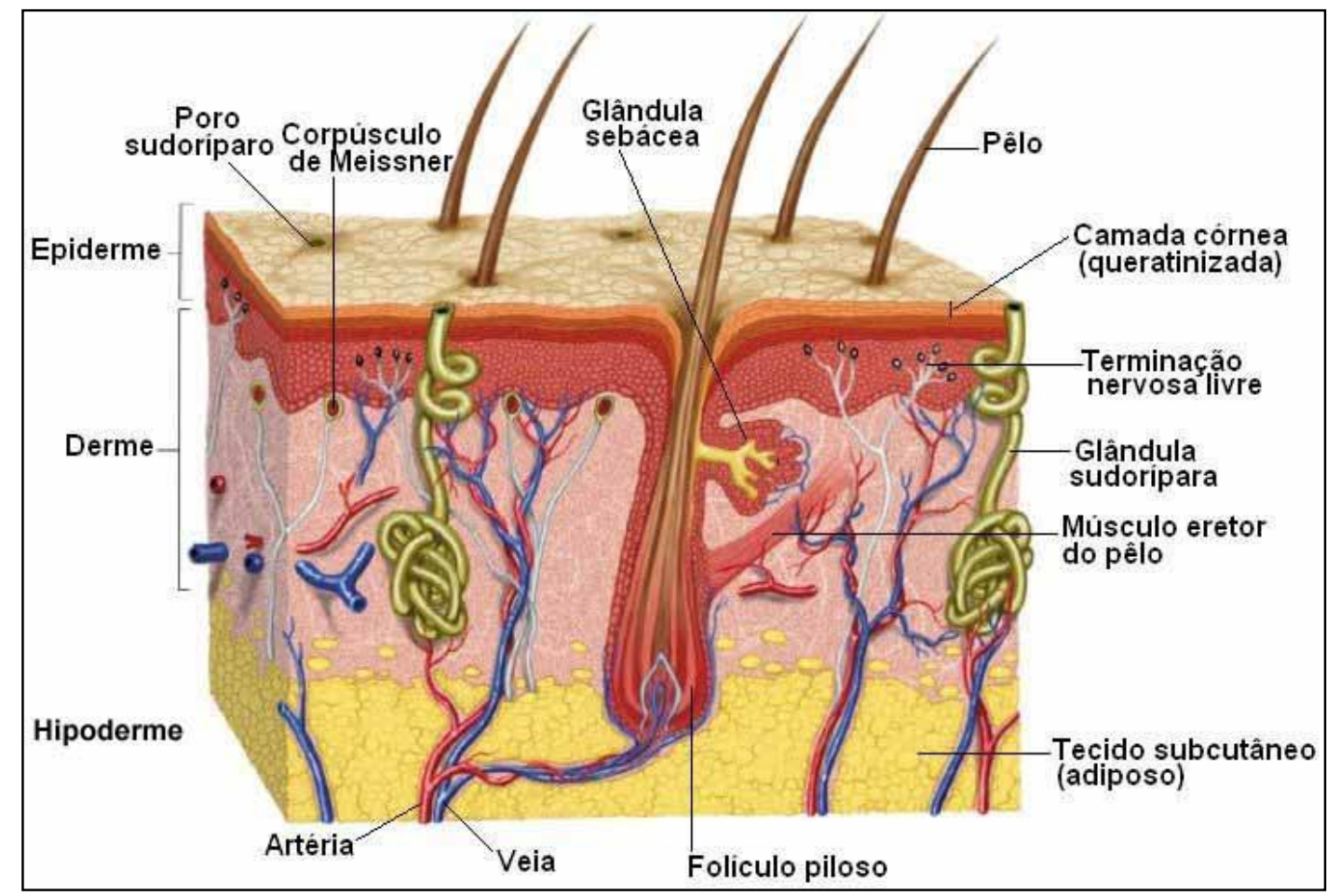

Figura 1 - Imagem ilustrativa de um fragmento de pele. Notar as três camadas da pele (epiderme, derme e hipoderme) e seus principais anexos.

Fonte: http://www.sobiologia.com.br/figuras/Reinos3/epiderme.gif 
O pelo é uma estrutura delgada formada de sucessivas camadas de células queratinizadas (figura 2) que possui algumas funções como proteção contra traumas, insetos e radiação; também pode servir como 'antena' sensorial para sentir o ambiente além de poder ser utilizado como camuflagem ou decoração (STENN; PAUS, 2001).

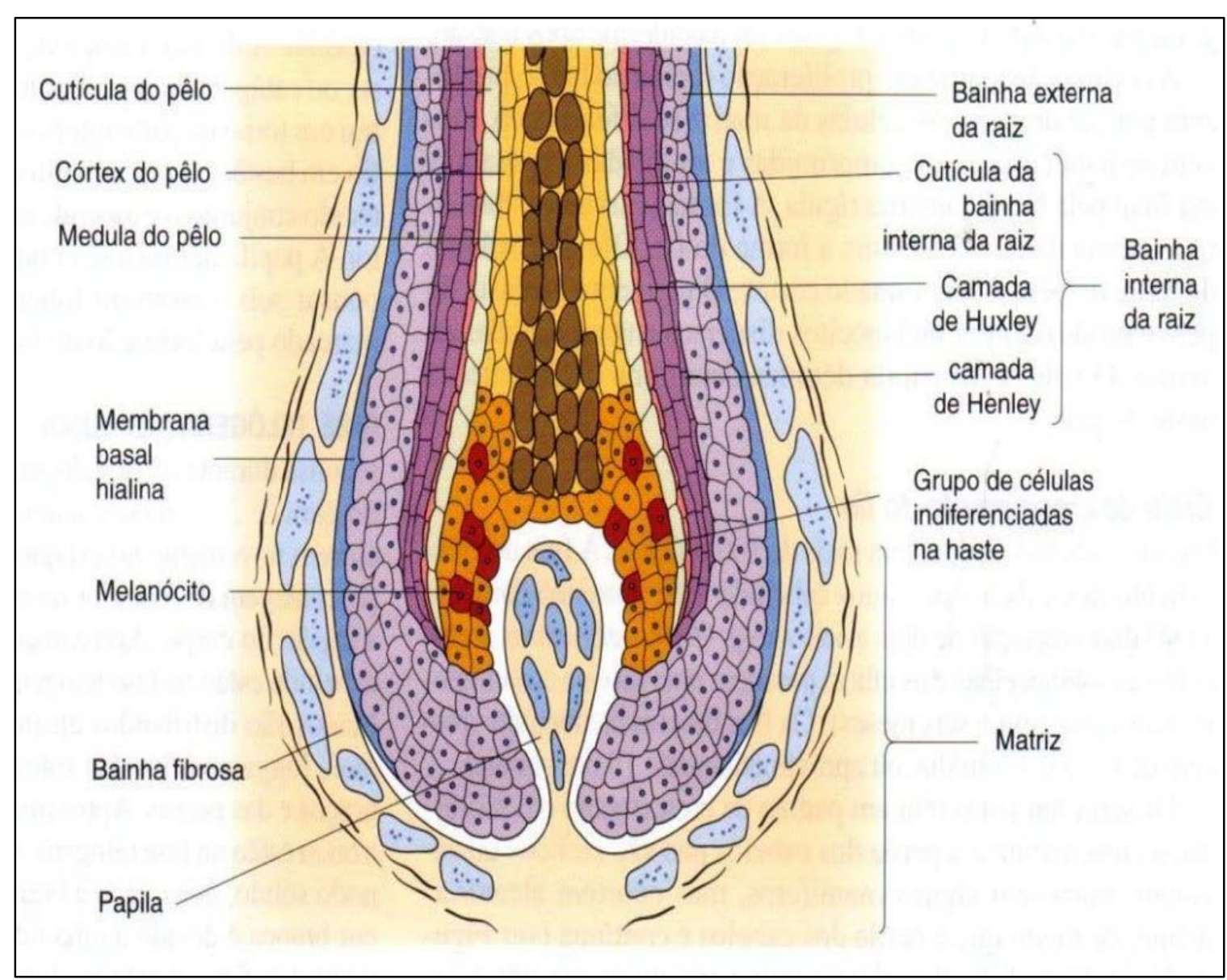

Figura 2 - Corte transversal do bulbo piloso.

Fonte: (HABIF, 2005)

A papila folicular (ou papila dermal) é uma região de intensa proliferação celular na qual se encontram fibroblastos especializados que atuam sobre a regulação do ciclo capilar (LI et al., 2014; YANG; COTSARELIS, 2010). A medula é composta de queratinócitos pouco cornificados e vacuolizados e é envolvida por um córtex de células pigmentadas dispostas em forma de escamas abundantemente queratinizadas. As bainhas (interna e externa) envolvem o pelo e o acompanham até a altura da glândula sebácea (interna) e até a camada basal da epiderme (externa) (JUNQUEIRA; CARNEIRO, 2004).

No folículo piloso, as células tronco estão localizadas no bulge, que é um discreto microambiente também conhecido como saliência do folículo piloso. O bulge é localizado na região medial do folículo, estabelecida durante a morfogênese e que não se degenera durante o ciclo do fio. Nesta estrutura encontra-se uma complexa população de células 
multi/pluripotentes das quais podemos citar as células tronco dos queratinócitos, células tronco pluripotentes da crista neural e as células tronco de linhagem melanogênica, todas encontradas na região do bulbo (BLUM et al., 2004). As células tronco do bulge são mais quiescentes que as outras células do folículo. No entanto, durante o ciclo do fio, estas células são estimuladas a sair do seu nicho, proliferar e se diferenciar formando os vários tipos celulares maduros do folículo piloso.

Segundo Ito 2007, o ser humano nasce com uma quantidade fixa de folículos que ao longo da vida produz o pelo num processo de crescimento cíclico com fases de crescimento (anágena), regressão (catágena), repouso (telógena) e queda (exógena) (figura 3).



Figura 3 - Ciclo de vida do pelo. Crescimento (anágena), regressão (catágena), repouso (telógena) e queda (exógena).

Fonte: Adaptado de http://wp.clicrbs.com.br/falandosc/files/2011/01/pelos1.jpg

Na fase anágena do ciclo do pelo ocorre uma migração das células tronco do bulge (CTB) (bulge stem cells) localizada logo abaixo da glândula sebácea, para a matriz. Este deslocamento de células ocorre devido ao contato do segundo germe e papila dermal com o bulge devido à retração do folículo na fase catágena. As células do bulge então repovoam a matriz e se diferenciam em sete diferentes linhagens celulares que irão formar as quatro camadas do pelo e as três camadas da bainha interna. Esta fase de proliferação celular varia de 
acordo com o fio em questão, por exemplo, o pelo de camundongos e os pelos das sobrancelhas de humanos permanecem entre duas a quatro semanas enquanto que os fios do couro cabeludo de humanos ficam em anágena por anos (COTSARELIS, 2006).

As células do bulge são extremamente versáteis. Segundo Cotsarelis 2006, esta é uma região da unidade pilosebácea com uma mistura de células tronco de queratinócitos, CT de melanócitos e células de Langerhans imaturas de baixo índice de divisão celular e que são capazes de reter marcadores análogos a nucleotídeos como, por exemplo, o bromodeoxeuridina (BrdU) e desta forma são conhecidas como células retentoras de marcação (do inglês, label-retaining cells). Elas contribuem na reposição de toda a linhagem celular do folículo e atuam também nos processos de cicatrização da pele devido aos diferentes fatores de transcrição e receptores expressos em suas membranas.

As células tronco do bulge são identificadas principalmente pela expressão do marcador de superfície celular CD34, das citoqueratinas 15 e 19 (CK15 e CK19) e integrina$\alpha 6$ (TREMPUS et al., 2003; ZHANG et al., 2010), e a expressão destes marcadores caracterizam as células como mais indiferenciadas (LIU et al., 2003).

O receptor de membra CD34 é expresso somente nas células do bulge, desta forma pode ser usado para diferenciar estas células das demais regiões do folículo piloso. Outro grupo de células do bulge expressa um receptor transmembrana de sete domínios chamado LGR5 que trabalha junto do receptor Frizzled (Fz) ativando a via de sinalização canônica do gene Wnt. Os receptores LGR5 estão expressos nas células progenitoras do folículo piloso que irão compor a matriz (CARMON et al., 2012; PLIKUS et al., 2012). Células multipotente CD34/LGR6 ${ }^{+}$atuam principalmente na manutenção da glândula sebácea e da pele promovendo até a reepitelização da epiderme interfolicular (BOEHNKE, 2012).

Na porção do istmo do folículo, outro grupo apresenta o padrão CD34/BLIMP1 ${ }^{+}$que na literatura é dito como células progenitoras de sebócitos, porém Kretzschmar et al, 2014, sugerem que o marcador BLIMP1 é na verdade um indicador de diferenciação terminal dos sebócitos que mesmo na fase terminal de diferenciação ainda contribuem para a homeostase da unidade pilosebácea e pele. Ainda no istmo, têm-se as células tronco bipotentes de perfil $\mathrm{CD} 4^{+} / \mathrm{LRIG}^{+}$que contribuem com as linhagens de células do infundíbulo e da glândula sebácea (PLIKUS et al., 2012) (figura 4). 
Além do bulge, a região da papila também agrupa uma subpopulação de células tronco. Estas células são derivadas da crista neural e são denominadas como progenitores derivados de pele (skin derivated progenitor ou SKPs) que expressam os fatores de transcrição característicos da crista neural, como Sox2, Snail, Slug, Twist e apresentam potencialidade para diferenciação em células dermais e neurais (BLANPAIN; FUCHS, 2009).

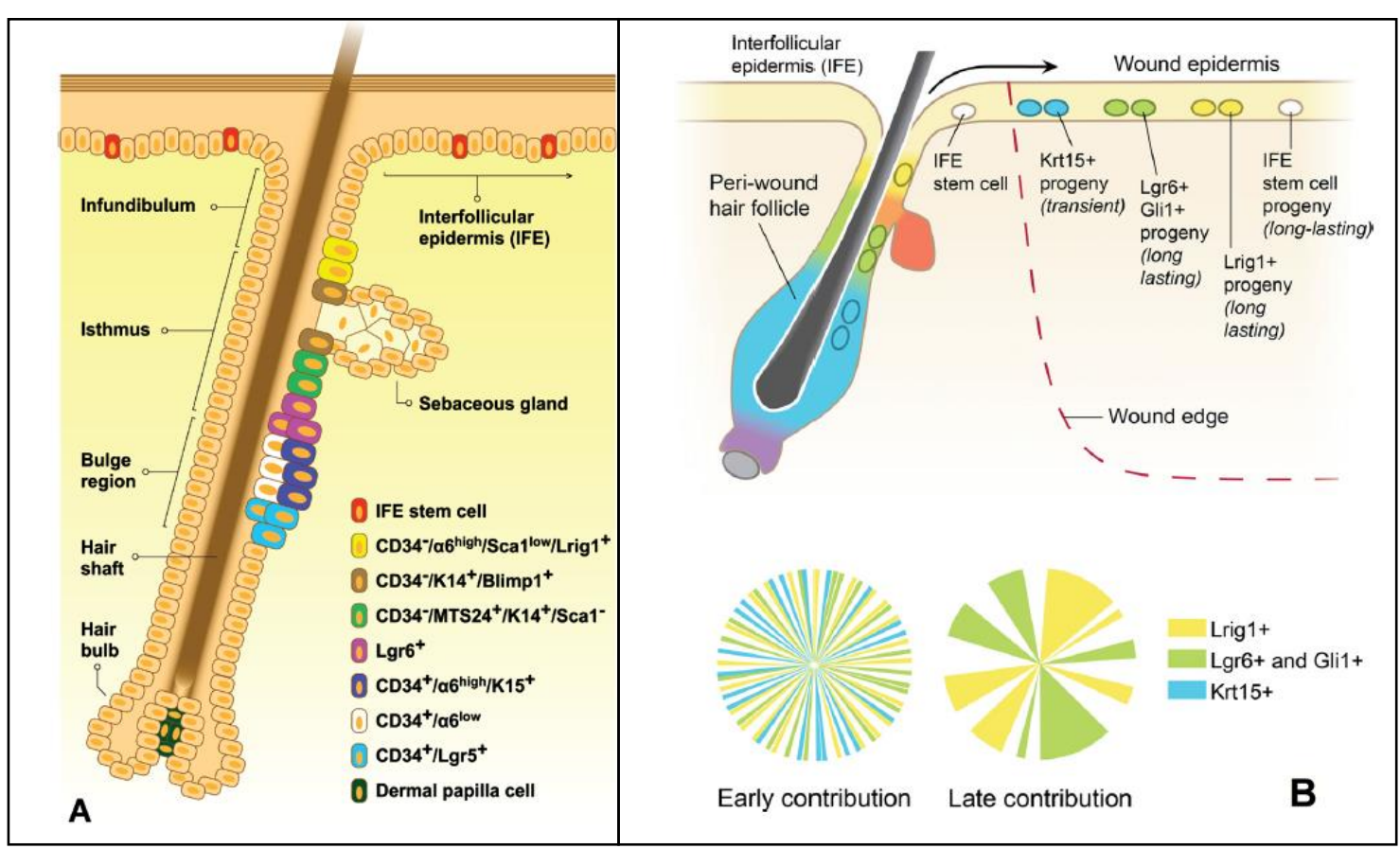

Figura 4 - Em (A) Representação esquemática das células tronco da unidade pilosebácea. Adaptado de Boehnke et al., 2012. (B) Contribuição das células tronco da unidade pilosebácea no reparo da epiderme.

Fonte: Adaptado de Plikus (2012).

Alguns fatores de transcrição podem ser encontrados na unidade pilosebácea, como é o caso do Oct4 (codificado pelo gene POU5F1), Nanog (codificado pelo gene NANOG homeobox) (YU et al., 2006); e Sox 2 (sex determining region $\mathrm{Y}$ - box2) que é expresso nas células de Merkel da papila dermal e bainha dermal (DRISKELL et al., 2009; LAGA et al., 2010; LESKO et al., 2013). Todos estes fatores estão envolvidos na regulação da pluripotência ou estado de indiferenciação das células (figura 5). 


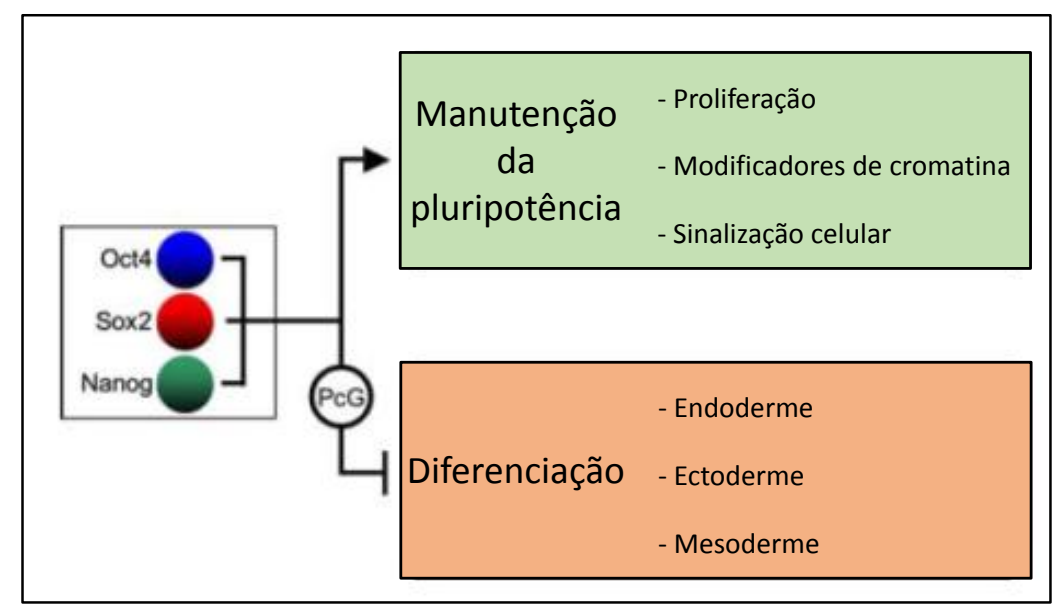

Figura 5 - Manutenção da pluripotência. Oct4/Sox2/Nanog formam o centro da rede transcricional reguladora da maquinaria das células tronco. Centenas de genes alvo são ocupados por estes transcritos impedindo a diferenciação e mantendo a pluripotência das células. PcG (polycomb group) são proteínas que agem como repressores de transcricionais.

Fonte: Modificado de Bosnali (2009).

\subsection{Vibrissas}

As vibrissas, que dentre todos os folículos pilosos são os maiores (figura 6), se desenvolvem na fase fetal também originadas de células da crista neural de forma semelhante a outros apêndices da pele, e de igual forma é constantemente renovada como observado em pelos e cabelos (OSHIMA, et al., 2001). Apresentam morfologia semelhante ao folículo piloso contendo papila dermal, matriz (bulbo) e fio composto por várias camadas. Anatomicamente difere apenas pela presença de um sino vascular envolto por uma cápsula, e esta por fibras musculares estriadas (DORFL, 1982).

Amoh et al., (2009) demonstrou in vivo que células do bulge de pelos são Nestina ${ }^{+}$e Mii et al, (2013) que as do bulge das vibrissas também são positivas para Nestina evidenciando que ambas são células originadas da crista neural. Ambas também são CD34+ que é um marcador utilizado na identificação de células tronco de folículos (AMICI et al., 2009; BOEHNKE et al., 2012). Kobayashi, Rochat e Barrandon (1993), demonstraram in vitro que aproximadamente $95 \%$ das células que compõe o bulge são capazes de formar colônias e Li et al., 2014 mostrou que células da papila dermal de vibrissas expressam e liberam Nestina, p75, Sox9 e Sox10 quando cultivadas, e em coculturas essas proteínas foram capazes de induzir diferenciação em células PC12 (Pheochromocytoma cells). Dessa forma, as vibrissas são um ótimo modelo de estudo, pois são semelhantes aos pelos tanto morfologicamente quanto na expressão de moléculas. Na figura 8 é apresentado um breve 
histórico onde encontram-se alguns dos muitos trabalhos publicados sobre CT extraídas de folículos.

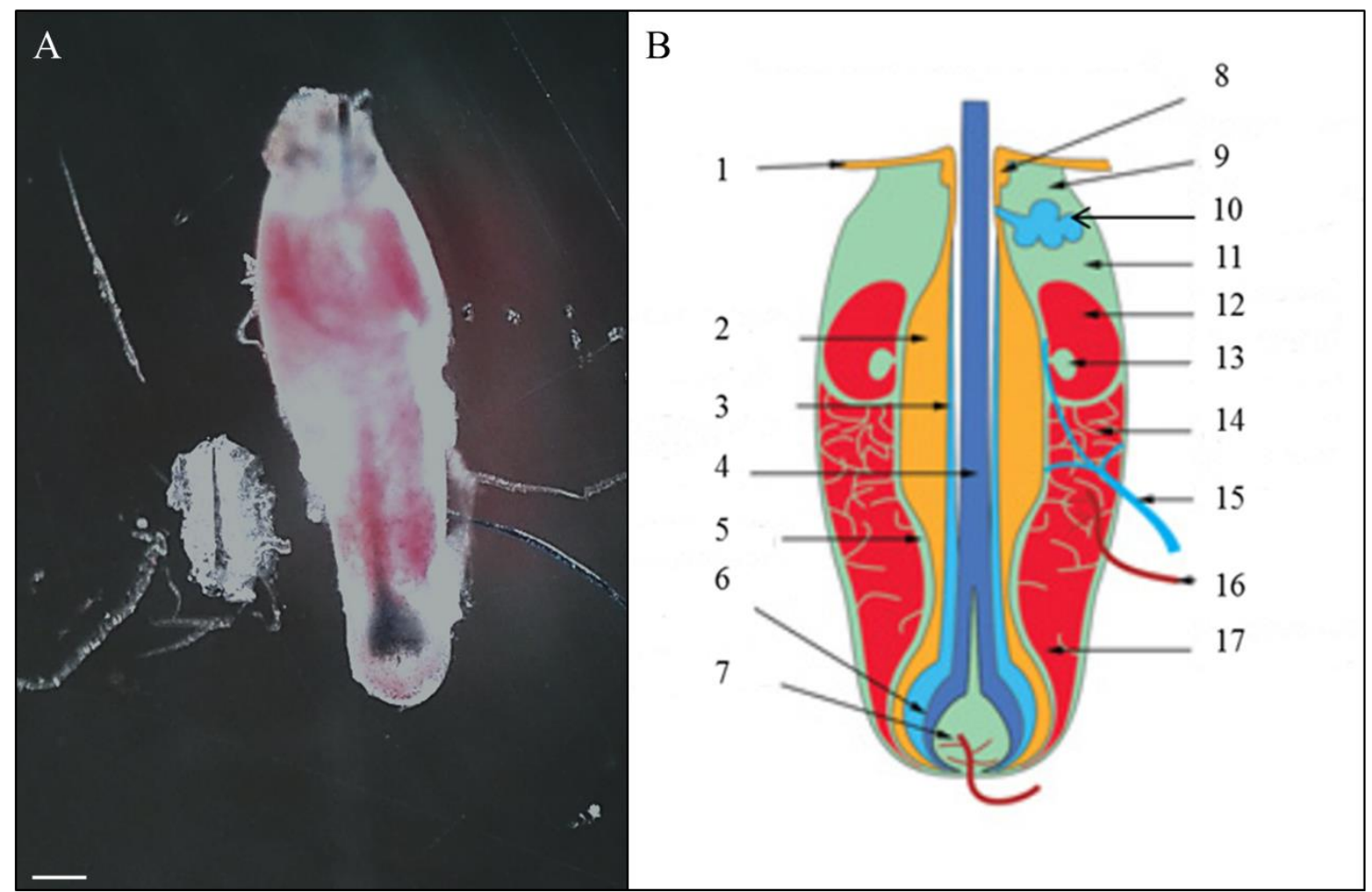

Figura 6 - Vibrissa e sua anatomia. Em (A) pelo (Esquerda) e vibrissa (Direita) de camundongo C57BL-6 vista sob a objetiva da lupa. Escala da barra: $100 \mu \mathrm{m}$. Em (B) figura esquemática de um corte sagital de vibrissa. 1 - Epiderme; 2 - Bainha externa (área do bulge); 3 - Bainha interna; 4 - Fio; 5 - Bainha dermal; 6 - Matriz; 7 - Papila dermal; 8 - Colar; 9 - Corpo cônico externo; 10 - Glândula sebácea; 11 - Corpo cônico interno; 12 - Sinu anelar; 13 - 'Ringwulst'; 14 - Trabecula; 15 - Nervo; 16 - Veia; 17 - Sinu cavernoso. Barra: (A) $500 \mu \mathrm{m}$.

Fonte: Adaptado de PLIKUS (2014).

\subsection{Justificativa}

A identificação de células tronco dos diferentes nichos que compõem o organismo permanece um desafio, pois elas representam menos de $1 \%$ da população de células adultas e sua capacidade de divisão pode ser reduzida uma vez isoladas do organismo (KELLY et al., 2007). Existem várias maneiras de se detectar as células tronco in vivo ou in vitro. As células tronco são caracterizadas por marcadores específicos, tais como antígenos, moléculas e vias de sinalização. Marcadores confiáveis são necessários para caracterizar estas células e marcadores de células tronco precisam ser reavaliados em suas especificidades diferenciais para podermos identificar subconjuntos de células tronco em cada um dos tecidos adultos. 
O folículo piloso e a polpa dentária são provenientes da crista neural, porém a análise da literatura demonstra que diferentes marcadores são utilizados para caracterizar as populações de células tronco isoladas de ambas as fontes. Atualmente pesquisas realizadas com células tronco derivadas de folículos e polpa dentária caminham em direção ao campo da medicina regenerativa, onde estas células são aplicadas no reparo de lesões na medula espinhal, tratamento de lesões na retina ou córnea, cicatrização da pele e até restauração de folículos como tratamento para alopecia (AMOH et al., 2008; GOMES et al., 2010; HEIDARI et al., 2016; KAWASHIMA et al., 2012; MARSHALL et al., 2013; MEAD et al., 2016; BLAZEJEWSKA et al., 2011; NISHINO et al., 2011).

Trabalhos como o de Reynolds e Jahoda, 2004 e Wu et al., 2009 demonstram que células de ambos os nichos podem ser diferenciadas de tal forma que uma pode ser usada para regenerar o tecido da outra. Porém falte-se análise comparativa da expressão diferencial destes marcadores nas células tronco isoladas destas fontes e nos seus respectivos nichos e com isso estes dados poderiam contribuir para uma melhor compreensão da biologia das células tronco assim como da sua possível aplicação terapêutica. 


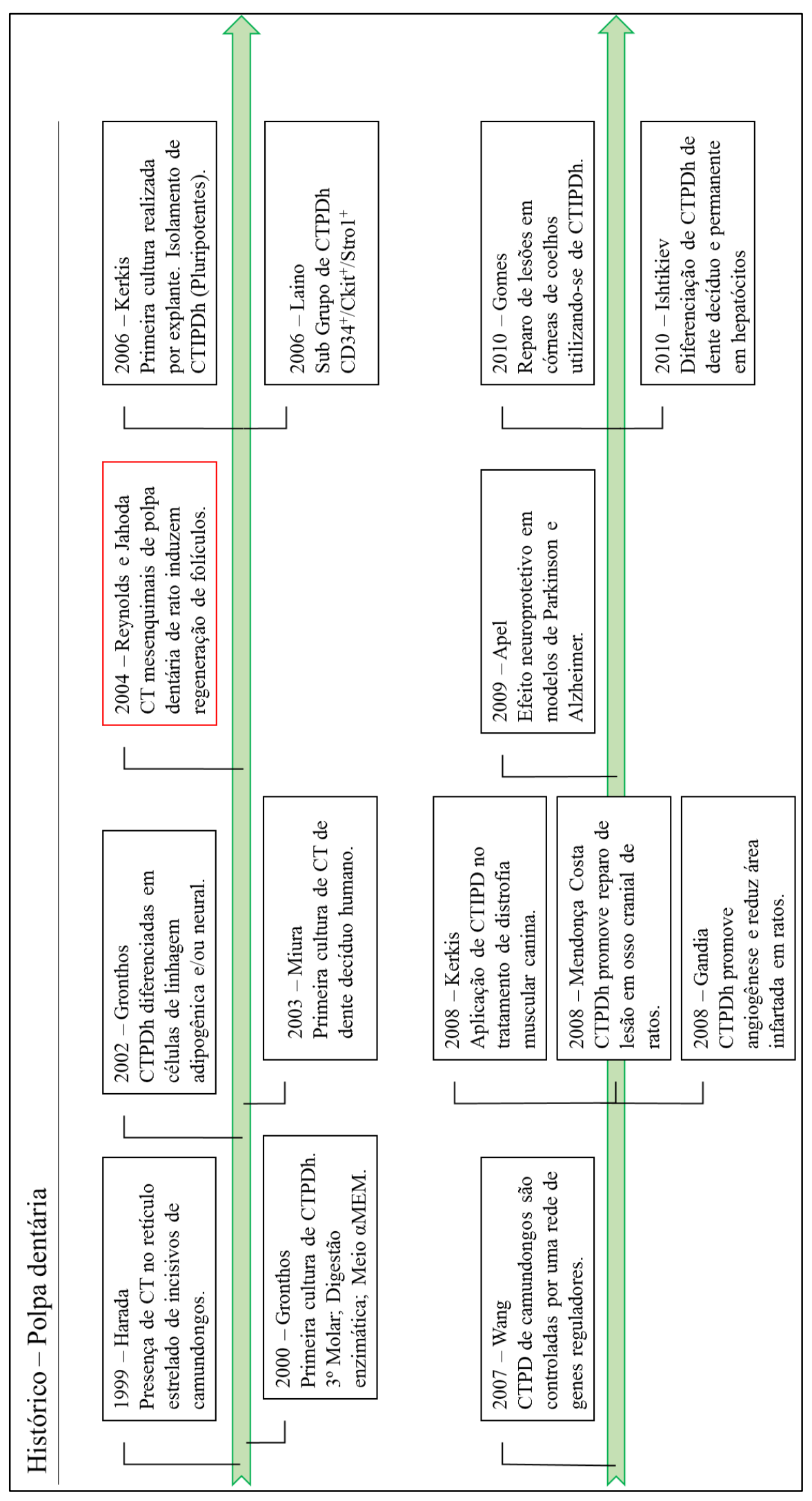

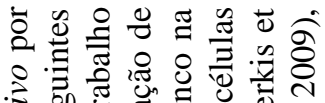

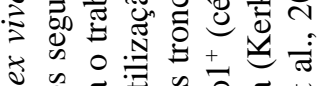

के

急 卷

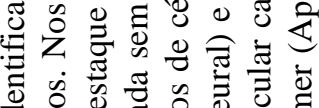

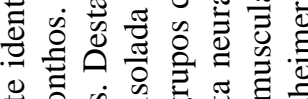

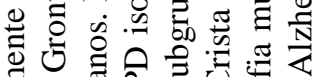

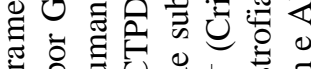

흥

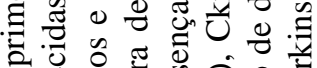

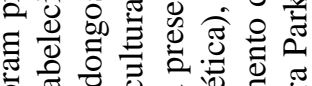

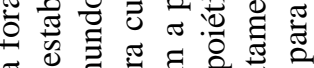

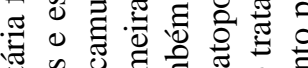

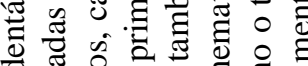

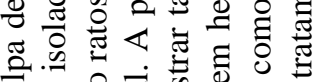

응. 은

๑

送

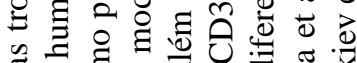
荥

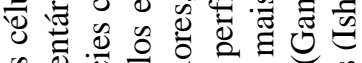
रेष्ठ



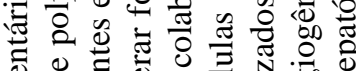

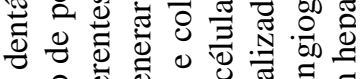
욱 웅현. ช \&



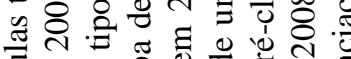



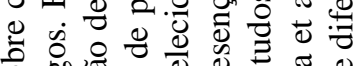

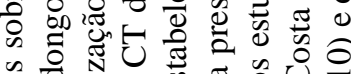
๘

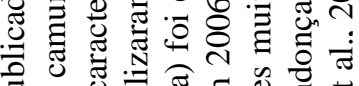

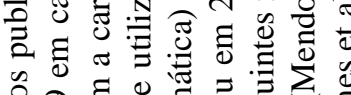

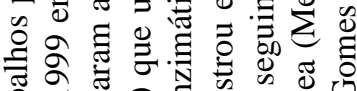



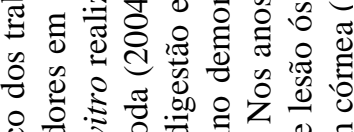





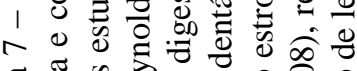

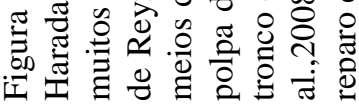




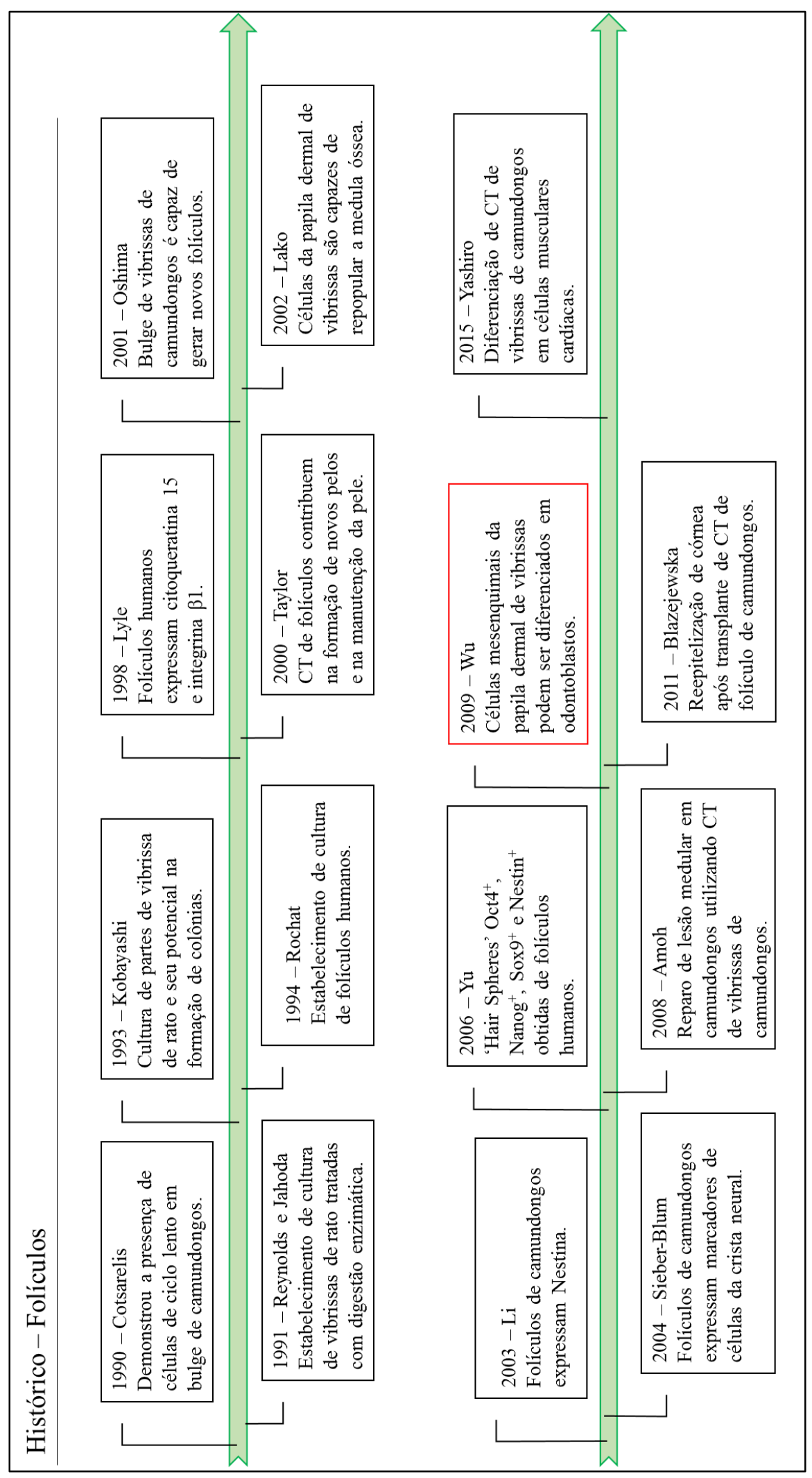



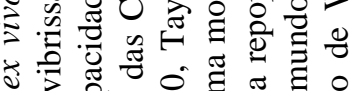

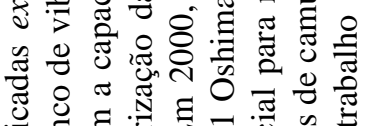

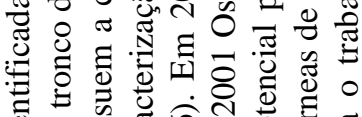

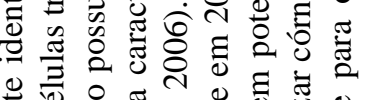

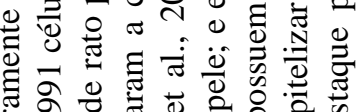

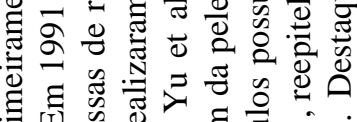



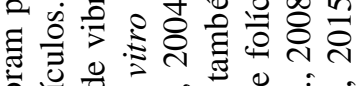
웅



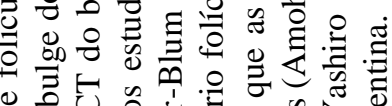
等

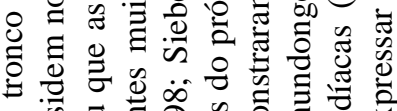



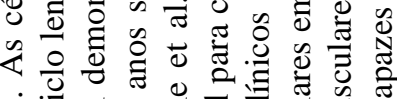

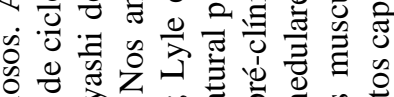

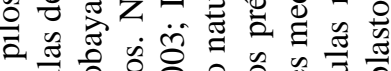

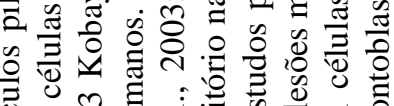

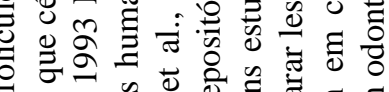



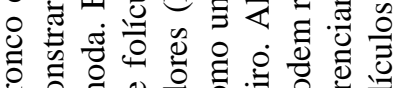

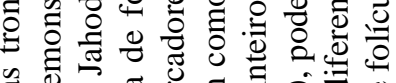
\%

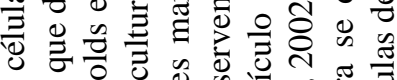

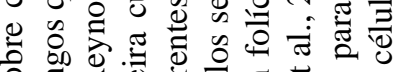

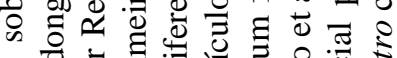

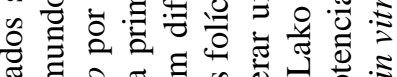



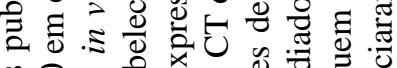

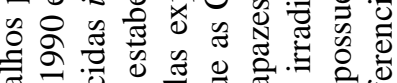

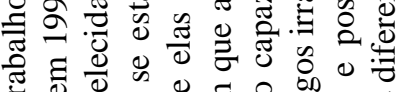

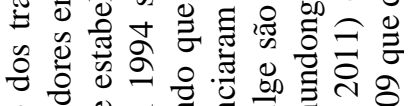

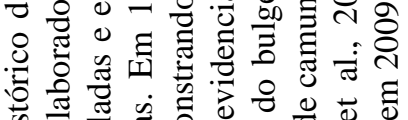

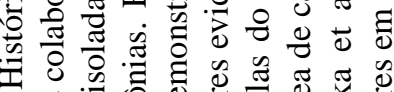
1 ,

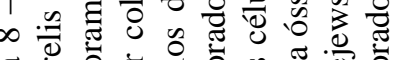
等

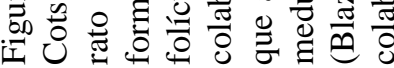


OBJETIVOS 


\section{OBJETIVOS}

\subsection{Objetivo geral}

- Investigar a expressão diferencial dos marcadores de células pluripotentes, mesenquimais e neuroepiteliais nas populações de células tronco isoladas das vibrissas e polpa dentária de camundongos C57BL-6.

\subsection{Objetivos específicos}

- Analisar a expressão dos marcadores CD73, CD90, CD105, Oct4, Nanog, Sox2, CKit, Nestina, Integrina $\alpha 6$, Citoqueratina 15, CD34, LGR5, LGR6, LRig1 e Blimp, em tecido parafinado de polpa dentária e focinho de camundongo C57BL-6 através da técnica de imunohistoquímica.

- Isolar in vivo células tronco de vibrissa e polpa dentária de camundongo C57BL-6;

- Estudar a expressão dos respectivos marcadores através de citometria de fluxo e imunofluorescência em células isoladas de vibrissas e polpa dentária de camundongo C57BL6 cultivadas in vitro.

- Análisar a expressão dos marcadores Oct4, Nanog e Sox2 por PCR utilizando o RNA total das células isoladas e cultivadas in vitro de vibrissas e polpa dentária de camundongo C57BL-6. 
MATERIAL E MÉTODOS 


\section{MATERIAL E MÉTODOS}

Para a realização deste trabalho foram solicitados 15 camundongos C57BL-6, machos, com 30 dias de vida e pesando entre 16 - 20 g. O uso destes animais foi aprovado pela COMISSÃO DE ÉTICA NO USO DE ANIMAIS DO INSTITUTO BUTANTAN (CEUIAB) que emitiu um certificado com o $\mathrm{n}^{\mathrm{o}}$ 1079/13. Os animais foram mantidos em caixas de polipropileno próprias para a criação de roedores. No momento das coletas, os animais foram eutanasiados com a utilização de dose letal dos anestésicos associados Quetamina e Xilazina (100 mg/kg de Quetamina / 5 mg/kg de Xilazina).

\subsection{Fixação e inclusão de material biológico em parafina}

Uma porção do focinho de um camundongo foi fixado em solução de formol $10 \%$ em PBS, com pH corrigido para o pH 7,4. Após fixação por 48 horas o material foi incluído em parafina para dar-lhe estabilidade na hora do corte. O processamento histológico se inicia com a desidratação das amostras com soluções aquosas de álcool (solução menos concentrada $\rightarrow$ solução mais concentrada) até atingir o álcool absoluto. Segue-se então a diafanização do material com banhos sequenciais de xilol e, por fim, o material é imerso em parafina fundida (aproximadamente à $60^{\circ} \mathrm{C}$ ) sendo realizado dois banhos de 1 hora cada (apêndice A).

Ao final do processo o material foi acondicionado em moldes para a confecção dos blocos de parafina. Destes blocos foram feitos cortes histológicos com espessura de $3 \mu \mathrm{m}$, os quais foram colocados em lâminas previamente tratadas com solução de silano $5 \%$ em metanol ([3-Aminopropyl]trimethoxysilane - Sigma Aldrich). Estas lâminas foram utilizadas para a coloração por hematoxilina - eosina e o ensaio de imunohistoquímica.

\subsubsection{Coloração por hematoxilina - eosina}

As lâminas passaram pelo protocolo padrão de coloração por hematoxilina - eosina (apêndice B), onde primeiramente ocorre a remoção da parafina, seguida da hidratação gradual dos cortes utilizando-se soluções aquosas de álcool. Após a hidratação, as lâminas foram coradas por hematoxilina, desidratadas e coradas com eosina. O excesso do corante 
eosina e uma possível água residual foram removidos com banhos sequenciais de álcool absoluto seguindo-se com a diafanização das lâminas utilizando-se banhos sequenciais de xilol e, por fim, montagem das lâminas.

\subsubsection{Ensaio de imunohistoquímica}

As lâminas destinadas para este ensaio passaram por remoção de parafina, desidratação e uma recuperação antigênica com tampão citrato ajustado para o pH 6 foi realizada. Na sequencia a fosfatase endógena foi bloqueada com uma solução $1 \mathrm{mM}$ de levamisol por 10 minutos, duas vezes. Um segundo bloqueio foi realizado com uma solução de albumina bovina a 5\% (BSA - Sigma) em PBS, por 30 minutos. Removeu-se o excesso de albumina e se aplicou os anticorpos primários. Os anticorpos foram diluídos em solução de albumina a $1 \%$ acrescida de $0,01 \%$ de azida sódica. A concentração final dos anticorpos seguiu as instruções do fabricante. A incubação durou entre 16 - 18 horas (overnight). No outro dia, as lâminas foram lavadas e se aplicou os respectivos anticorpos secundários por um período de uma hora. $\mathrm{O}$ excesso de anticorpo secundário foi removido com 3 banhos de PBS e a reação foi revelada utilizando o Sistema de Vermelho Rápido Permanente (Permanent fast red system - Abcam 128992). O excesso do revelador foi removido com banhos sequenciais de água destilada e uma contra-coloração foi realizada com hematoxilina. A seguir, os cortes foram desidratados, diafanizados e as lâminas foram montadas. O protocolo completo encontra-se no apêndice C.

\subsection{Obtenção e estabelecimento de cultura primária da unidade pilosebácea e polpa dentária de camundongos C57BL-6.}

Um camundongo C57BL-6 foi eutanasiado por dose letal dos anestésicos associados Quetamina / Xilazina, numa dosagem três vezes superior ao recomendado para anestesia (recomendação para anestesia, sedação ou analgesia é de $100 \mathrm{mg} / \mathrm{kg}$ de quetamina $/ 5 \mathrm{mg} / \mathrm{kg}$ de xilazina). Depois foram imersos em álcool $70 \%$ por 5 minutos para descontaminação. Com a ajuda de pinças e tesouras removeu-se a pele do focinho do camundongo que foi transferida para uma placa de petri contendo solução tampão de fosfato (PBS) a temperatura ambiente. Com a ajuda de uma lupa (Nikon SMZ 745Z) as unidades pilosebáceas (daqui em diante 
denominadas de vibrissas) foram extraídas do tecido e cuidadosamente limpas removendo-se todo o tecido externo à cápsula (epiderme, derme e hipoderme). Os dentes incisivos dos camundongos foram removidos com o auxilio de tesoura cirúrgica, e todos os tecidos circundantes foram retirados. Vibrissas e dentes foram levados para fluxo laminar, onde passaram por uma segunda descontaminação com três lavagens de PBS acrescido de 5\% de antibiótico penicilina/streptomicina $10.000 \mathrm{U} / \mathrm{mL}$ (Gibco).

Os dentes foram quebrados e com o auxilio de lima tipo K (instrumento odontológico para procedimento endodôntico) a polpa dentária foi removida da cavidade pulpar, e foram cultivadas em placas de $33 \mathrm{~mm}$ (Corning) com meio para cultivo de CTIPD (Kerkis et al., 2006) composto de 87\% de DMEM-F12 (Dulbecco's Modified Eagles Medium - Gibco, Grand Island, NY - USA), 10\% de soro fetal bovino (SFB - Hyclone, Logan, UT - USA), $1 \%$ de penicilina e estraptomicina $10.000 \mathrm{U} / \mathrm{mL}$ (Gibco), 1\% L-Glutamina $200 \mathrm{mM}$ (Gibco) e $1 \%$ de aminoácidos não essenciais (ANE- Gibco). Com a cultura de polpa dentária estabelecida se obteve células para os demais experimentos propostos.

As vibrissas, após descontaminação foram separadas em três grupos.

- Grupo 1: Digestão enzimática das vibrissas com colagenase tipo I (1 mg/mL), em estufa a $37^{\circ} \mathrm{C}$ por 60 minutos.

- Grupo 2: Digestão enzimática das vibrissas com dispase $(1 \mathrm{mg} / \mathrm{mL})$, em estufa a $37^{\circ} \mathrm{C}$ por 60 minutos.

- Grupo 3: Sem digestão enzimática mantidos apenas em PBS em estufa a $37^{\circ} \mathrm{C}$ por 60 minutos.

Após o período de digestão, os três grupos foram lavados duas vezes com PBS e então cultivados, a princípio, com meio para cultivo de CTIPD (Kerkis et al., 2006). A cultura foi feita em placas de $33 \mathrm{~mm}$ (Corning) até atingirem uma semiconfluência $(70-80 \%)$.

\subsection{Determinação do meio para cultivo primário de células isoladas vibrissas e polpa dentária.}

Novas vibrissas foram coletadas de um camundongo da forma descrita no item anterior, onde se optou pela não digestão enzimática, uma vez que se notou diferença na morfologia das células nas culturas. O cultivo destas vibrissas foi feito em diferentes meios de cultura listados na tabela 1. A morfologia das células em expansão foi acompanhada através 
das passagens. As culturas foram mantidas até alcançarem a semiconfluência de $70-80 \%$. Os repiques foram feitos utilizando Tripsina $0,25 \%$ (LGC Biotecnologia) por 4 minutos. As polpas dentárias foram cultivadas seguindo o protocolo estabelecido por Kerkis et al, 2006.

\subsection{Imunofluorescência}

Para este experimento foi utilizado um novo camundongo do qual foi extraído polpa dentária e vibrissa. As células foram obtidas como descrito nos itens 4.1 e 4.2 sendo que não foi utilizada digestão enzimática e o material foi cultivado em meio para CTIPD. Esta combinação foi escolhida devido aos resultados das etapas anteriores. As vibrissas foram cultivadas em placas de 24 poços diretamente sobre as lamínulas, enquanto que as polpas foram cultivadas em garrafas de cultura e ao atingirem a confluência foram tripsinizadas e plaqueadas sobre lamínulas. As células foram lavadas duas vezes por cinco minutos com solução tampão de fosfato (PBS) e depois lavadas uma vez por cinco minutos com uma solução de Tween20 a $0,01 \%$ em PBS. As células correspondentes à marcação imunofluorescente nuclear foram permeabilizadas com Triton 0,01\% (Sigma, St Louis, MO USA) por 10 minutos. Em seguida as células foram lavadas com PBS e depois bloqueadas com albumina bovina a 5\% (BSA - Sigma), e então incubadas com seus respectivos anticorpos primários e armazenadas em geladeira $4{ }^{\circ} \mathrm{C}$ overnight. Os anticorpos utilizados estão listados na tabela 2 (anexos). No dia seguinte, foram lavadas com PBS e então incubadas com seus respectivos anticorpos secundários em temperatura ambiente. As lâminas foram então preparadas em meio de montagem Vectashield com 4',6-Diamidino-2phenylindol (DAPI - Vector Laboratories, Burlingame, CA - USA) e analisadas por microscopia de fluorescência. (Nikon eclipse $\mathrm{N} i$ ). 
Tabela 1 - Meios utilizados para o estabelecimento dos diferentes tipos celulares estudados

\begin{tabular}{|c|c|}
\hline MEIO & COMPOSIÇÃO \\
\hline $\begin{array}{l}\text { 1. Meio para cultivo de } \\
\text { CTIPD }\end{array}$ & $\begin{array}{l}\text { - } 87 \% \text { de DMEM-F12 (Dulbecco’s Modified Eagles } \\
\text { Medium - Gibco, Grand Island, NY - USA); } \\
\text { - } 10 \% \text { de soro fetal bovino (SFB - Hyclone, Logan, } \\
\text { UT - USA); } \\
\text { - } 1 \% \text { de penicilina e estraptomicina } 10.000 \mathrm{U} / \mathrm{mL} \\
\quad \text { (Gibco); } \\
\text { - } 1 \% \text { L-Glutamina } 200 \mathrm{mM} \text { (Gibco); } \\
\text { - } \quad 1 \% \text { de aminoácidos não essenciais (ANE- Gibco). }\end{array}$ \\
\hline 2. Meio Low Glucose & $\begin{array}{l}\text { - } 87 \% \text { de DMEM-Low Glucose (Dulbecco’s Modified } \\
\text { Eagles Medium - Gibco, Grand Island, NY - USA); } \\
\text { - } 10 \% \text { de soro fetal bovino (SFB - Hyclone, Logan, } \\
\text { UT - USA); } \\
\text { - } 1 \% \text { de penicilina e estreptomicina } 10.000 \mathrm{U} / \mathrm{mL} \\
\quad \text { (Gibco); } \\
\text { - } 1 \% \text { L-Glutamina } 200 \mathrm{mM} \text { (Gibco); } \\
\text { - } \quad 1 \% \text { de aminoácidos não essenciais (ANE- Gibco). }\end{array}$ \\
\hline 3. Meio Neurobasal & $\begin{array}{l}\text { - } 98 \% \text { de meio neurobasal [-] L-Gluatamina (Gibco - } \\
\text { Grand Island, NY - USA); } \\
\text { - } \quad 2 \% \text { B27 (Gibco - Grand Island, NY - USA) }\end{array}$ \\
\hline 4. Meio iPS & $\begin{array}{l}\text { - Meio mTeSR }{ }^{\mathrm{TM}} \text { basal medium for maintenance of } \\
\text { hESCs and hiPSCs (Stemcell technologies Cat } n^{\circ} \\
\text { 05850) }\end{array}$ \\
\hline
\end{tabular}




\subsection{PCR}

\subsubsection{Extração de RNA total}

Para este ensaio se utilizou os marcadores Oct4, Sox2, Nanog e GAPDH. As células da vibrissa e polpa dentária foram cultivadas em garrafas de cultura de $75 \mathrm{~cm}^{2}$ (Corning, NY - USA) até atingirem 70 - 80\% de confluência, e neste ponto elas foram digeridas por método enzimático. O RNA total foi extraído a partir dos lisados celulares de acordo com as instruções do fabricante para o RNeasy Mini Kit (Qiagen, Valencia, CA). As amostras de RNA foram quantificadas com um Nano-Drop, ND-1000 espectrofotômetro (Thermo Scientific, Waltham, MA), onde o material entre a razão de 260/280 e próximos de 2 foram selecionados para posterior análise. A eletroferese com gel de agarose foi usada para confirmar a integridade do RNA total extraído.

\subsubsection{Síntese do cDNA}

A obtenção do cDNA seguiu as instruções do kit ImProm-II ${ }^{\mathrm{TM}}$ Reverse Transcriptase System que funciona em duas etapas. A primeira consiste em uma incubação do RNA total com os oligoDT (Primers) em um ciclo a $70{ }^{\circ} \mathrm{C}$ por cinco minutos seguido por um ciclo a 4 ${ }^{\circ} \mathrm{C}$ por cinco minutos formando assim o mix1. A segunda etapa consiste da preparação do mix 2 para a transcrição reversa composto de $5 \mu \mathrm{L}$ de água DEPC, $4 \mu \mathrm{L}$ reaction buffer $5 \mathrm{x}, 3$ $\mu \mathrm{L} \mathrm{MgCl}_{2}, 1 \mu \mathrm{L}$ de dNTP, $1 \mu \mathrm{L}$ de RNAsin, $1 \mu \mathrm{L}$ de transcriptase reversa (enzima) o qual é adicionada o ainda o mix1. O mix total foi submetido a uma ciclagem de 5 minutos a $25{ }^{\circ} \mathrm{C}$; 1hora a $42{ }^{\circ} \mathrm{C} ; 15$ minutos a $70{ }^{\circ} \mathrm{C}$. E o cDNA produzido na reação foi armazenado a $4{ }^{\circ} \mathrm{C}$.

\subsubsection{PCR}

Após a síntese do cDNA foi realizada a reação de PCR utilizando os primers descritos na tabela 2 no anexo. A reação foi feita de acordo com do protocolo do kit Go Taq $^{\circledR}$ Green Master Mix. O tubo foi transferido para um termociclador (Mastercycler gradiente - 
Eppendorf) e submetido a seguinte ciclagem térmica: 1 ciclo de $95{ }^{\circ} \mathrm{C}$ por 5 minutos, 30 ciclos de $\left[95{ }^{\circ} \mathrm{C} 1\right.$ minuto, $62{ }^{\circ} \mathrm{C}$ por 1 minuto, $72{ }^{\circ} \mathrm{C}$ por 1 minuto], 1 ciclo $72{ }^{\circ} \mathrm{C}$ por 1 minuto. As amostras foram armazenadas em freezer $-20^{\circ} \mathrm{C}$. Os produtos amplificados foram analisados através de eletroforese em gel de agarose $1,2 \%$, corados por brometo de etídio (Invitrogen) e visualizados e fotodocumentados em um transiluminador de luz ultravioleta (Biometra BioDocAnalyze - Uniscience).

\subsection{Citometria de fluxo}

Foram feitas culturas de polpa dentária $(3 n)$ e de vibrissas $(3 n)$ para a obtenção de células que foram submetidas à citometria de fluxo. $\mathrm{O}$ experimento foi realizado com células até a quarta passagem, a fim de se obter uma população suficientemente indiferenciada. A análise foi executada no citômetro BD Accuri C6 com dois lasers (azul e vermelho) (488 nm e $633 \mathrm{~nm}$ respectivamente). As células foram tripsinizadas, centrifugadas à $300 \mathrm{G}$ por 5 minutos e ressuspendidas em PBS em uma concentração de 1 x $10^{5}$ células/mL por tubo cônico.

Para cada anticorpo foi utilizado um tubo. Nas marcações nucleares as células passaram por uma permeabilização com solução $0,1 \%$ de Triton X-100 em PBS, por 10 minutos e depois todos os tubos passaram por uma etapa de bloqueio onde receberam uma solução de BSA 5\%. Após o bloqueio, os anticorpos primários foram aplicados seguindo a diluição do fabricante (diluição feita em BSA 1\%) e as células ficaram armazenadas em refrigerador $4{ }^{\circ} \mathrm{C}$ overnight. No dia seguinte, as amostras foram lavadas com PBS e centrifugadas. Cada tubo recebeu seu respectivo anticorpo secundário, onde após uma hora as células foram lavadas com PBS e ressuspendidas em $300 \mu \mathrm{L}$ de tampão.

O citômetro foi calibrado utilizando esferas de calibração (Spherotech 8-Peak Validation Beads - PN 653144) e (Spherotech 6-Peak Validation Beads - PN 653145) fornecidas pelo fabricante e para cada amostra foram contados no mínimo 10.000 eventos. Observaram-se os seguintes marcadores nas células tanto de vibrissas quanto de polpa dentária: CD44, CD45, CD73, CD90, CD105, Oct 4, Nanog, Sox 2, cKit, Nestin, Integrina a6, Citoqueratina 15, CD34, Lgr5, Lgr6, Lrig1, Blimp 1. Os dados obtidos foram analisados no software GraphPadPrism 5.0 e foi realizado teste t de Student seguido e o teste MannWhitney. 
RESULTADOS 


\section{RESULTADOS}

\subsection{Caracterização ex vivo de marcadores imunofenotípicos para células tronco na vibrissa e polpa dentária utilizando o método de imunohistoquímica}

O nicho de células tronco refere-se a um microambiente dentro de um sítio anatômico específico onde as células tronco podem ser encontradas. Para se demonstrar esse nicho de forma geral cortes histológicos de vibrissas e dentes foram corados por hematoxilina - eosina (HE) e por Masson (figura 9 - 12).
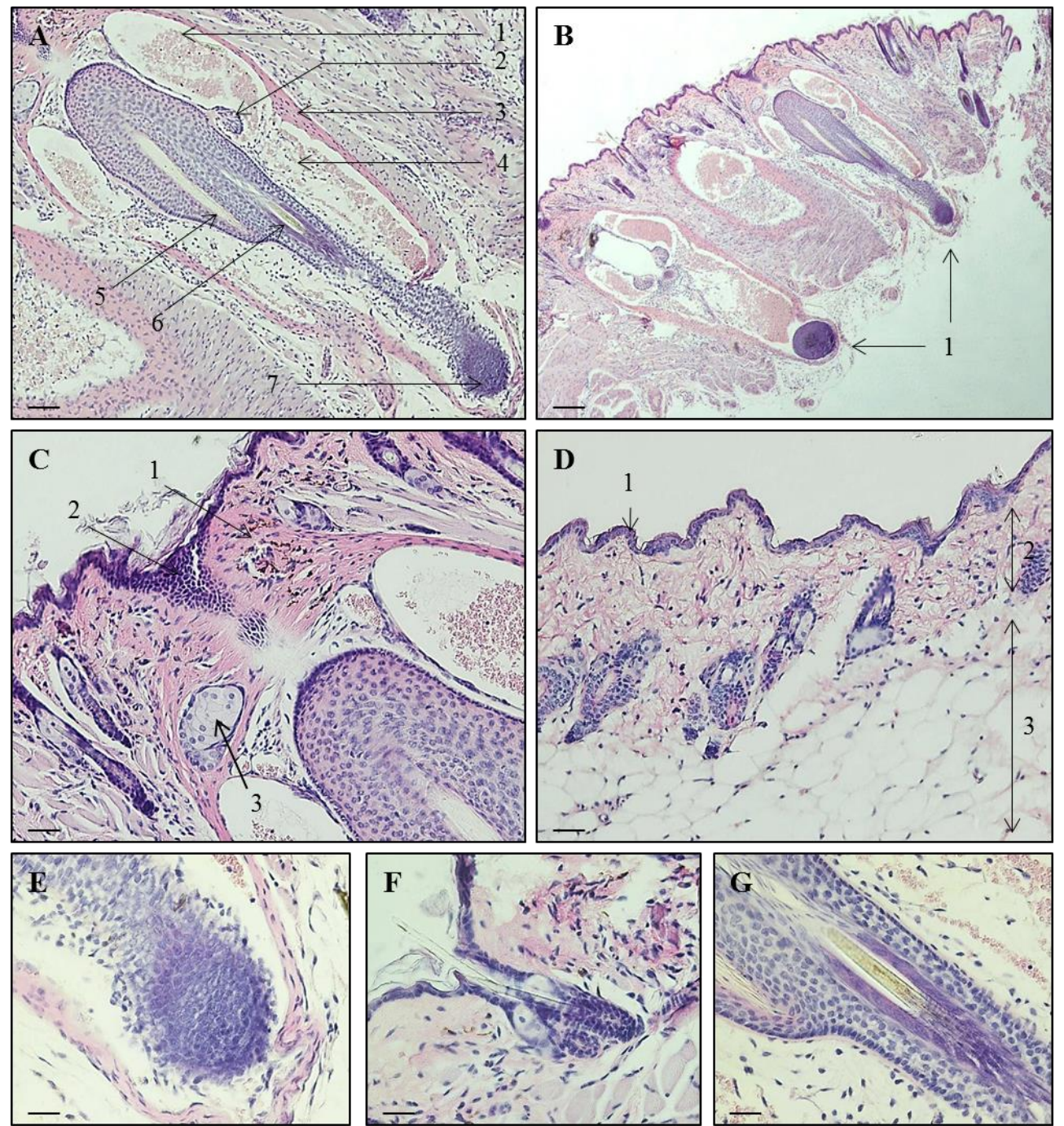

Figura 9 - Cortes histológicos de epiderme de focinho de camundongo corados por HE. Em (A) corte sagital de vibrissa, 200 x. 1 - Sinu anelar. 2 - 'Ringwulst'. 3 - Cápsula. 4 - Trabécula. 5 - Vibrissa (fase telógena). 6 - Vibrissa (fase anágena). 7 - Papila dermal. Em (B) epiderme do focinho. 100 x. 1 Vibrissas. Em (C) detalhe da epiderme e infundíbulo (porção da vibrissa mais próxima da epiderme), 400 x. 1 - Corpo Cônico. 2 - Colar. 3 - Glândula sebácea. Em (D) corte de pele, 400 x. 1 - Epiderme. 2 - Derme. 3 - Hipoderme. Em (E) bulbo da vibrissa, 400 x. Em (F) pelo, 400 x. Em (G) detalhe da raiz da vibrissa, $400 \mathrm{x}$. Barras: (A) $100 \mu \mathrm{m}$, (B) $200 \mu \mathrm{m}$, (C - G) $50 \mu \mathrm{m}$. 


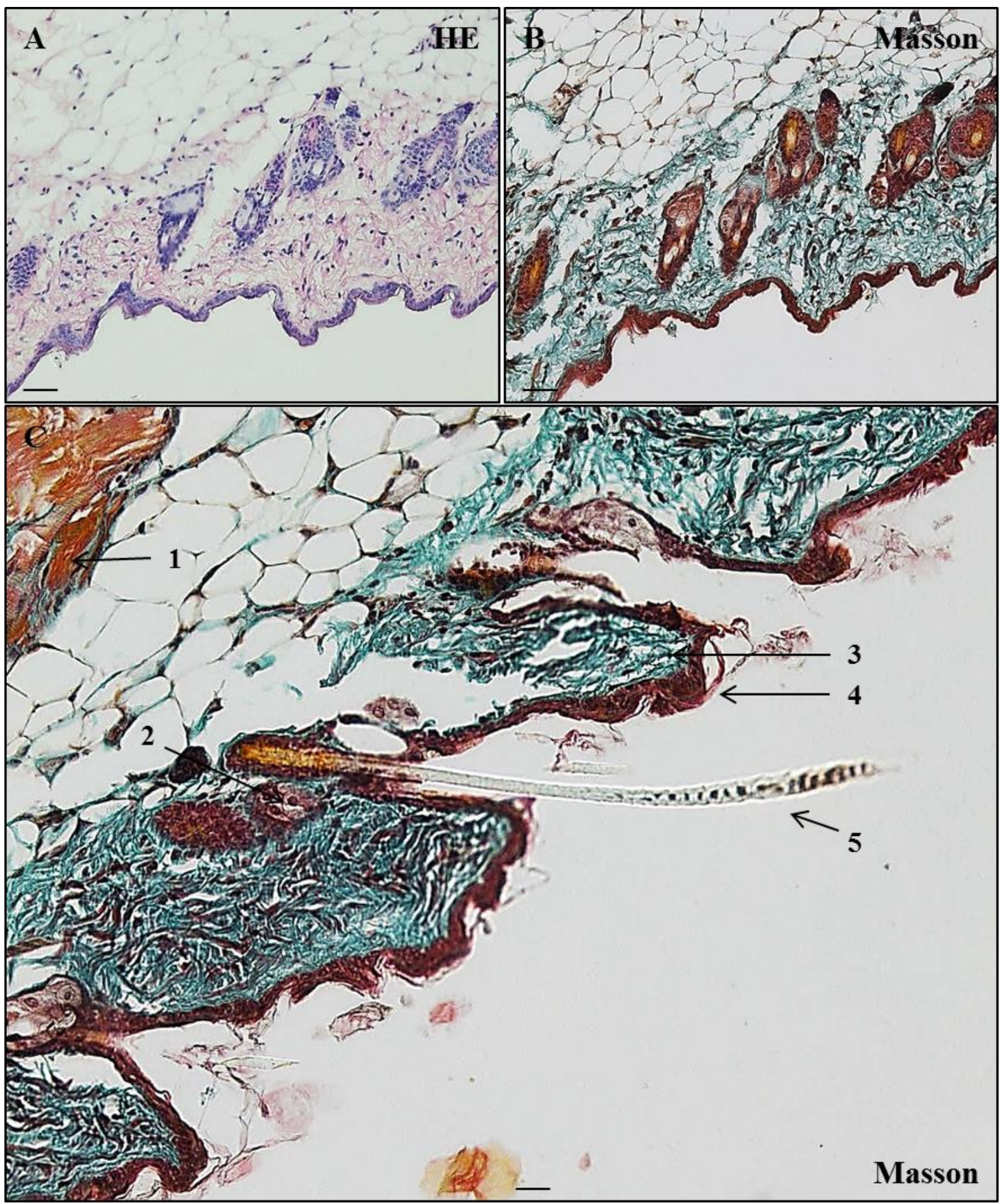

Figura 10 - Cortes histológicos de epiderme de focinho de camundongo corados por HE e Masson. Em (A) coloração por $\mathrm{HE}$ com pelos na região da epiderme, 400 x. Em (B) mesmo corte histológico apresentado em A, mas corado por Tricrômio de Masson. Fibras colágenas em verde e folículos em marrom, 400 x. Em (C) detalhe da epiderme corada por Masson, 400 x. 1 - Músculo estriado esquelético corado em tom de ferrugem. 2 - Glândula sebácea. 3 - Fibras colágenas coradas em verde. 4 - Epiderme corada em marrom. 5 - Pelo. 

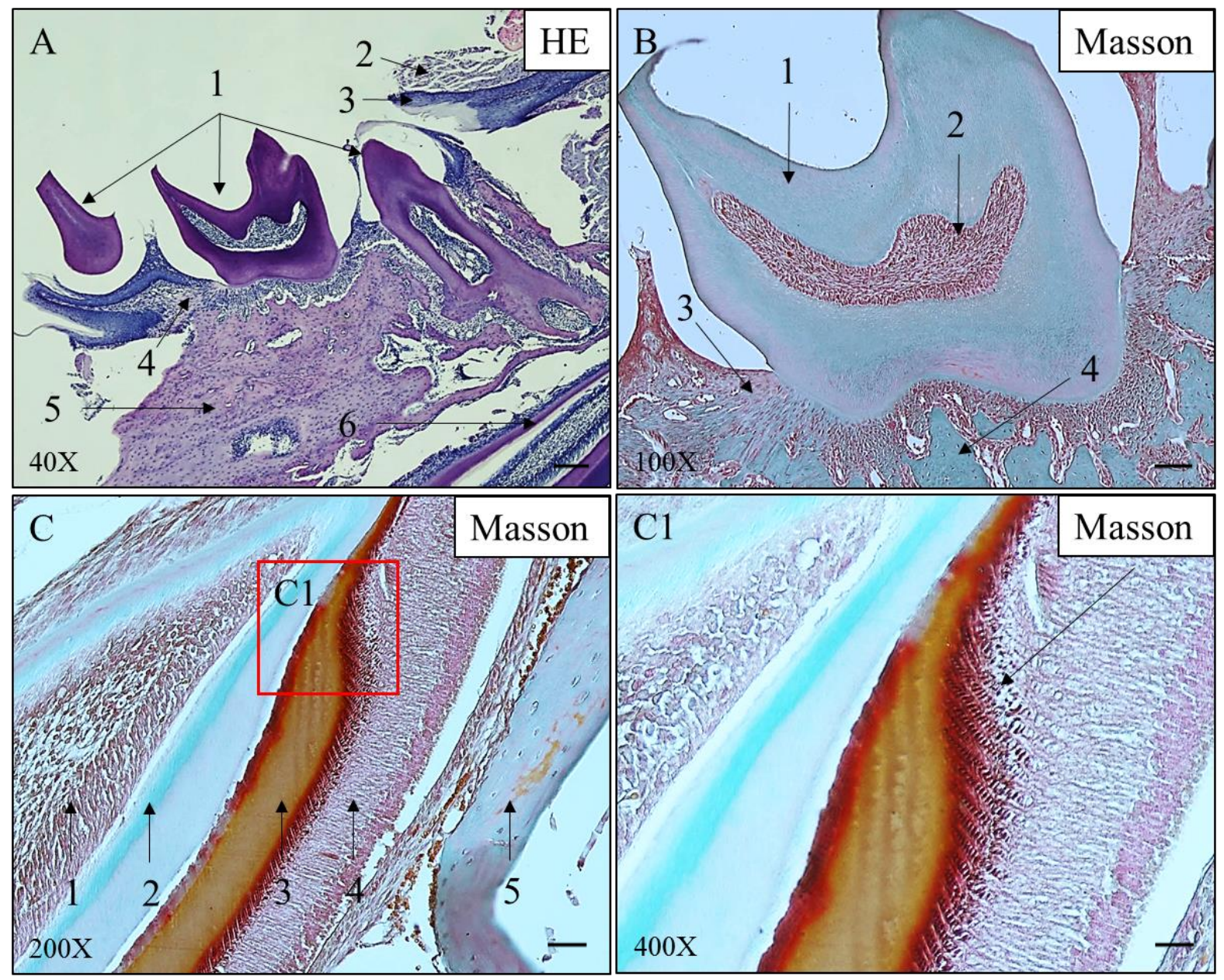

Figura 11 - Cortes histológicos da mandíbula de camundongo corados por HE e Masson. Em (A) corte sagital da mandíbula. 1 - Dentes molares. 2 - Músculo. 3 - Epetélio gengival. 4 - Ligamento periodontal. 5 Osso (mandíbula). 6 - Dente incisivo. Em (B) dente corado por tricrômio de Masson. 1 - Dentina. 2 - Polpa dentária. 3 - Ligamento periodontal. 4 - Osso (mandíbula). Em (C) dente incisivo corado por tricrômio de Masson. 1 - Polpa dentária. 2 - Dentina. 3 - Esmalte. 4 - Ameloblastos. 5 - Osso (mandíbula). Em (C1) a seta evidencia a deposição de esmalte pelos ameloblastos. Barras: (A) 400 $\mu \mathrm{m}$, (B) $200 \mu \mathrm{m}$, (C) $100 \mu \mathrm{m}$, (D) $50 \mu \mathrm{m}$. 

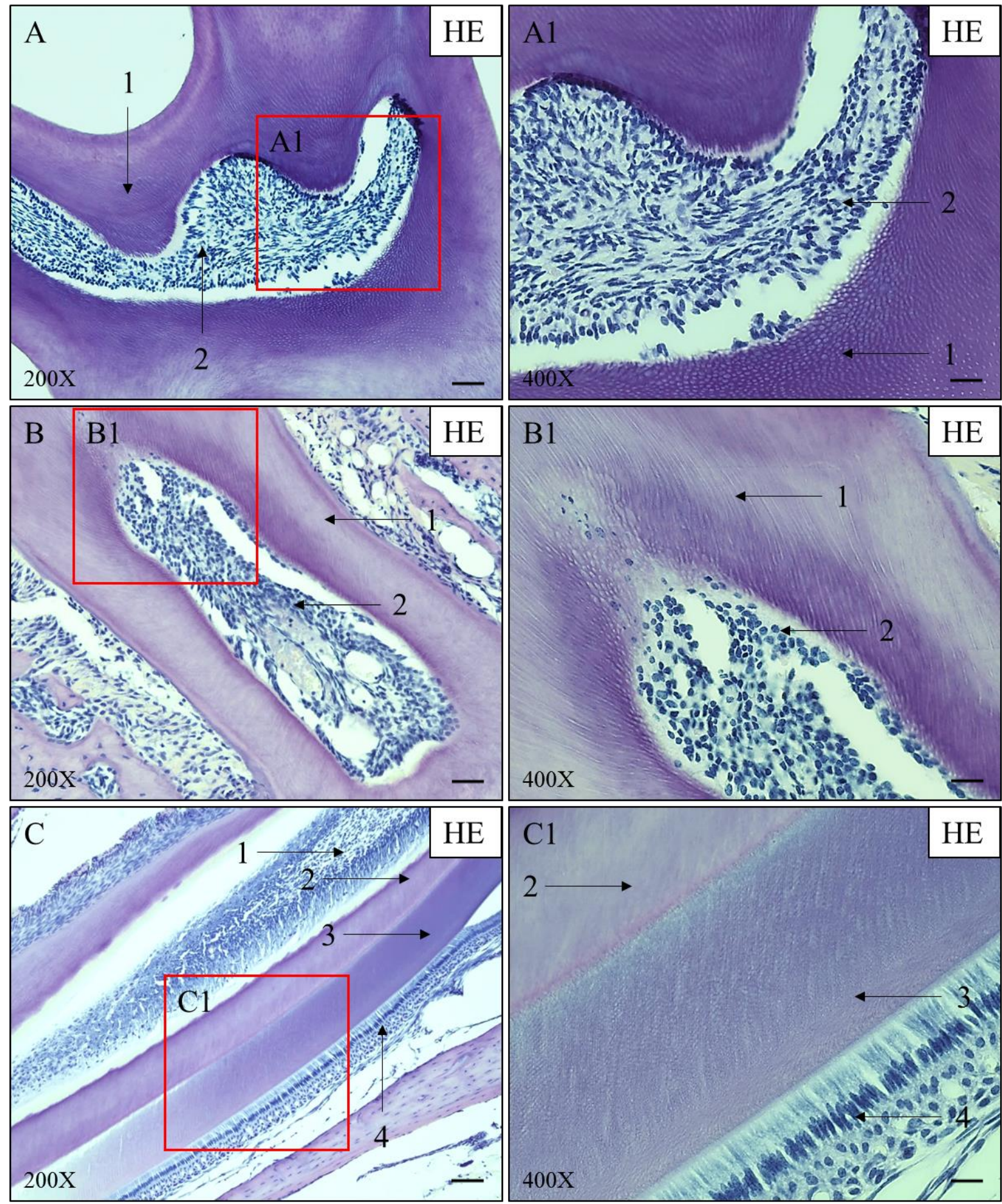

Figura 12 - Cortes histológicos da mandíbula de camundongo corados por HE. Em (A) e (B) dente molar. 1 Dentina. 2 - Polpa dentária. Em (A1) e (B1) temos uma ampliação de (A) e (B). Em (C) corte sagital de incisivo. 1 - Polpa dentária. 2 - Dentina. 3 - Esmalte. 4 - Ameloblastos. Em (C1) corte sagital de incisivo ampliado. Barras: (A, B e C) $100 \mu \mathrm{m},(\mathbf{A 1}, \mathbf{B} 1$ e C1) $50 \mu \mathrm{m}$. 
Utilizamos a técnica de imunohistoquímica para caracterizar ex vivo os marcadores imunofenotípicos para células tronco de vibrissa e polpa dentária. No ensaio de imunohistoquímica foi possível identificar uma população celular imunopositiva para Ckit onde, na vibirissa, a imunomarcação para CKit ocorreu no citoplasma das células da bainha externa das vibrissas, e na cutícula da vibrissa (figura 13). Polpa dentária mostrou-se negativa (figura 13)

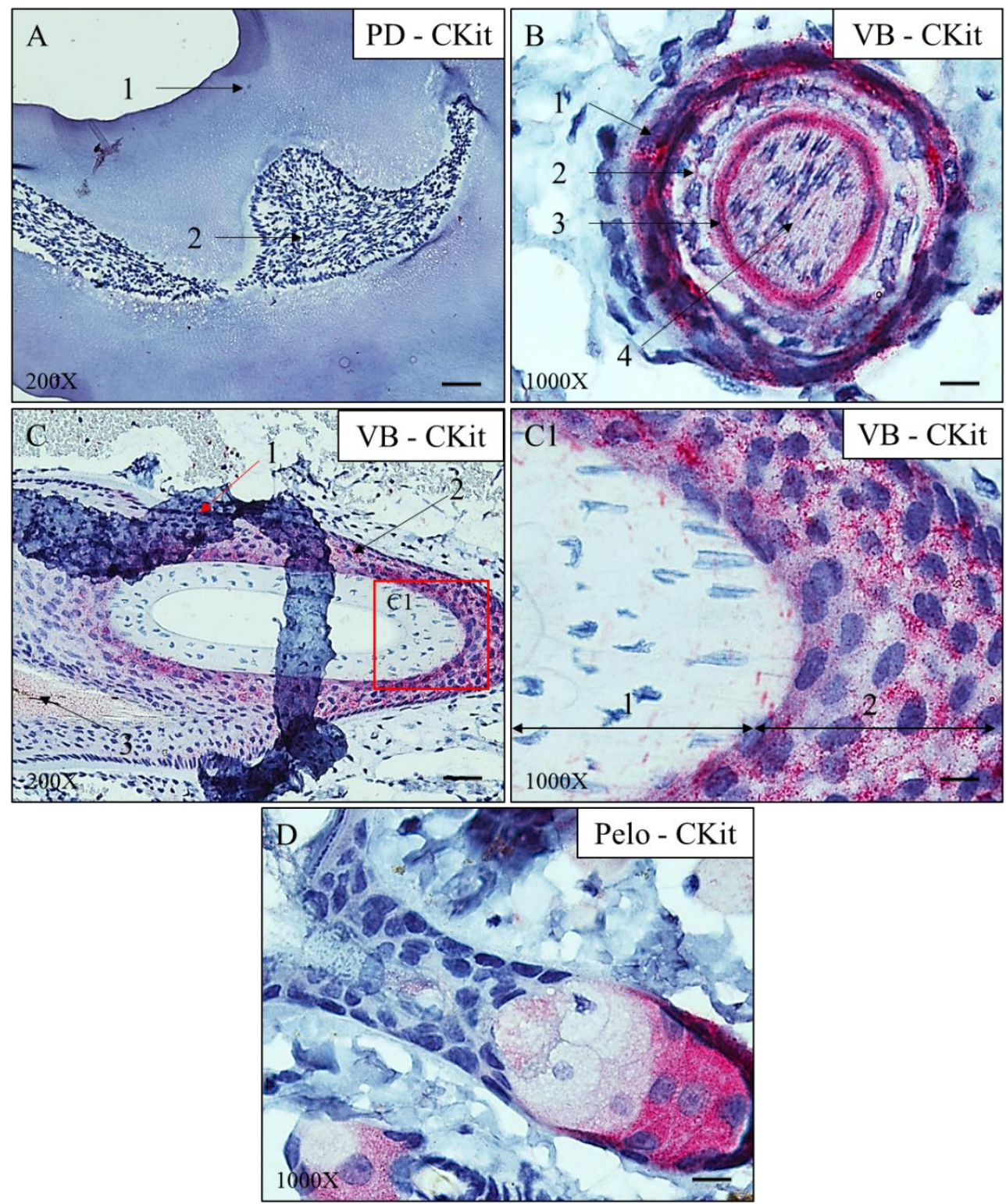

Figura 13 - Imunohistoquímica para Ckit em cortes histológicos de mandíbula e epiderme de focinho de camundongo C57BL6. Em (A) corte sagital de dente que se demonstrou negativo para CKit. 1 Dentina. 2 - Polpa dentária. Em (B) corte transversal de vibrissa onde é possível se observar positividade para Ckit na bainha externa e cutícula. 1 - Bainha externa. 2 - Bainha interna. 3 Cutícula. 4 - Córtex. Em (C) corte sagital de vibrissa. 1 - Cápsula. 2 - Bainha externa. 3 - Raiz da Vibrissa. Notar positividade na bainha externa. Em (C1) temos uma ampliação da área positiva para Ckit onde é possível se ver a especificidade da marcação, onde a bainha interna (1) é negativa e bainha externa (2) é positiva. Em (D) temos um pelo marcado positivamente para Ckit. PD Polpa dentária. VB - Vibrissa. Barras: (A) $100 \mu \mathrm{m}$, (B) $20 \mu \mathrm{m}$, (C) $100 \mu \mathrm{m}$, (C1) $20 \mu \mathrm{m}$, (D) 20 $\mu \mathrm{m}$. 
No ensaio de imunohistoquímica foi possível identificar uma população celular imunopositiva para Ckit onde, na vibirissa, a imunomarcação para CKit ocorreu no citoplasma das células da bainha interna e no cortex (figura 14). Polpa dentária mostrou-se também positiva em odontoblastos (figura 14).


Figura 14 - Imunohistoquímica para Nestina em cortes histológicos de mandíbula e epiderme de focinho de camundongo C57BL6. Em (A) corte sagital de dente que mostrou positividade para Nestina em odontoblastos (seta vermelha). 1 - Dentina. 2 - Polpa dentária. Em (B) corte sagital de dente positivo para Ckit (seta vermelha). Em (C) corte sagital de vibrissa. 1 - Bainha externa. 2 - Bainha interna positiva para Nestina. 3 - Raiz da Vibrissa também positiva para Nestina. Em (D) corte transversal de vibrissa. 1 - Bainha externa. 2 - Bainha interna positiva para Nestina. 3 - Cutícula. 4 - Córtex positivo para Nestina. PD - Polpa dentária. VB - Vibrissa. Barras: (A) $50 \mu$ m, (B) 20 $\mu \mathrm{m}$, (C) $100 \mu \mathrm{m}$, (D) $20 \mu \mathrm{m}$. 
Na vibrissa ex vivo, também foi investigado a presença de células imunopositivas para os marcadores de pluripotencia Oct4, Nanog e Sox. Interessantemente não foram identificadas células imunopositivas para estes três anticorpos em ambos tecidos (figura 15).

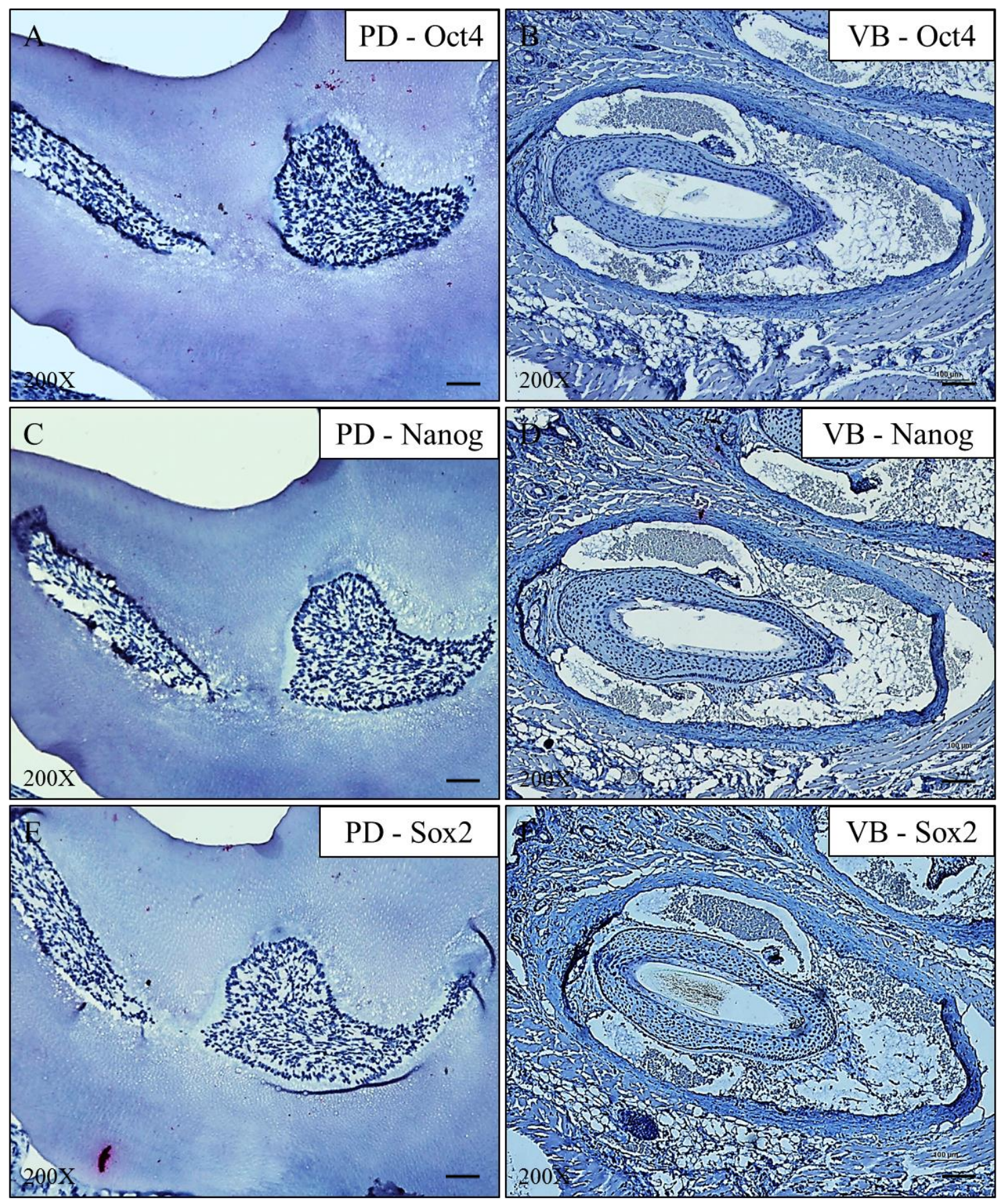

Figura 15 - Imunohistoquímica para Oct4, Nanog e Sox2 em cortes histológicos de mandíbula e epiderme de focinho de camundongo C57BL6. (A, C e E) Cortes sagitais de dente que não apresentaram positividade para nenhum dos marcadores. (B, D e F) Cortes sagitais de vibrissa negativas para os marcadores Oct4, Nanog e Sox2. PD - Polpa dentária. VB - Vibrissa. Barras: (A - F) $100 \mu \mathrm{m}$. 
Polpa dentária e vibrissas foram testadas quanto a presença dos marcadores CD73 (figura 16), CD90 (figura 17) e CD105 (figura 18) que são marcadores de células tronco mesenquimais. Células imunopositivas para os anticorpos CD73 e CD105 foram observadas na bainha externa das vibrissas (figura 16 e 18). Na polpa dentária não foi observada marcação para nenhum dos 3 marcadores.



Figura 16 - Imunohistoquímica para CD73 em cortes histológicos de mandíbula e epiderme de focinho de camundongo C57BL6. Em (A) polpa dentária negativa para CD73. 1 - Dentina. 2 - Polpa dentária. Em (B) corte transversal de vibrissas (1) mostrando positividade para CD73 em sua bainha externa. Setas vermelhas evidenciam pelos da epiderme também positivos para CD73. Em (C) corte sagital de vibrissa. Em (C1) temos a primeira ampliação da imagem (C) onde é possível se observar a especificidade da marcação para CD73 (1 - bainha externa positiva. 2 bainha interna negativa). Em (C2) temos a segunda ampliação da imagem (C) onde é possível se observar um pequeno grupo de células positivas para CD73 na bainha interna, sugerindo talvez uma transição entre as camadas. PD - Polpa dentária. VB - Vibrissa. Barras: (A) $50 \mu \mathrm{m}$, (B) 100 $\mu \mathrm{m}$, (C) $100 \mu \mathrm{m}$, (C1) $20 \mu \mathrm{m}$, (C2) $20 \mu \mathrm{m}$. 

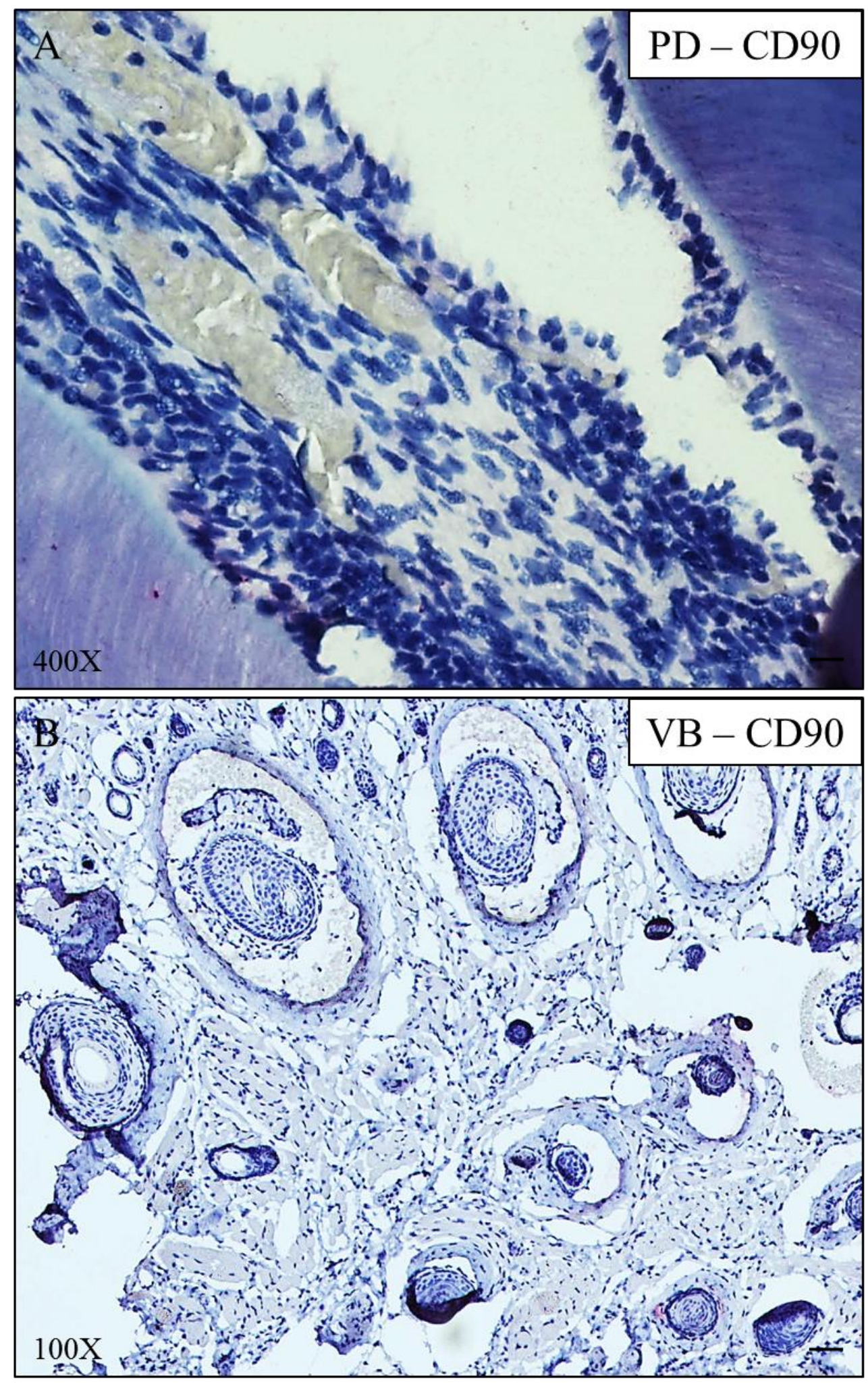

Figura 17 - Imunohistoquímica para CD90 em cortes histológicos de mandíbula e epiderme de focinho de camundongo C57BL6. Em (A) corte sagital de dente. Em (B) corte transversal de vibrissas. Ambos tecidos foram negativos para a marcação de CD90. PD - Polpa dentária. VB - Vibrissa. Barras: (A) $50 \mu \mathrm{m}$, (B) $200 \mu \mathrm{m}$. 

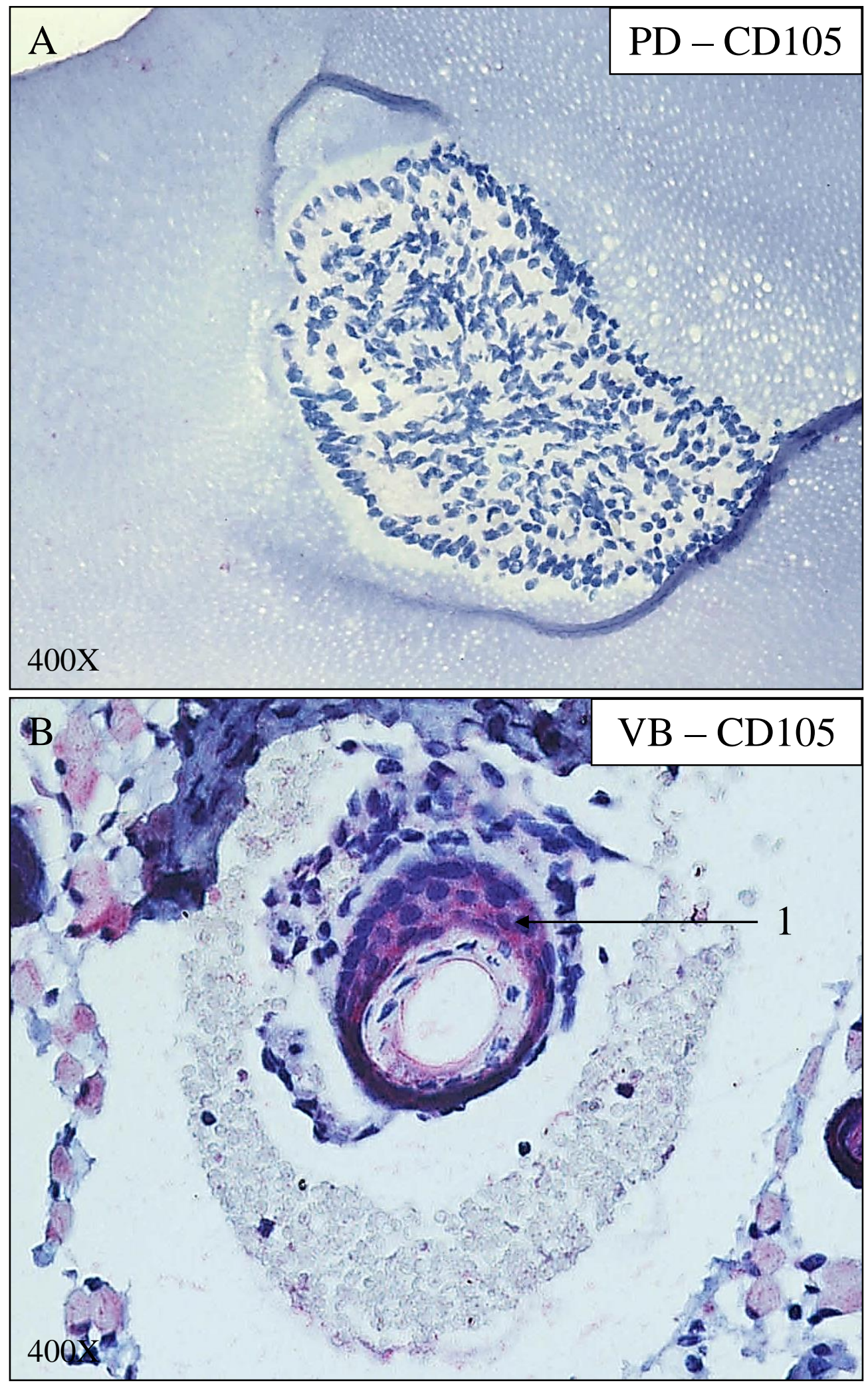

Figura 18 - Imunohistoquímica para CD105 em cortes histológicos de mandíbula e epiderme de focinho de camundongo C57BL6. Em (A) corte sagital de dente que se mostrou negativo para o marcador CD105. Em (B) corte transversal de vibrissa no qual é possível se observar positividade para CD105 na bainha externa da vibrissa. PD - Polpa dentária. VB - Vibrissa. Barras: (A e B) 50 $\mu \mathrm{m}$. 
A presença de Integrina $\alpha 6$ e Citoqueratina 15 também foi estudada. Na polpa dentária algumas células apresentaram uma leve marcação para Integrina $\alpha 6$ (figura 19 A e B) enquanto que vibrissas apresentaram marcação na bainha externa (figura 19D). Citoqueratina 15 não esteve presenta na polpa dentária, porém estava intensamente expressa no citoplasma de um grupo de células basais dentro da bainha externa das vibrissas (figura 20). Alguns pelos também se mostraram positivos para Citoqueratina 15 (figura 20B).
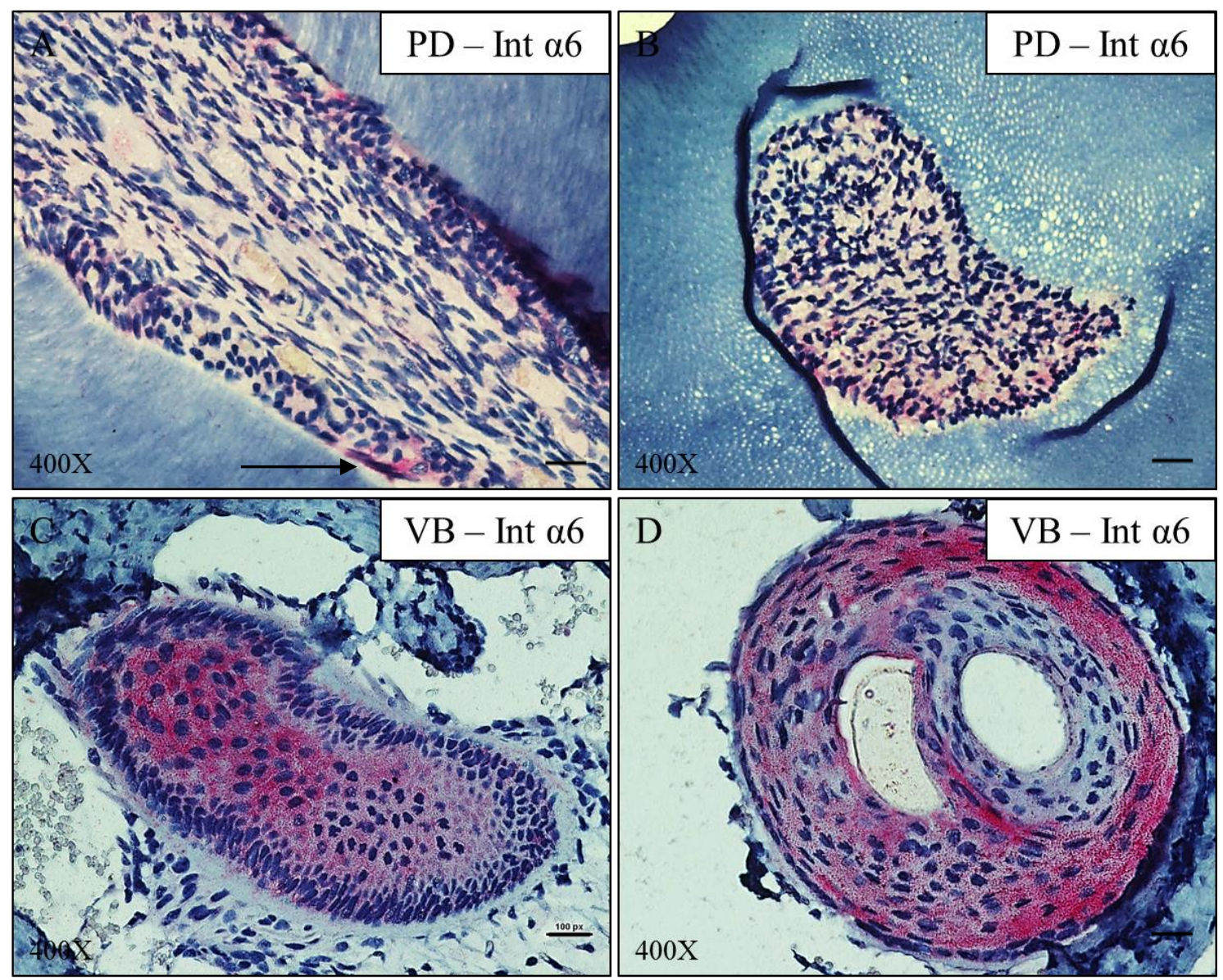

Figura 19 - Imunohistoquímica para Integrina $\alpha 6$ em cortes histológicos de mandíbula e epiderme de focinho de camundongo C57BL6. Em (A) e (B) corte sagital de dente que se mostrou fracamente positivo para o marcador Integrina $\alpha 6$. Em (C) corte sagital de vibrissa. Em (D) corte transversal de vibrissa no qual é possível se observar positividade para Integrina $\alpha 6$ na bainha externa da vibrissa. PD - Polpa dentária. VB - Vibrissa. (A - D) $50 \mu \mathrm{m}$. 

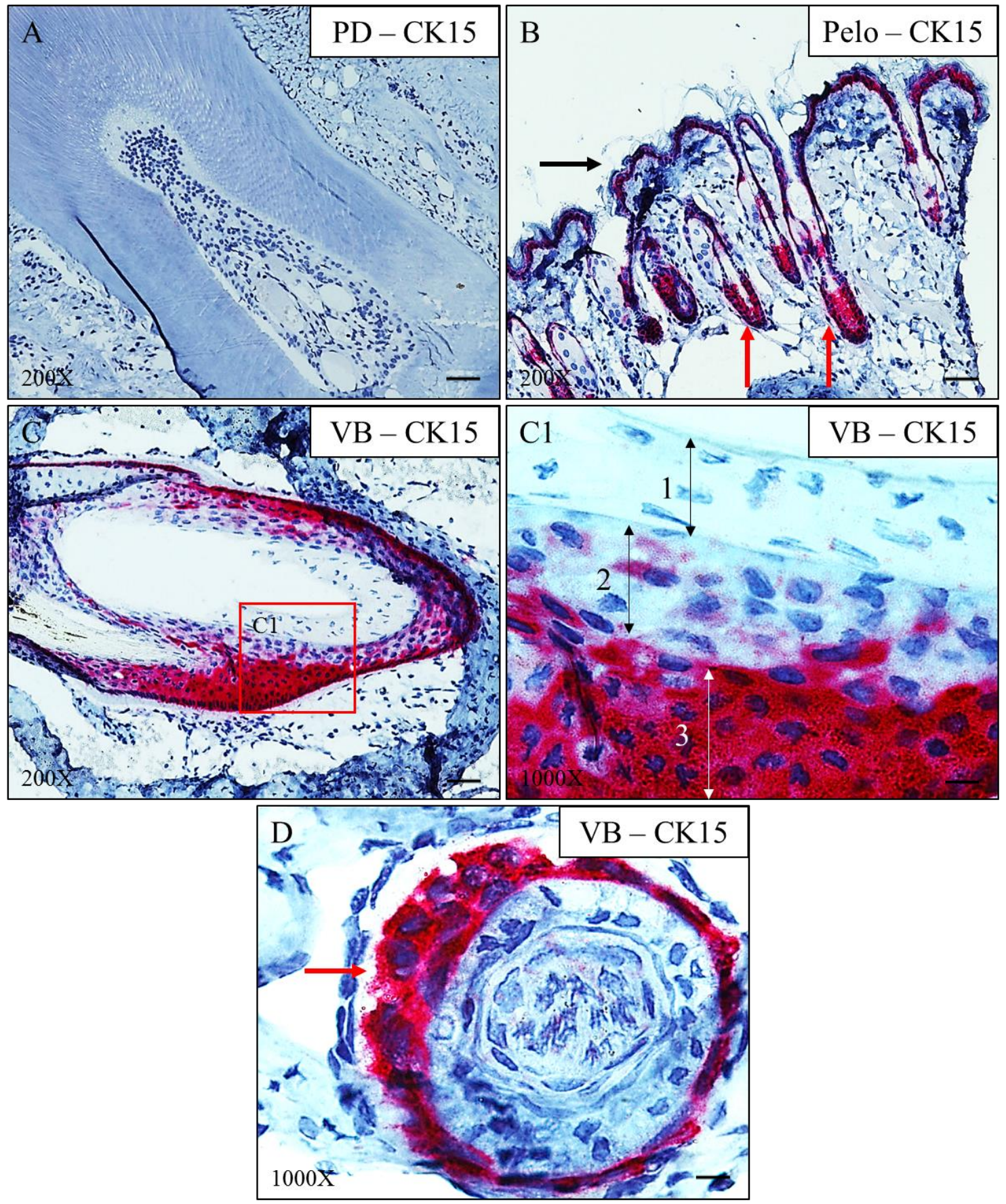

Figura 20 - Imunohistoquímica para Citoqueratina $15 \mathrm{em}$ cortes histológicos de mandíbula e epiderme de focinho de camundongo C57BL6. Em (A) corte sagital de dente, o qual se mostra negativo para Citoqueratina 15. Em (B) positividade para Citoqueratina $15 \mathrm{em}$ pelos (setas vermelhas) e na camada basal da epiderme (seta preta). Em (C) vibrissa marcada positivamente para Citoqueartina 15. Em (C1) é possível se visualizar as diferentes camadas da vibrissa. 1 - Bainha interna. 2 Bainha externa. 3 - Células basais CK15+. Em (D) corte transversal de vibrissa com a bainha externa positiva para CK15. PD - Polpa dentária. VB - Vibrissa. (A - C) $100 \mu \mathrm{m}$, (C1 e D) 20 $\mu \mathrm{m}$. 
Os marcadores específicos para células tronco dos folículos CD34, LGR5, LGR6, LRig1 e Blimp1 também foram avaliados (figuras 21 - 25). A presença destes marcadores foi testada em ambos tecidos onde na polpa dentária LGR5 e LGR6 se mostraram presentes (figuras 22 e 23). As vibrissas foram positivas para todos os marcadores.
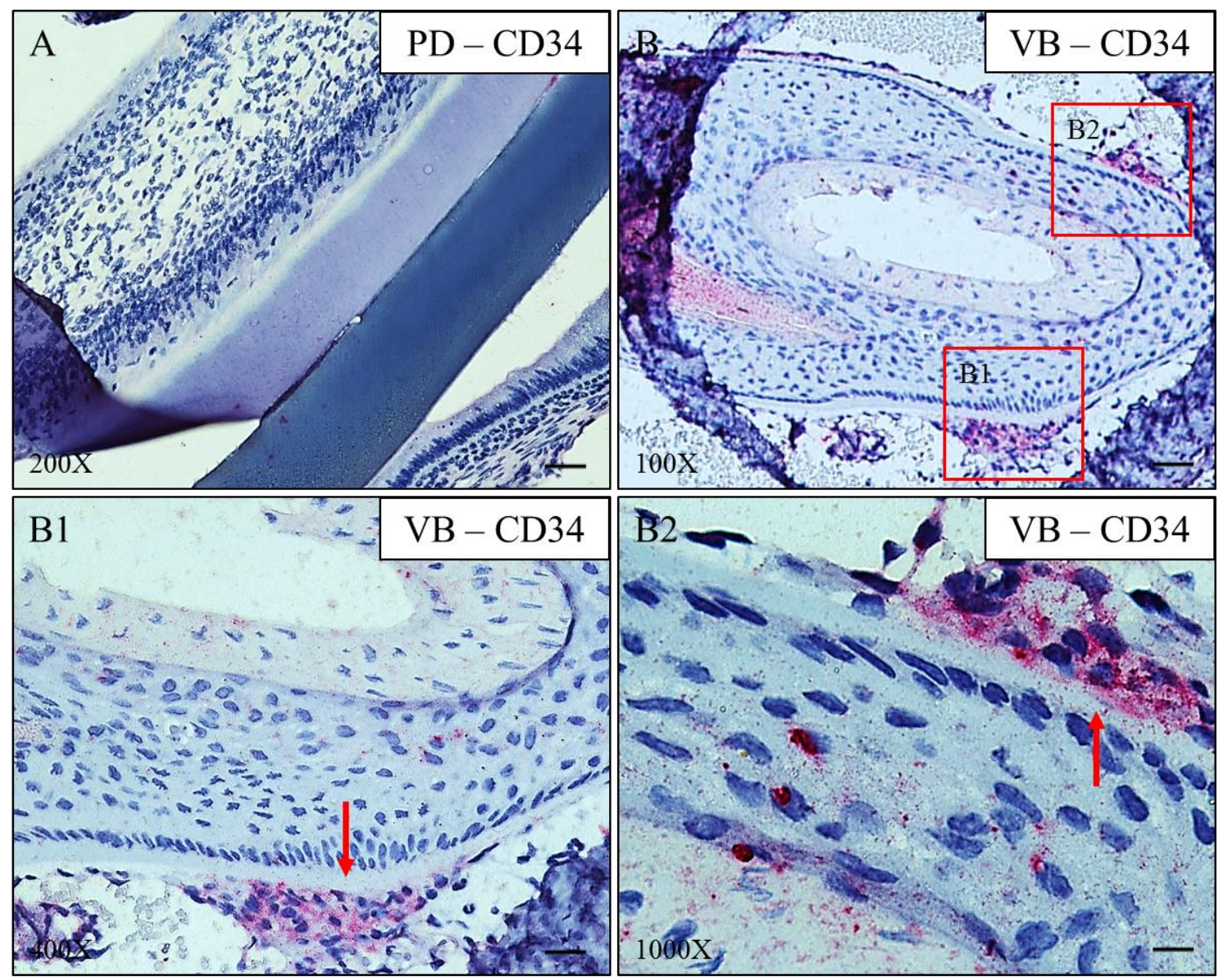

Figura 21 - Imunohistoquímica para CD34 em cortes histológicos de mandíbula e epiderme de focinho de camundongo C57BL6. Em (A) polpa dentária negativa para o marcador CD34. Em (B) pequeno grupo de células marcadas com CD34 (áreas quadriculadas). Em (B1) e (B2) ampliação das áreas quadriculadas em (B). Setas vermelhas indicam células positivas para CD34. PD - Polpa dentária. VB - Vibrissa. Barras: (A) $100 \mu \mathrm{m}$, (B) $200 \mu \mathrm{m}$, (B1) $50 \mu \mathrm{m}$, (B2) $20 \mu \mathrm{m}$. 

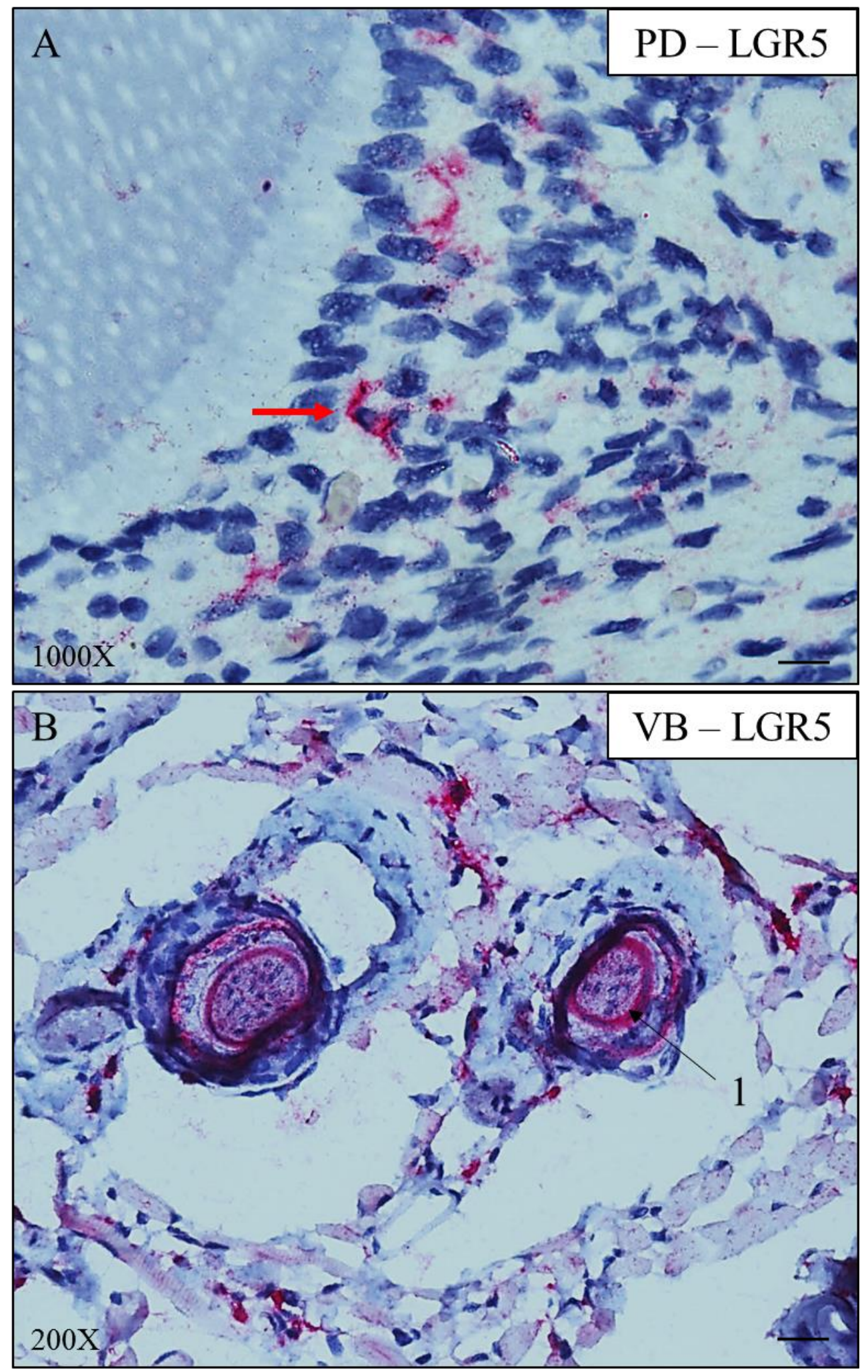

Figura 22 - Imunohistoquímica para LGR5 em cortes histológicos de mandíbula e epiderme de focinho de camundongo C57BL6. Em (A) seta vermelha indica uma célula positiva para o marcador LGR5. Em (B) corte transversal de vibrissas que demonstram positividade para LGR5 na cutícula. PD Polpa dentária. VB - Vibrissa. Barras: (A) $20 \mu \mathrm{m}$, (B) $100 \mu \mathrm{m}$. 




Figura 23 - Imunohistoquímica para LGR6 em cortes histológicos de mandíbula e epiderme de focinho de camundongo C57BL6. Em (A) é possível se observar duas camadas de odontoblastos positivas para LGR6 na polpa dentária (setas vermelhas). Em (B) ameloblastos são positivos para LGR6 (seta vermelha). Em (C) folículos da epiderme e células da própria epiderme se mostram positivos para LGR6. Em (D) vibrissa positiva para LGR6 (seta vermelha). PD - Polpa dentária. VB Vibrissa. Barras: (A) $100 \mu \mathrm{m}$, (B - D) $50 \mu \mathrm{m}$. 


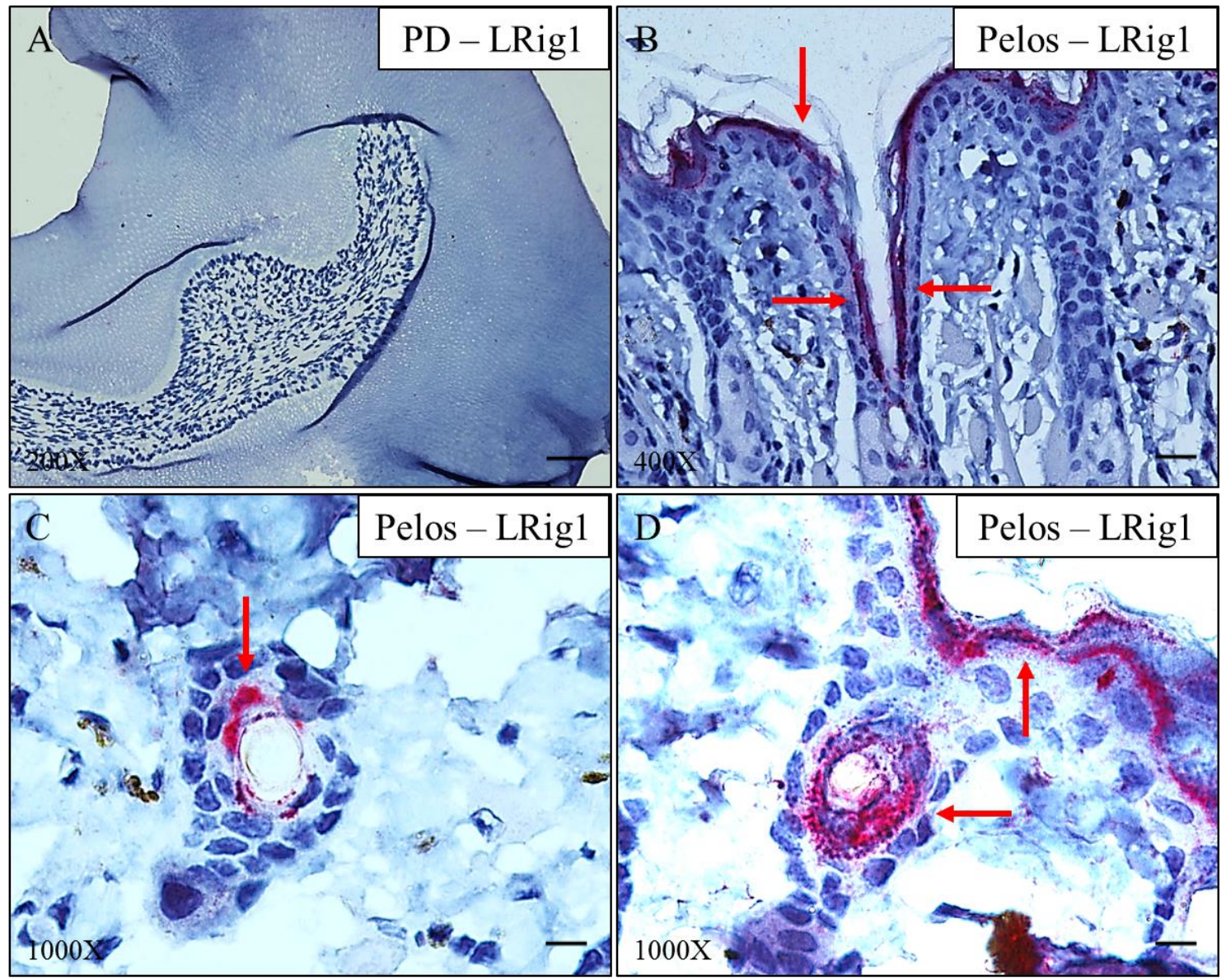

Figura 24 - Imunohistoquímica para LRig1 em cortes histológicos de mandíbula e epiderme de focinho de camundongo C57BL6. Em (A) polpa dentária negativa. Em (B) epiderme marcada em vermelho para LRig1. Notar que a marcação ocorre na bainha interna e na epiderme, mostrando uma continuidade nos tecidos (setas vermelhas). Em (C) células marcadas para LRig1 (seta vermelha). Em (D) membrana basal da epiderme e folículo positivos (setas vermelhas). PD - Polpa dentária. VB - Vibrissa. Barras: (A) $100 \mu \mathrm{m}$, (B) $50 \mu \mathrm{m}$, (C e D) $20 \mu \mathrm{m}$. 



Figura 25 - Imunohistoquímica para Blimp1 em cortes histológicos de mandíbula e epiderme de focinho de camundongo C57BL6. Em (A) polpa dentária negativa para Blimp1. Em (B) seta vermelha indica células da bainha externa positivas para Blimp1. PD - Polpa dentária. VB - Vibrissa. Barras: (A) $100 \mu \mathrm{m}$, (B) $50 \mu \mathrm{m}$. 


\subsection{Obtenção celular a partir da cultura primária de vibrissas e caracterização fenotípica das células isoladas in vitro quanto ao método de isolamento.}

Foram utilizados dois métodos para a obtenção de células a partir das vibrissas. O primeiro método adotado foi o "explante". Neste as vibrissas foram extraídas e dissecadas de forma a preservar os nichos de CT que são: a papila dérmica e o bulge. Após o isolamento as vibrissas foram colocadas em cultura. O segundo método utilizado para o estabelecimento de cultura primária consistiu em submeter as vibrissas isoladas à uma digestão enzimática com colagenase tipo I ou dispase.

O método de explante derivou uma grande quantidade de colônias com células de morfologia fibroblastoíde, as quais apresentaram capacidade de expansão in vitro até a passagem cinco (P5) e até a transferência quatro (T4) mantendo sua morfologia constante. Nas culturas onde as vibrissas passaram por processo de digestão enzimática com colagenase tipo I, se obteve células com morfologia fibroblastoíde, no entanto estas células se diferenciaram espontaneamente nas passagens iniciais (P1 e P2). Por fim, nas culturas onde as vibrissas passaram pelo processo de digestão enzimático com dispase, demonstrou-se uma menor eficiência no isolamento celular, no que se refere a morfologia celular e capacidade de expansão uma vez que foi notada alterações morfológicas nas passagens iniciais (P1 e P2).

Desta forma o estabelecimento das culturas primárias foi realizado pelo método do explante, pois comparando-se com o método por digestão enzimática se observa uma cultura com morfologia fibroblastóide uniforme que se mantem indiferenciada até a passagem quatro (P4). Outra observação feita foi que a digestão enzimática das vibrissas causa um estresse extra nas células, o que pode produzir células diferenciadas na cultura, favorecendo assim a diferenciação das demais células (figura 26). 


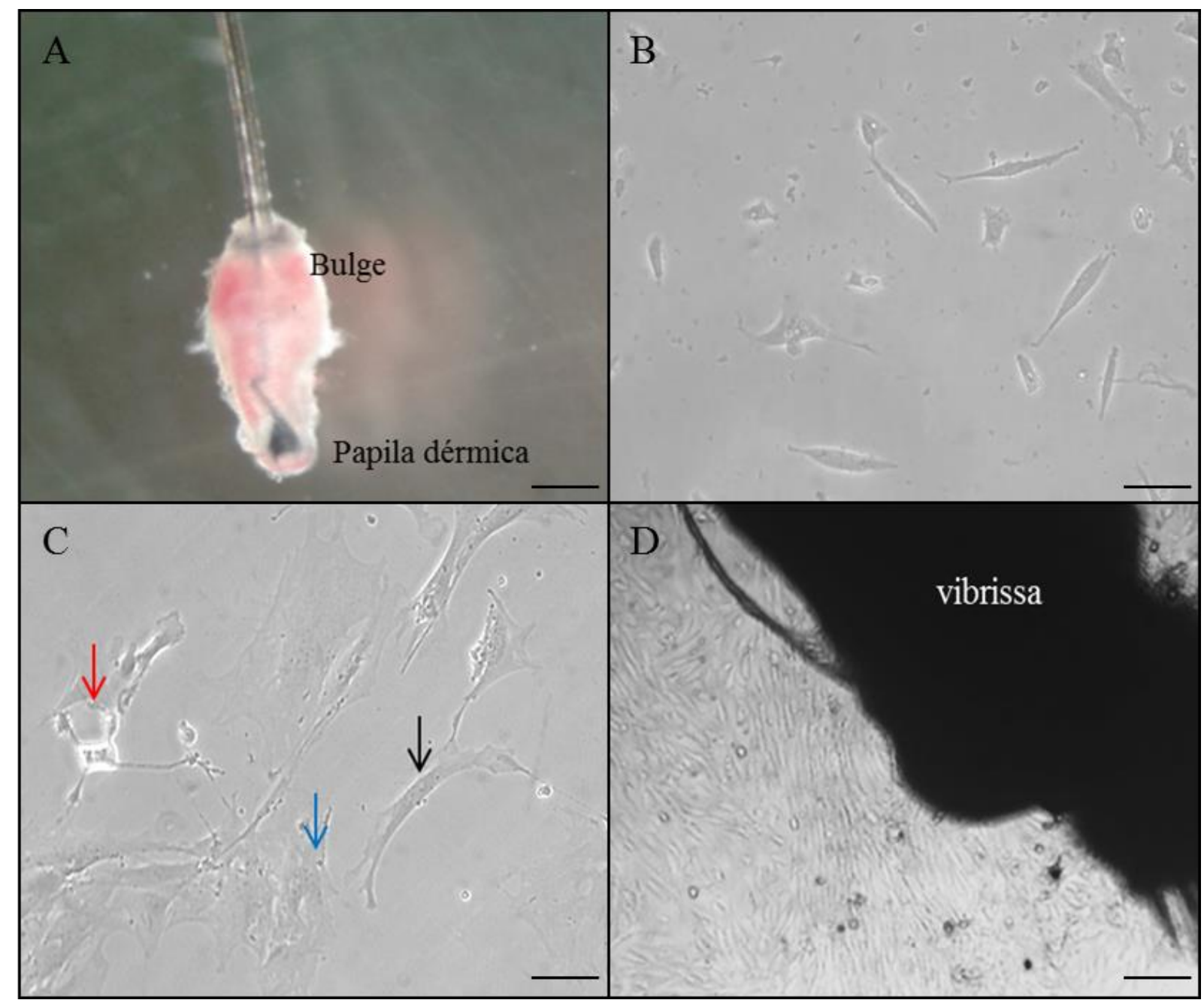

Figura 26 - Métodos de isolamento utilizados para obtenção de células da vibrissa: método químico utilizando digestão com colagenase tipo I (B), dispase (C) e explante (D). Em (A) vibrissa extraída de camundongo vista sob objetiva da lupa. Em (B) nota-se poucas células derivadas a partir do método de digestão por colagenase. Em (C) mix de morfologia celular derivada da digestão por dispase, células com morfolgia epithelial-like (seta azul), fibroblast-like (seta preta) e neuronallike (seta vermelha). Em (D) Demonstramos o "Explante" da vibrissa e a grande quantidade de células liberada pelo fragmento, onde as células apresentam predominantemente morfologia fibroblast-like. (B) e (C) aumento de 400 x. (D) aumento de 200 x. Barras: (A) $500 \mu \mathrm{m}$, (B e C) 20 $\mu \mathrm{m}$, (D) $100 \mu \mathrm{m}$. 


\subsection{Determinação do meio para cultivo primário de vibrissas}

Para o isolamento e expansão das células da vibrissa, adotamos o método de "explante", pois as células isoladas apresentaram morfologia de células indiferenciadas, e maior capacidade de expansão celular, quando comparado com a digestão enzimática. Após a escolha do método, utilizamos diferentes composições de meios de cultivo, a fim de se obter a linhagem de células tronco da vibrissa. Diferentes morfologias celulares foram obtidas ao utilizar os distintos meios de cultivo, bem como a manutenção do estágio diferenciado destas células in vitro. Foram selecionados quatro meios de cultivo de composição distinta, comumente utilizados para o isolamento de células tronco (tabela 1).

Ao utilizar o meio de cultivo Low Glucose e DMEM-F12, observamos um cultivo celular heterogêneo, composto por células com morfologia epitelial (figuras 27A, 27B, 28A), fibroblastoíde (figuras 27A, 28B-C) e neuronal (figuras 27C e 28D). Porém, após o primeiro repique celular, as células cultivadas no meio de cultivo Low Glucose apresentaram alterações morfológicas (figura 27D). Outro diferencial observado foi a capacidade de expansão celular. Ao utilizar o meio Low Glucose as células atingiram confluência de 70\% somente aos 21 dias, enquanto que ao usar o DMEM f-12 a confluência foi atingida entre 7 - 10 dias após o início do cultivo celular (figura 28A).

Durante o processo de expansão celular (entre as passagens p2-p3), algumas morfologias celulares se tornaram predominantes. Ao utilizar o meio de cultivo Low Glucose, as células em cultivo adquiriram preferencialmente a morfologia epithetial-like (figura 27B) e outras se diferenciaram espontaneamente para células de perfil neuronal-like (figura 27C). Enquanto que para o DMEM-F12 esta diferenciação ocorreu um pouco mais tarde entre as passagens 3-4.

Outro meio de cultivo utilizado foi o de IPS (tabela 1), este além de gerar células com morfologia fibroblastóides e epitelial, resultou na formação de esferas (“hair spheres") (YANG; XU, 2013) (figuras 29 A e A'). As células isoladas utilizando este meio de cultivo, se diferenciaram em células com morfologia neural após a segunda passagem in vitro. As vibrissas cultivadas com meio neurobasal foram mantidas por 40 dias, porém não foi observada adesão celular in vitro, desta forma essas culturas foram descartadas (figura 29B). E por fim, frente a esses resultados optou-se pelo uso do meio DMEM-F12 para o cultivo das vibrissas. 


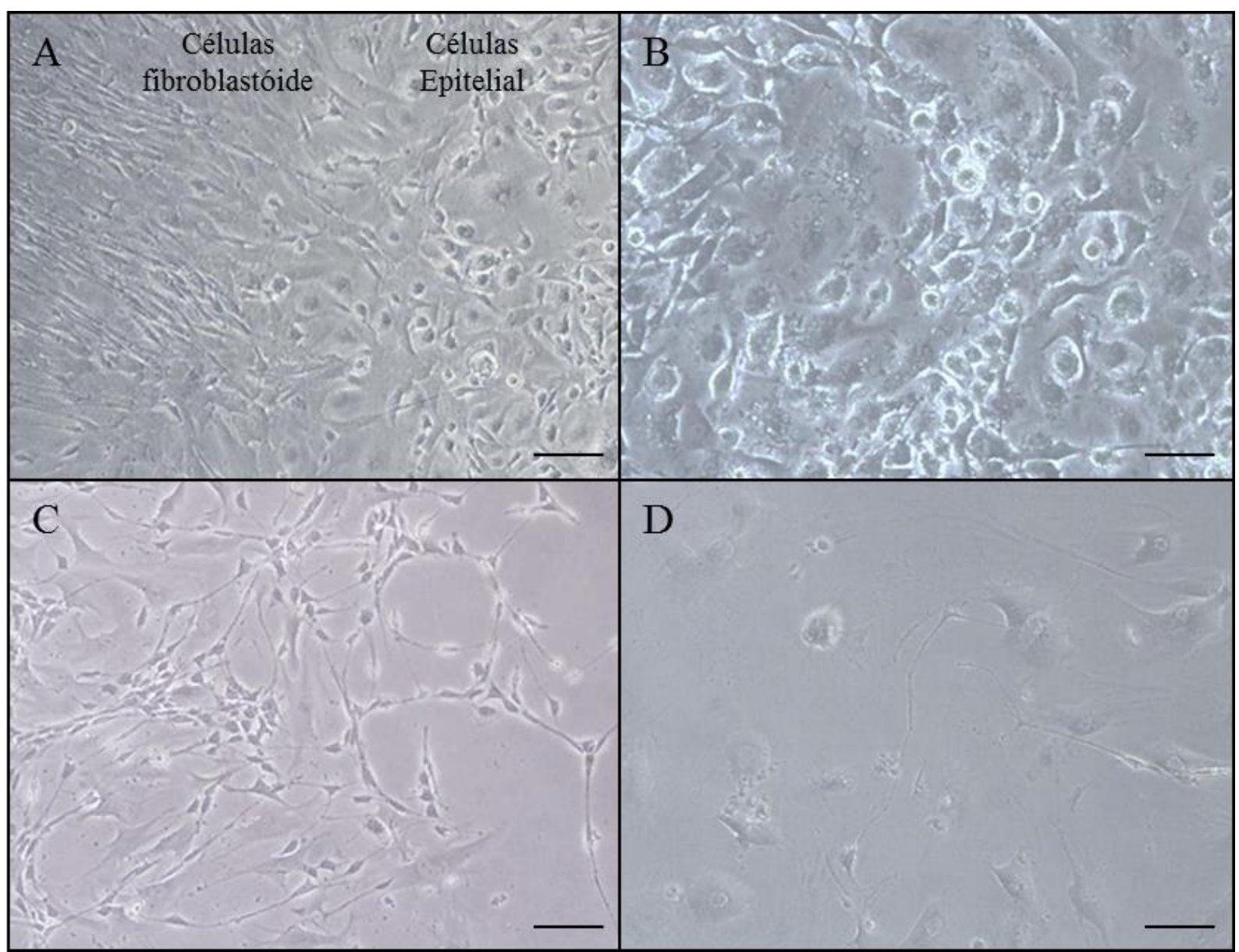

Figura 27 - Diferentes morfologias celulares derivadas do cultivo celular da vibrissa pelo método de "explante" e meio Low glicose. Em (A) células com morfologia fibroblast-like e epithelial-like, $200 \mathrm{x}$. Em (B) um maior aumento de células com morfologia epithelial-like, $400 \mathrm{x}$. Em (C) células com morfologa neuronal-like, 200 x. Em (D) células diferenciadas após o repique celular, 400 x. Barras: (A e C) $100 \mu \mathrm{m},(\mathbf{B}$ e D) $20 \mu \mathrm{m}$. 


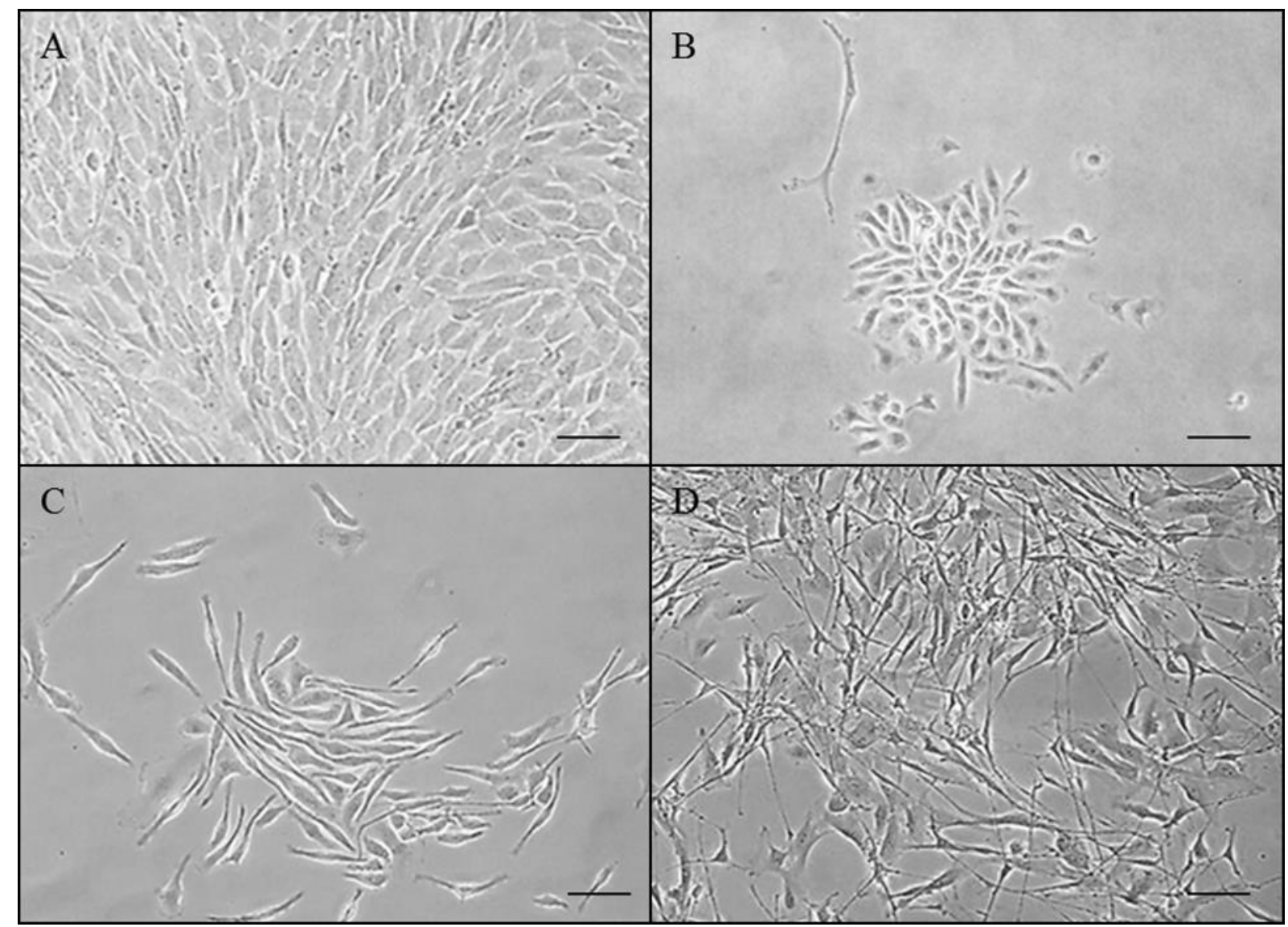

Figura 28 - Diferentes morfologias celulares derivadas do cultivo celular da vibrissa pelo método de "explante" com o meio de cultivo DMEM-F12. Em (A), células com morfologia epithelial-like, com confluência de 80 - $90 \%$ após 10 dias de cultivo celular. 200 x. Em (B) colônia de células mistas com morfologia epithelial-like e fibroblast-like, 200x. Em (C) côlonia com morfologia fibroblastoíde, 200 x. Em (D), células com morfologia neuronal, 200 x. Barras: (A - D) 50 m.

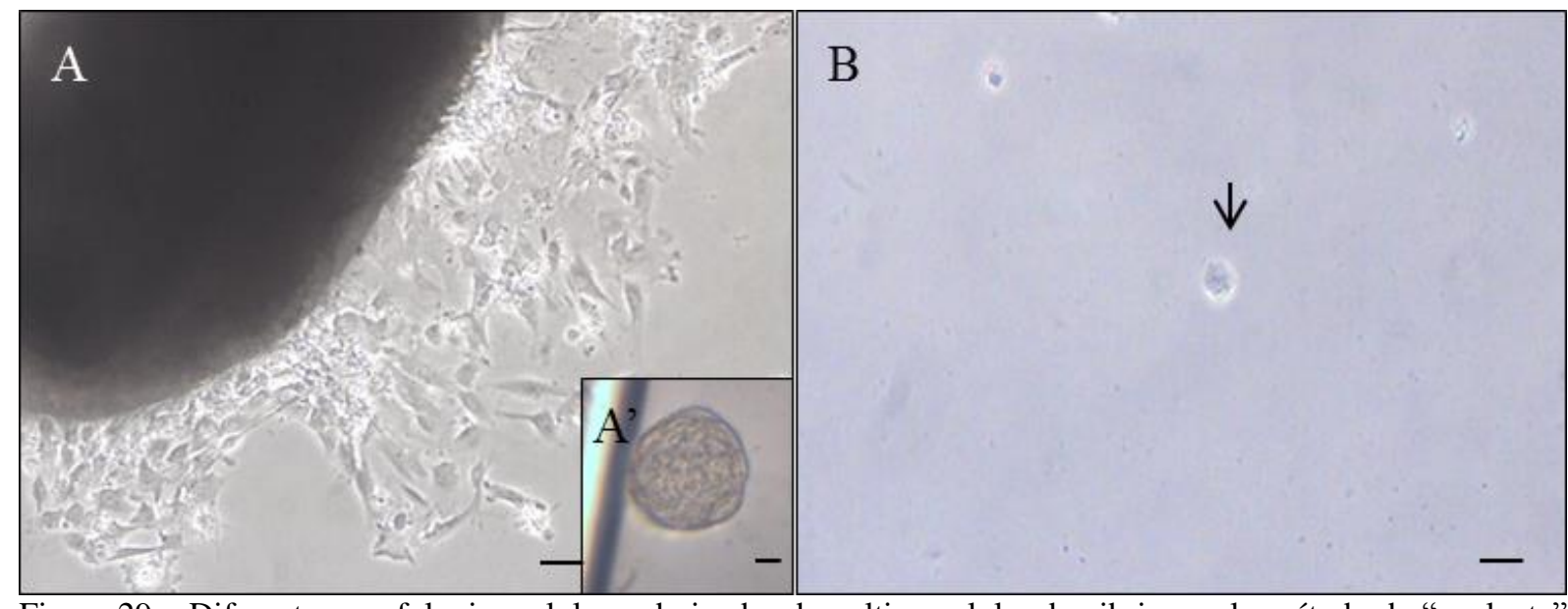

Figura 29 - Diferentes morfologias celulares derivadas do cultivo celular da vibrissa pelo método de "explante" e com o meio de cultivo para IPSC e neurobasal. Em (A) imagem mostra uma população heterogênea de células com morfologia neuronal e fibroblastoíde derivadas do explante $(200 \mathrm{x})$, (400 x). Em (A') "hair espheres". Em (B) demonstramos a ausência de células derivadas do cultivo celular do explante em meio neurobasal. Nota-se raras células não aderidas (seta), 200 x. Barras: (A) $20 \mu \mathrm{m}$, (A') $100 \mu \mathrm{m}$, (B) $20 \mu \mathrm{m}$. 


\subsection{Obtenção celular a partir da polpa dentária e caracterização fenotípica das células isoladas in vitro}

As polpas dentárias foram cultivadas com meio de cultivo DMEM-F12, que é rotineiramente utilizado para o isolamento de células tronco de polpa dentária de mamíferos (tabela 1), sendo já estabelecido pelo nosso grupo de pesquisa (Kerkis et al., 2006). A cultura primária de células isoladas de camundongos atingiu a confluência de $70 \%$ após 20 dias de plaqueamento da polpa dentária. As células derivadas da polpa dentária eram compostas por uma população heterogênea onde foi possível se observar células com morfologia fibroblastóide (figuras 30C, D, E e F) epitelial (figura 30B) e neuronal (figura 30G e H). Assim como visto nas culturas de vibrissa houve diferenciação durante as passagens, onde células de perfil epitetial apareciam com mais frequência nas passagens mais altas (passagens $\mathrm{p} 4-\mathrm{p} 5)$.

Podemos concluir que diferentes tipos de populações celulares podem ser isoladas de ambas as fontes utilizando diferentes métodos e meios de cultivo. Porém, o método do explante se demonstrou mais eficiente no isolamento das células. Um resumo das células utilizadas para a caracterização celular é visto na tabela 2.

Tabela 2 - Células utilizadas para caracterização.

\begin{tabular}{lcccc}
\hline Tecido & Isolamento & $\begin{array}{c}\text { Meio para } \\
\text { cultivo }\end{array}$ & Imunofluorescência & $\begin{array}{c}\text { Citometria de } \\
\text { fluxo }\end{array}$ \\
\hline \hline Vibrissa & Explante & DMEM-F12 & Passagem (P0) & Passagem (P2) \\
\hline \hline Polpa dentária & Explante & DMEM-F12 & Passagem (P1) & Passagem (P4) \\
\hline \hline
\end{tabular}




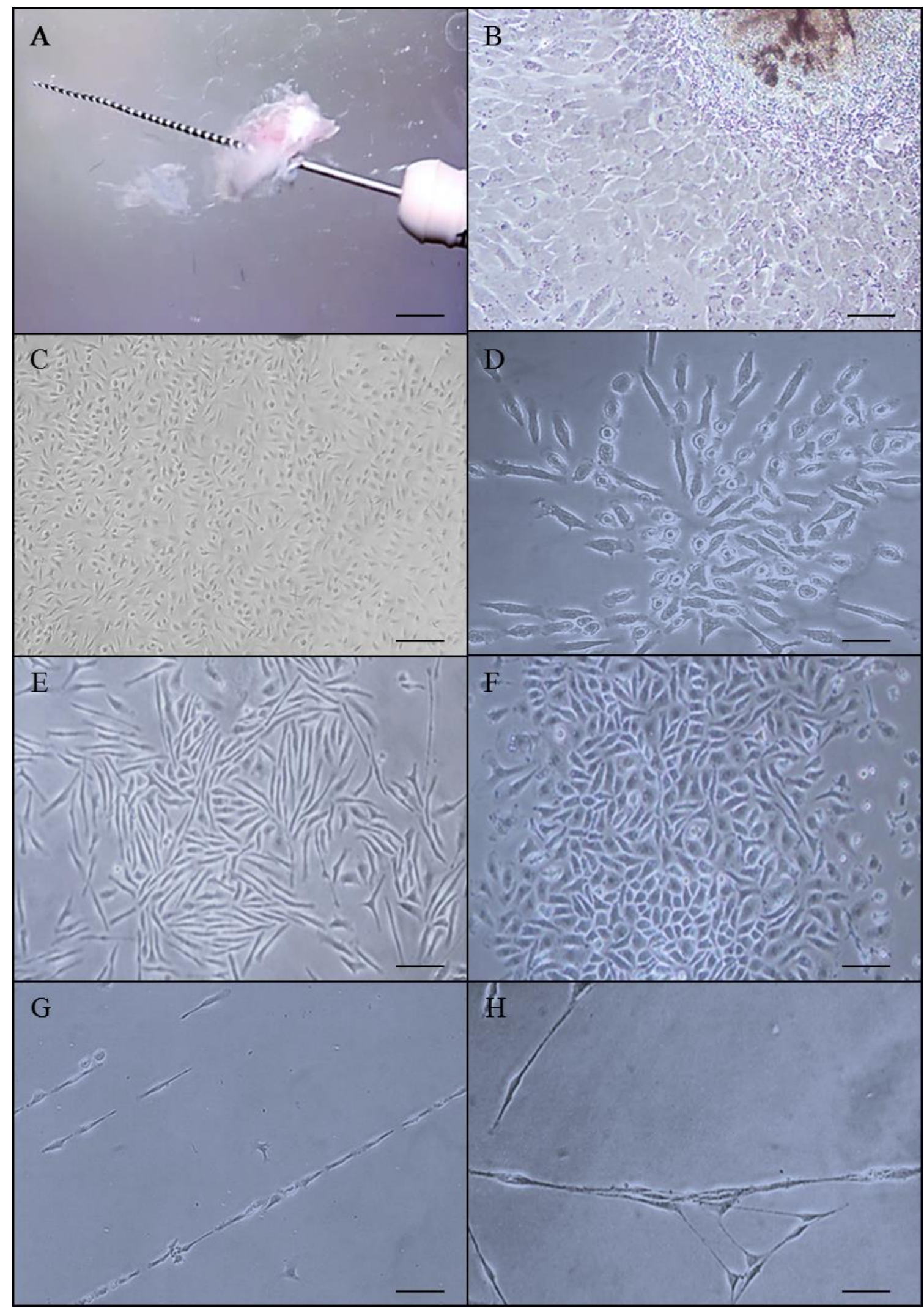

Figura 30 - Cultivo primário da polpa dentária de camundongo e as diferentes morfologias celulares derivadas do explante do tecido mantida no meio DMEM-12 na passagem 1 (P1). Em (A) polpa dentária extraída de camundongo com auxílio de lima vista sob objetiva da lupa. Em (B) células com morfologia epitelial, $200 \mathrm{x}$. Em (C), (D), (E) e (F) células com morfologia fibroblastóide, (C, 100 x) (D, E e F, 200 x). Em (G) e (H) células com morfologia neuronal, 200 x e 400 x. Barras: (A) $500 \mu \mathrm{m}$, (B) $50 \mu \mathrm{m}$, (C) $100 \mu \mathrm{m}$, (D) $20 \mu \mathrm{m},(\mathbf{E}-\mathbf{H}) 50 \mu \mathrm{m}$. 


\subsection{Caracterização in vitro da expressão de marcadores imunofenotípicos para células tronco de vibrissa e polpa dentária utilizando os métodos de imunofluorescência e citometria de fluxo.}

Para a caracterização das células da vibrissa e da polpa dentária utilizamos um grande painel de marcadores, que inclui marcadores de células tronco da crista neural (Ckit), de progenitores neuronais (Nestina), de células tronco pluripotentes (Oct4, Nanog e Sox2), de CTM (CD73, CD90 e CD105), de células tronco epidermais (CK15 e Integrina a6) e de células tronco do folículo piloso (CD34, Blimp1, LGR5, LGR6 e Lrig1). A passagem das células utilizadas nestes experimentos consta na tabela 2 .

Os resultados de imunocitofluorescência e citometria de fluxo demonstram que a expressão do marcador de células tronco da crista neural (Ckit) foi positiva em ambos os tecidos, sendo possível visualizar esta marcação no citoplasma das células (figura 31). Nestina que é um filamento intermediário comumente expresso em células progenitoras neuronais foi observado nas culturas de vibrissas por imunofluorescência e também no ensaio de citometria de fluxo, porém nas culturas de polpa dentária não houve marcação para Nestina no ensaio de imunofluorescência, mas no ensaio de citometria de fluxo se observa uma pequena população positiva.

As células isoladas da vibrissa in vitro foram imunopositivas para os anticorpos Oct4 (figura 33), Nanog (figura 34) e Sox2 (figura 35) tanto pela técnica de imunohistoquímica quanto pela citometria de fluxo. As análises de imunocitofluorescência demonstraram que poucas células da polpa dentária foram imunopositivas para os fatores de transcrição Nanog e Sox2. Em ambos os tipos celulares isolados in vitro, a imunomarcação para os três fatores de transcrição ocorreu na região perinuclear. A marcação para os fatores de transcrição foi melhor evidenciada através da técnica de citometria de fluxo. Em todos os gráficos foi possível visualizar marcação, mesmo com baixo índice, para os três fatores de transcrição (figura 33 - 35).

Para os marcadores de CTM observamos uma variabilidade na expressão entre os anticorpos CD73, CD90 e CD105 (figuras 36 - 38). O ensaio de imunocitofluorescência revelou a imunopositividade no citoplasma para os anticorpos CD73, CD90 e CD105 nas células derivadas in vitro da vibrissa e polpa dentária. As análises por citometria de fluxo demonstraram uma grande quantidade de células imunopositivas para estes três marcadores. 
Para se evidenciar possíveis células tronco da epiderme nas culturas utilizou-se os anticorpos Integrina $\alpha 6$ (figura 39) e CK15 (figura 40). Tanto as culturas de vibrissas e polpa dentária apresentaram forte marcação para o marcador Integrina $\alpha 6$ em ambos ensaios de imunocitomarcação e citometria de fluxo. A presença de citoqueratina 15 (CK15) foi observada apenas nas culturas de vibrissas.

Nos folículos são encontrados diversos subgrupos de células tronco. O primeiro subgrupo é o de células $\mathrm{CD}^{+} 4^{+}$que estão localizadas no bulge de folículos. Em ambas culturas houve positividade para o marcador CD34 (figura 41). Outro marcador associado a células tronco dos folículos é o LGR5 que in vitro se mostrou presente tanto na cultura de vibrissas quanto na cultura de polpa dentária (figura 42). Fora da região do bulge temos um subgrupo de células tronco que expressam o marcador LGR6. Houve intensa imunomarcação deste marcador no citoplasma das células de ambas as culturas (figura 43). No istmo, que é a porção final do folículo tem-se células tronco positivas para o marcador LRig1. No ensaio de imunofluorescência e de citometria de fluxo realizado nas duas culturas foi possível visualizar positividade para este marcador (figura 44) em especial na figura 44B (seta azul) onde é possível observar uma célula positiva para LRig1 em processo de divisão assimétrica, no qual uma célula é $\operatorname{LRig} 1^{+}$e a outra, possivelmente é Scd1 ${ }^{+}$. Por fim, um subgrupo de células tronco do folículo expressa o marcador Blimp1. Estas células estão envolvidas na manutenção das glândulas sebáceas e nas culturas foi possível se observar algumas células Blimp1+ (figura $45)$. 
POLPA DENTÁRIA
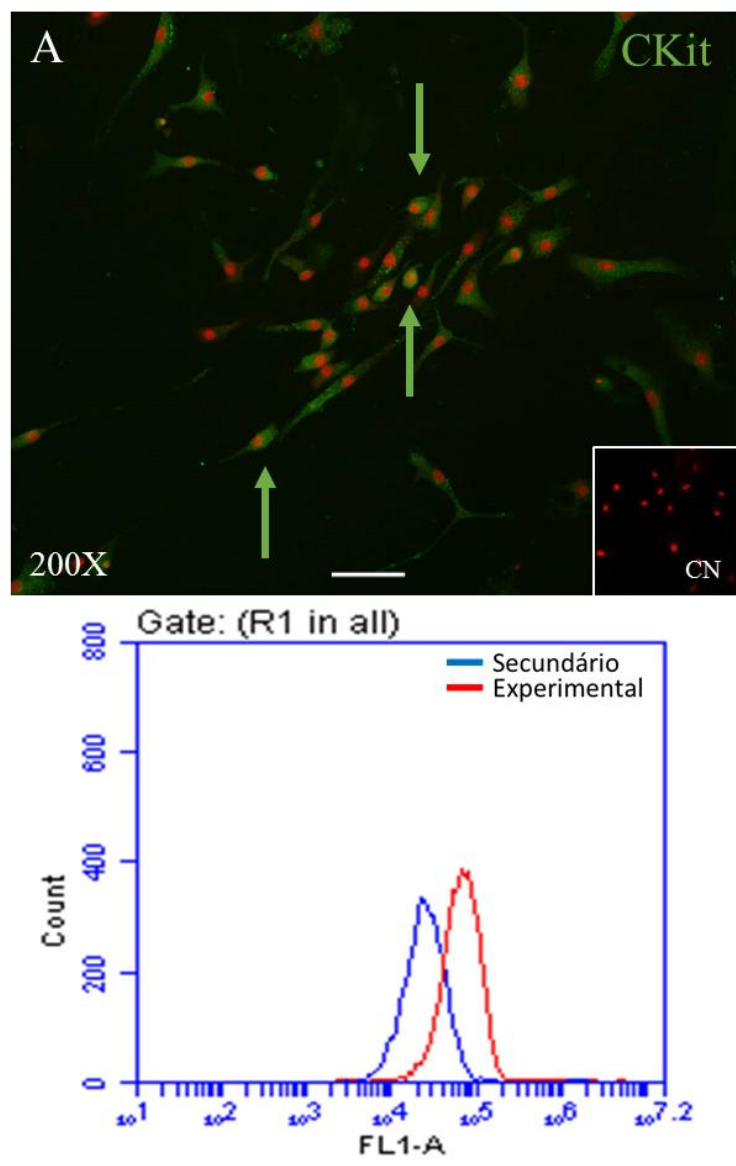

$\underline{\text { VIBRISSA }}$
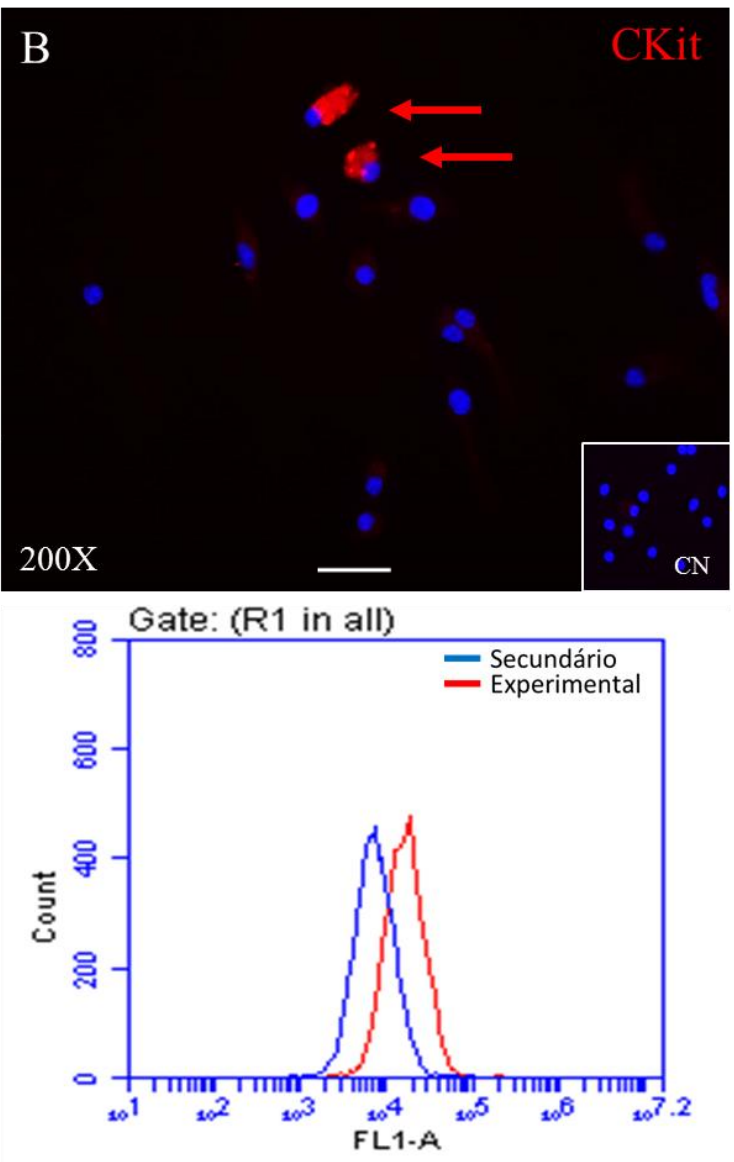

\section{c-Kit}



Figura 31 - Imunofluorescência e citometria de fluxo para CKit. Em (A) células de polpa dentária positivas para CKit (seta verde), logo abaixo citometria de fluxo de células isoladas de polpa dentária demostrando presença de células $\mathrm{Ckit}^{+}$. Em (B) células de vibrissaas positivas para CKit (seta vermelha), logo abaixo citometria de fluxo de células isoladas de vibrissas demostrando presença de células $\mathrm{Ckit}^{+}$. $\mathbf{C N}$ corresponde ao controle negativo de cada reação. Gráfico de barras mostra a média de fluorescência entre as duas culturas (polpa dentária e vibrissas) calculada pelo teste $\mathrm{t}$ de Student. Barras: (A e B) $50 \mu \mathrm{m}$. 
POLPA DENTÁRIA


VIBRISSA
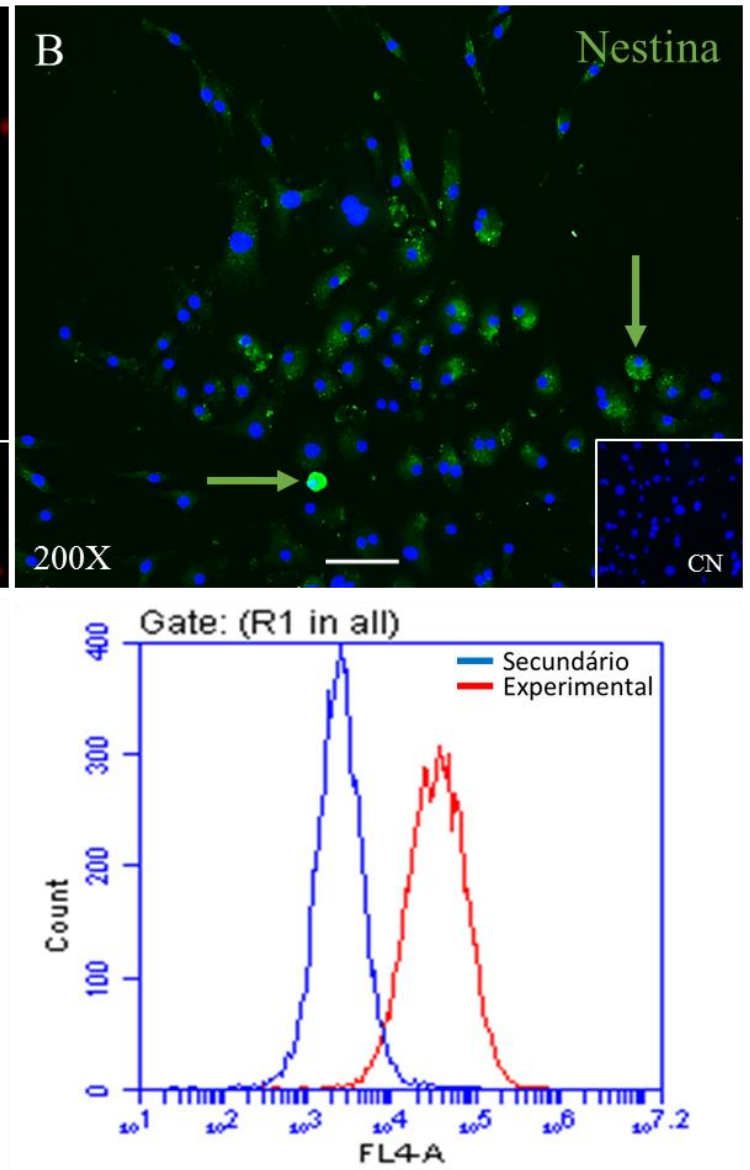

Nestina

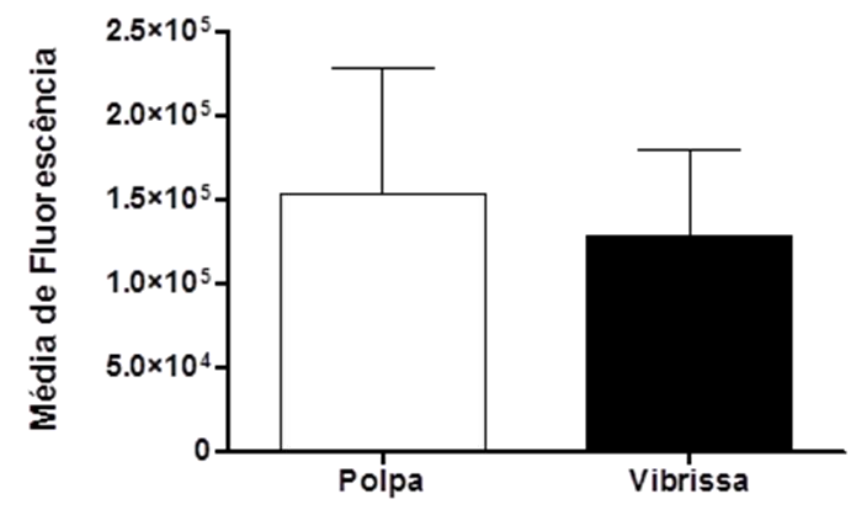

Figura 32 - Imunofluorescência e citometria de fluxo para Nestina. Em (A) células de polpa dentária negativas para Nestina. Seta vermelha evidencia célula em divisão celular. Logo abaixo citometria de fluxo de células isoladas de polpa dentária demostrando presença de raras células Nestina ${ }^{+}$. Em (B) células de vibrissas positivas para Nestina (seta verde), logo abaixo citometria de fluxo de células isoladas de vibrissa demostrando presença de células $\mathrm{Nestina}^{+}$. CN corresponde ao controle negativo de cada reação. Gráfico de barras mostra a média de fluorescência entre as duas culturas (polpa dentária e vibrissas) calculada pelo teste t de Student. Barras: (A e B) $50 \mu \mathrm{m}$. 
POLPA DENTÁRIA


VIBRISSA
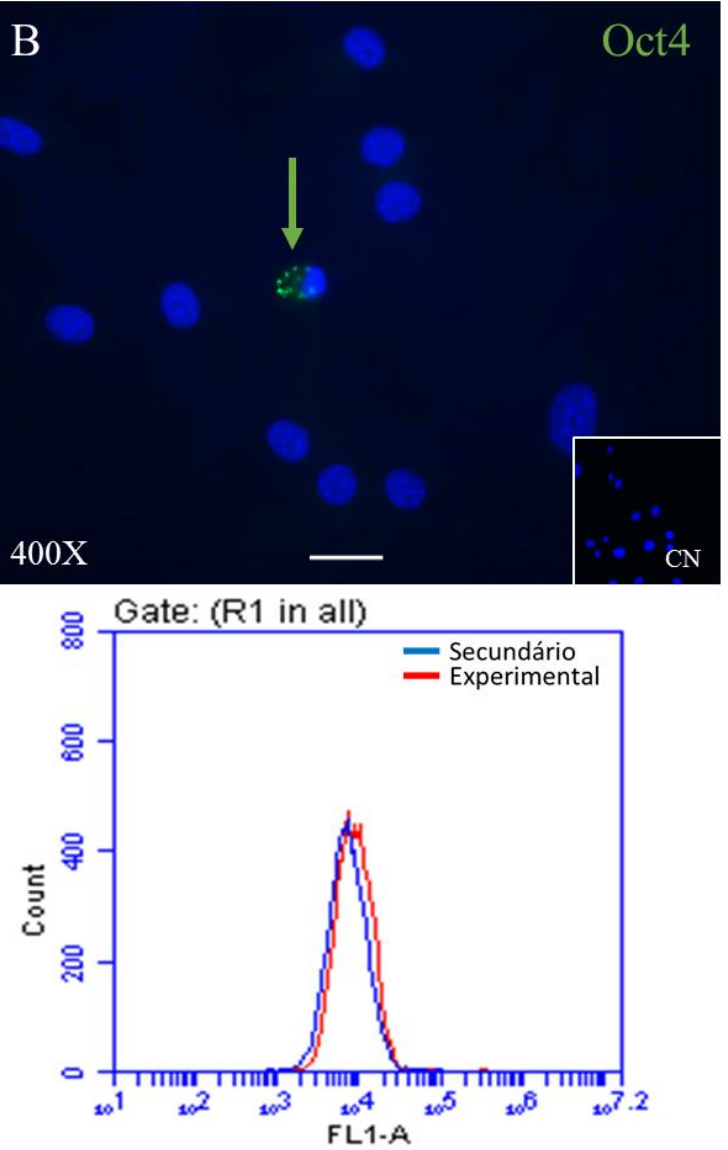

\section{Oct-4}



Figura 33 - Imunofluorescência e citometria de fluxo para Oct4. Em (A) células de polpa dentária negativas para Oct4, logo abaixo citometria de fluxo de células isoladas de polpa dentária demostrando ausência de células $\mathrm{Oct}^{+}$. Em (B) célula de vibrissa positiva para Oct4 (seta verde), logo abaixo citometria de fluxo de células isoladas de vibrissas demostrando presença de células Oct4 ${ }^{+}$. $\mathbf{C N}$ corresponde ao controle negativo de cada reação. Gráfico de barras mostra a média de fluorescência entre as duas culturas (polpa dentária e vibrissas) calculada pelo teste t de Student. Barras: (A) $50 \mu \mathrm{m}$, (B) $20 \mu \mathrm{m}$. 

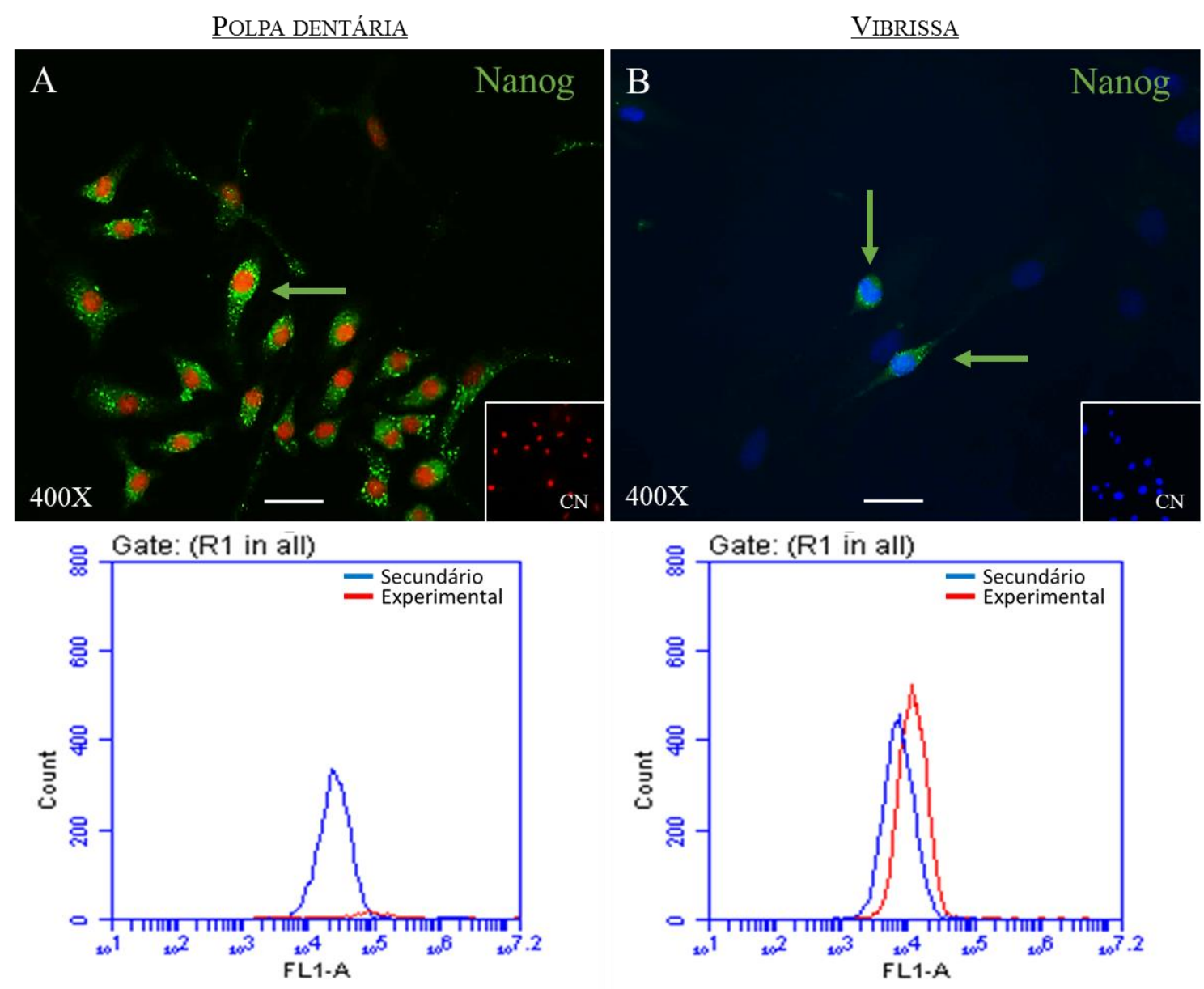

\section{Nanog}

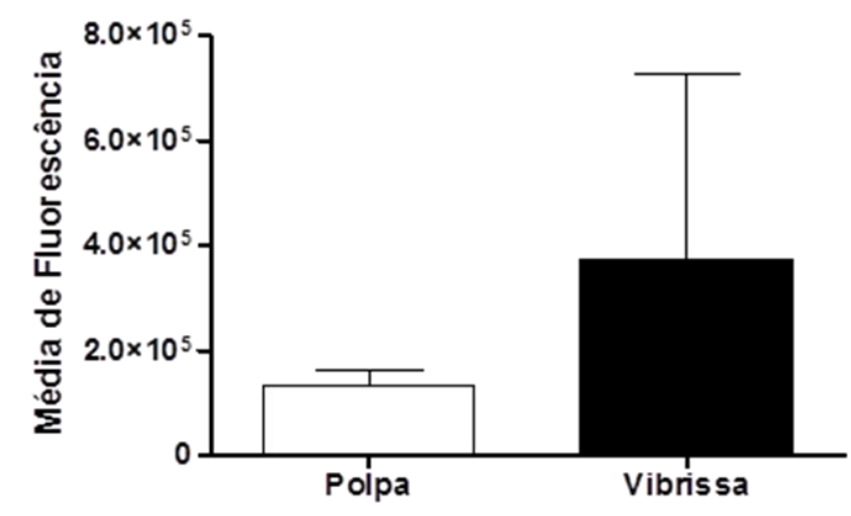

Figura 34 - Imunofluorescência e citometria de fluxo para Nanog. Em (A) células de polpa dentária positivas para Nanog (seta verde), logo abaixo citometria de fluxo de células isoladas de polpa dentária demostrando presença de células $\mathrm{Nanog}^{+}$. Em (B) célula de vibrissa positiva para Nanog (setas verdes), logo abaixo citometria de fluxo de células isoladas de vibrissas demostrando presença de células Nanog ${ }^{+}$. CN corresponde ao controle negativo de cada reação. Gráfico de barras mostra a média de fluorescência entre as duas culturas (polpa dentária e vibrissas) calculada pelo teste $t$ de Student. Barras: (A e B) $50 \mu \mathrm{m}$. 
POLPA DENTÁRIA
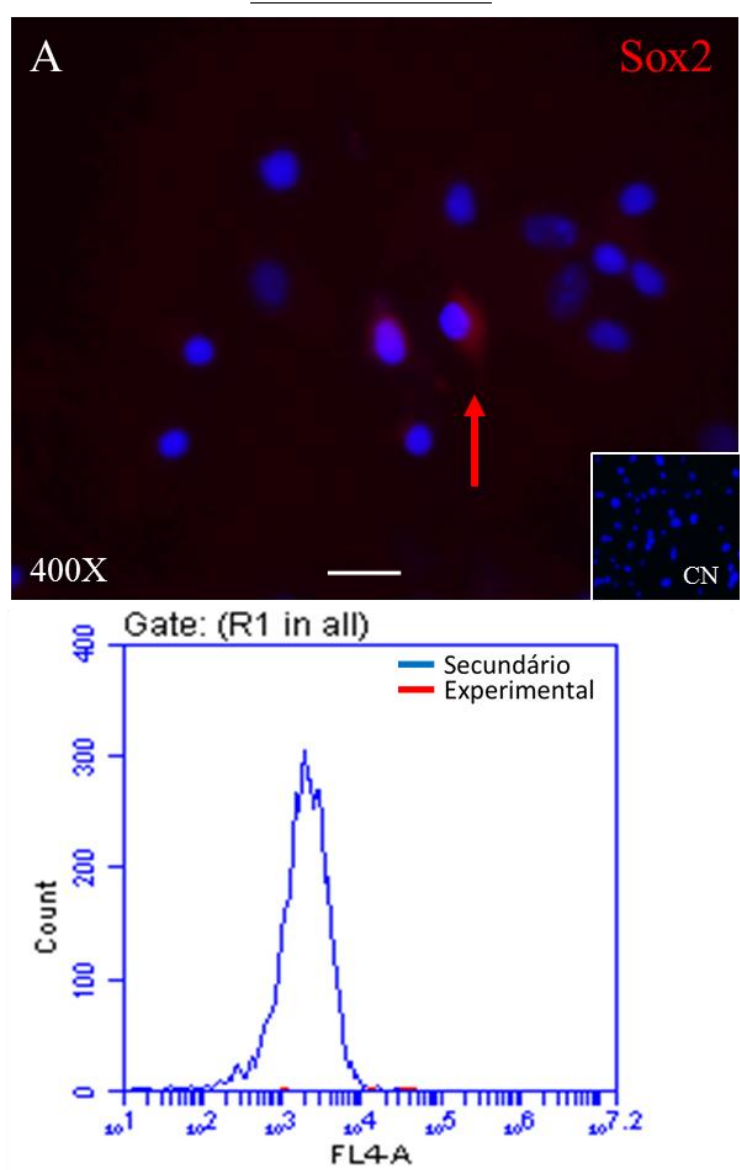

VIBRISSA
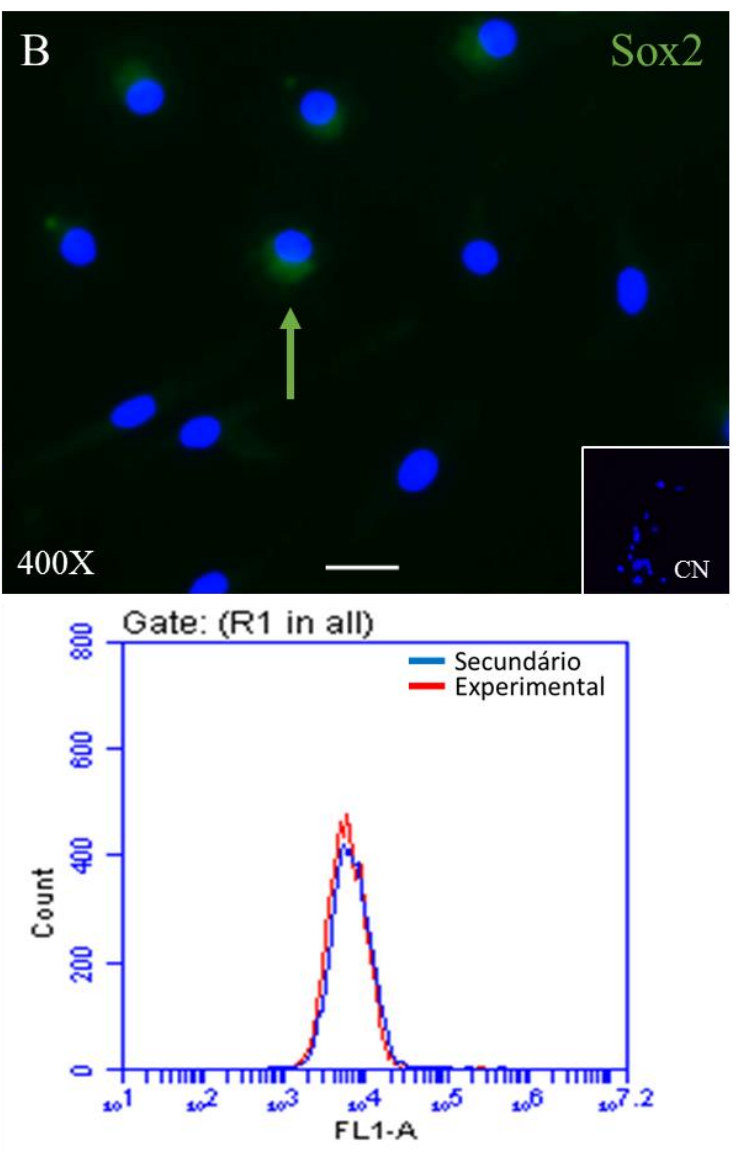

\section{sox 2}

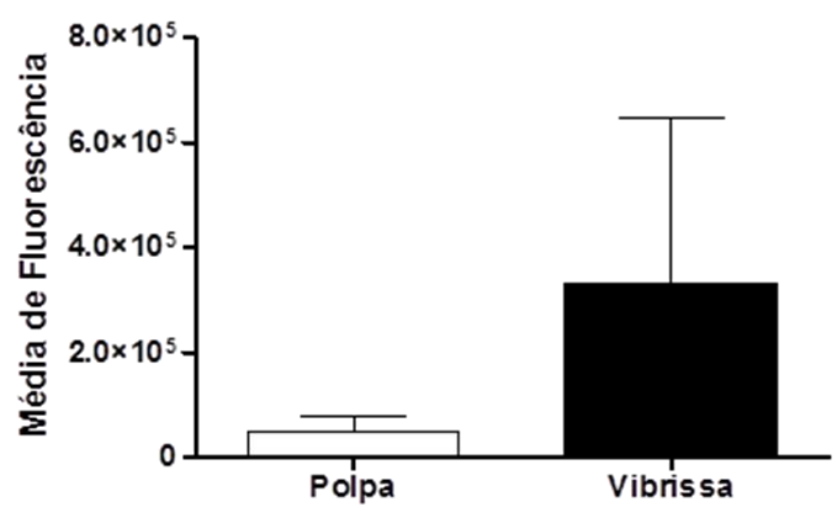

Figura 35 - Imunofluorescência e citometria de fluxo para Sox2. Em (A) células de polpa dentária positivas para Sox2 (seta vermelha), logo abaixo citometria de fluxo de células isoladas de polpa dentária demostrando ausência de células Sox $2^{+}$. Em (B) célula de vibrissa positiva para Sox2 (seta verde), logo abaixo citometria de fluxo de células isoladas de vibrissas demostrando presença de células Sox $2^{+}$. CN corresponde ao controle negativo de cada reação. Gráfico de barras mostra a média de fluorescência entre as duas culturas (polpa dentária e vibrissas) calculada pelo teste t de Student. Barras: (A e B) $20 \mu \mathrm{m}$. 
POLPA DENTÁRIA


VIBRISSA
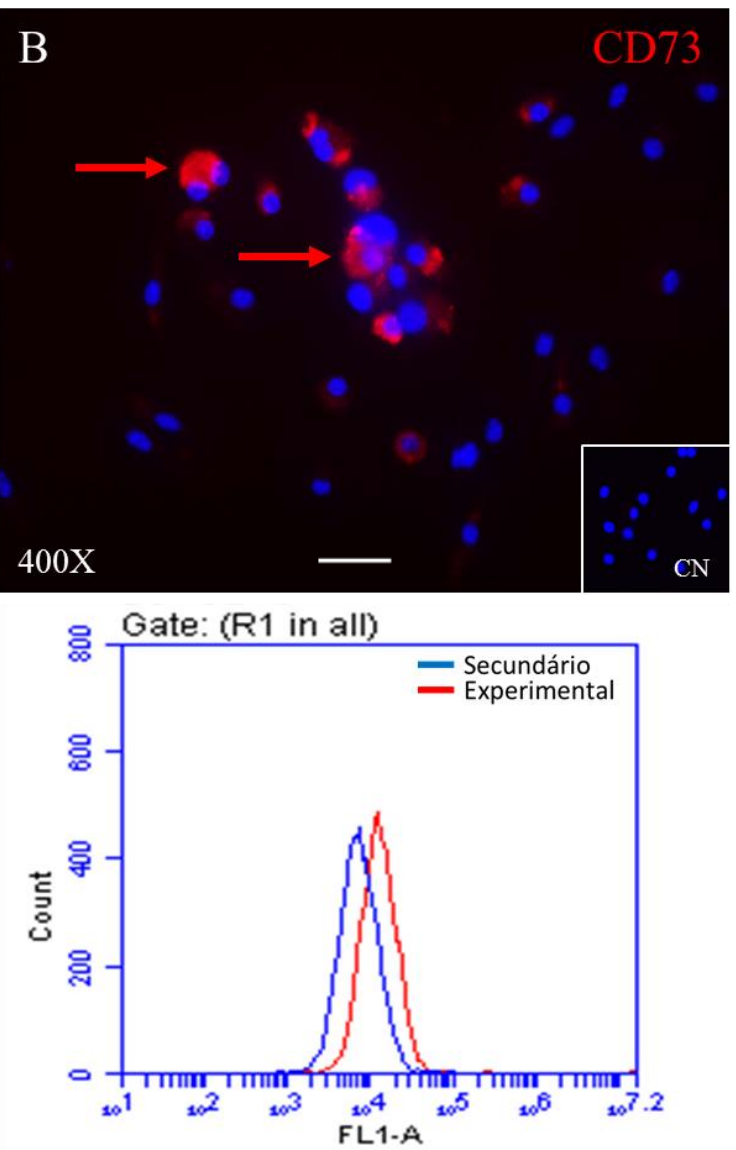

CD 73

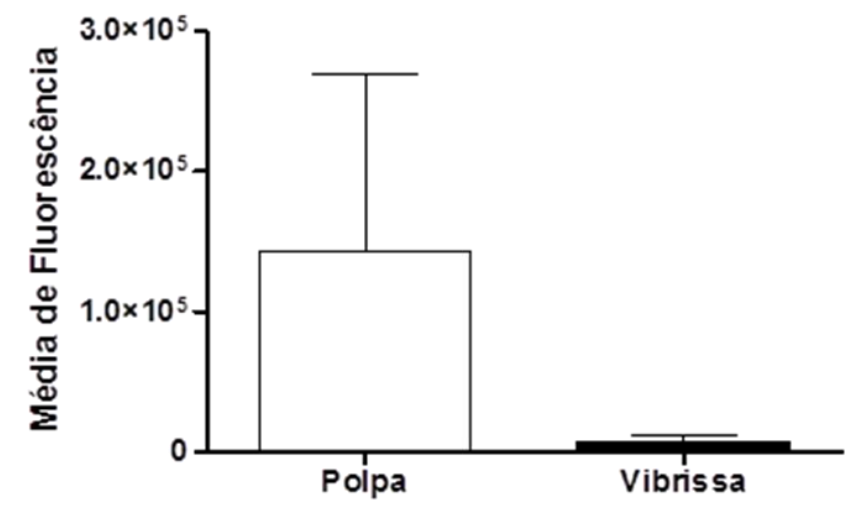

Figura 36 - Imunofluorescência e citometria de fluxo para CD73. Em (A) células de polpa dentária positivas para CD73 (setas verdes), logo abaixo citometria de fluxo de células isoladas de polpa dentária demostrando presença de células $\mathrm{CD}^{+}$. Em (B) células de vibrissa positiva para CD73 (setas vermelhas), logo abaixo citometria de fluxo de células isoladas de vibrissas demostrando presença de células $\mathrm{CD} 73^{+}$. $\mathbf{C N}$ corresponde ao controle negativo de cada reação. Gráfico de barras mostra a média de fluorescência entre as duas culturas (polpa dentária e vibrissas) calculada pelo teste $\mathrm{t}$ de Student. Barras: (A e B) $15 \mu \mathrm{m}$. 
POLPA DENTÁRIA
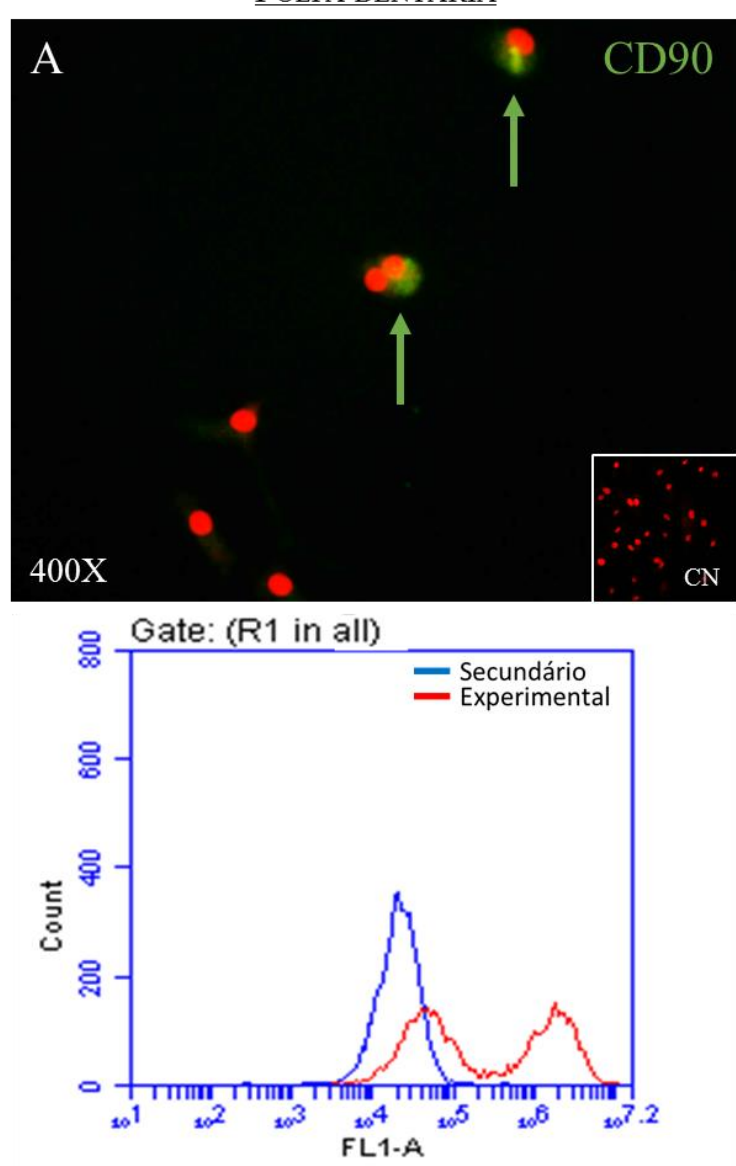

VIBRISSA
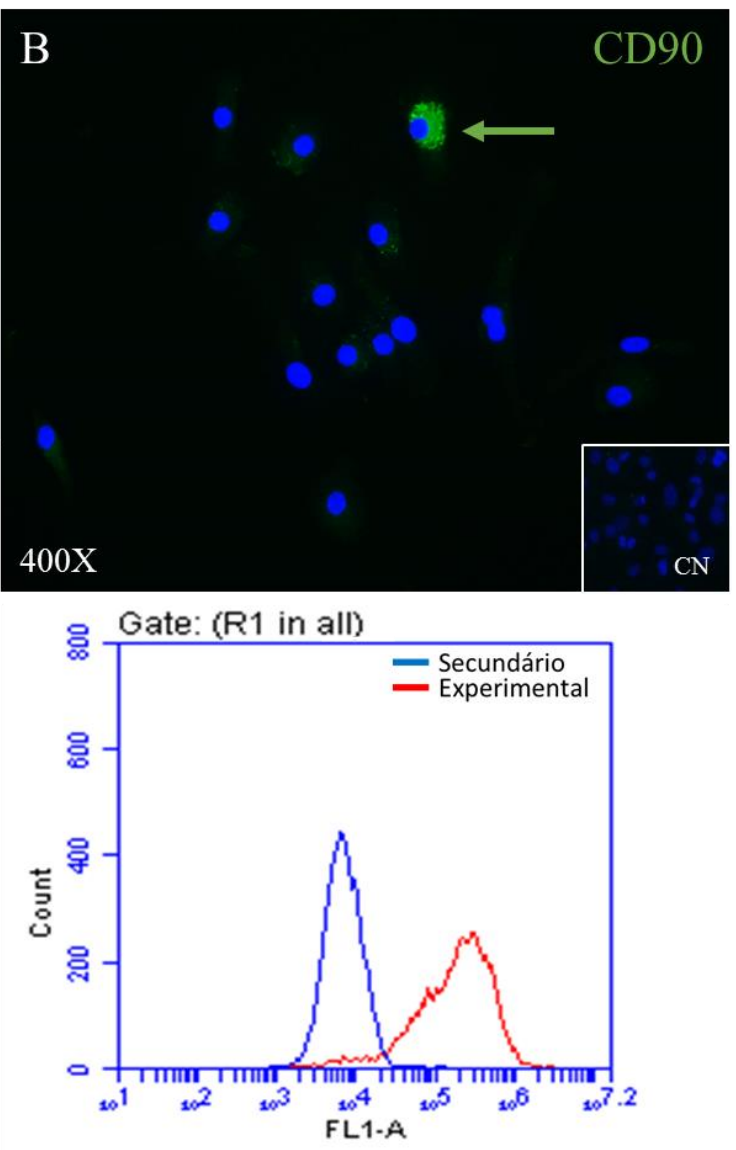

CD 90

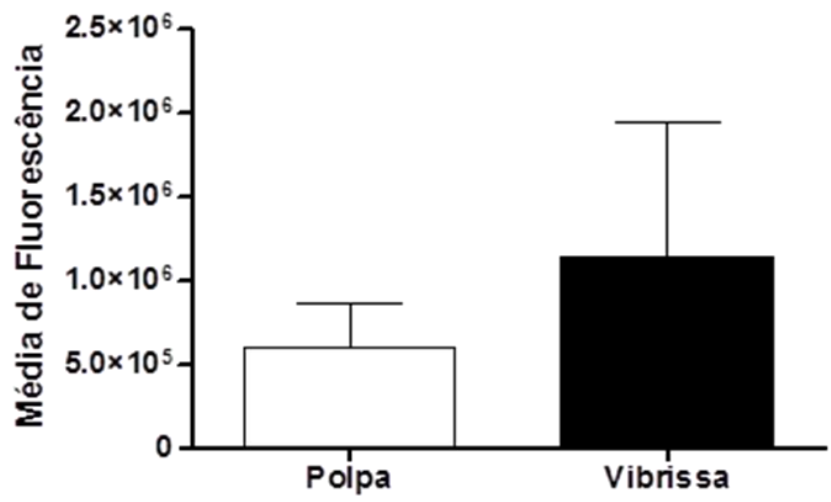

Figura 37 - Imunofluorescência e citometria de fluxo para CD90. Em (A) células de polpa dentária positivas para CD90 (setas verdes), logo abaixo citometria de fluxo de células isoladas de polpa dentária demostrando presença de células CD90+. Em (B) célula de vibrissa positiva para CD90 (seta verde), logo abaixo citometria de fluxo de células isoladas de vibrissas demostrando presença de células $\mathrm{CD} 0^{+}$. CN corresponde ao controle negativo de cada reação. Gráfico de barras mostra a média de fluorescência entre as duas culturas (polpa dentária e vibrissas) calculada pelo teste t de Student. Barras: (A e B) $20 \mu \mathrm{m}$. 
POLPA DENTÁRIA
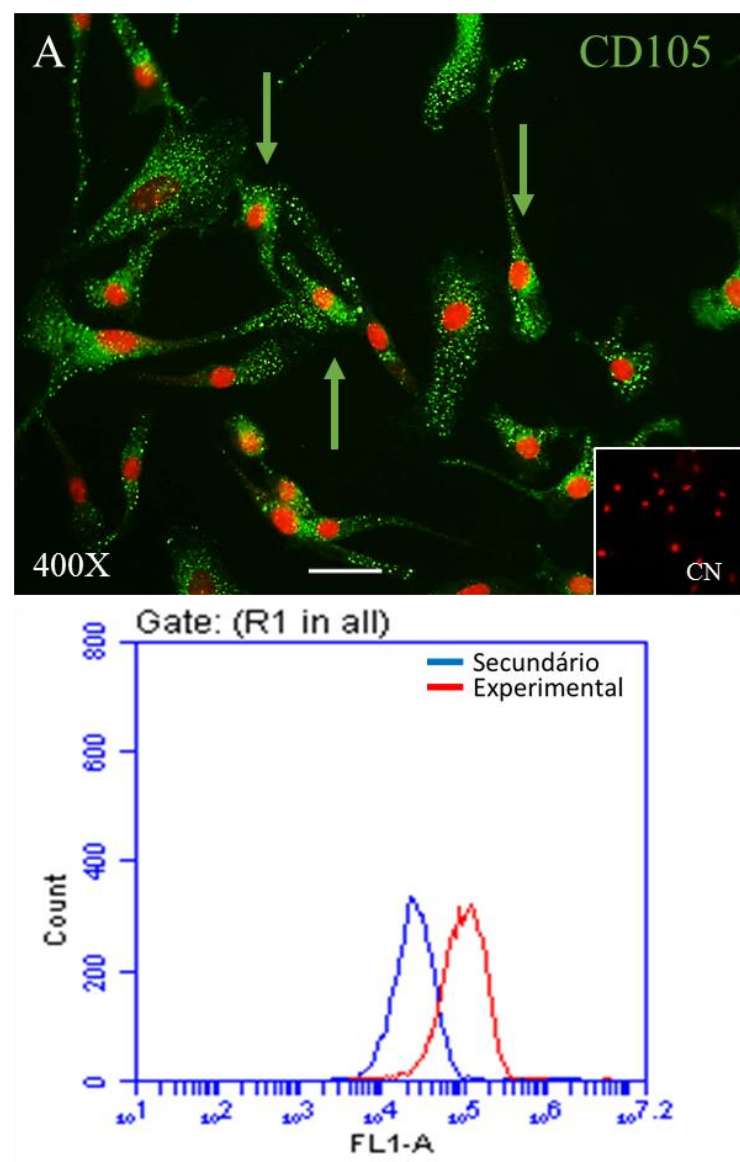

VIBRISSA
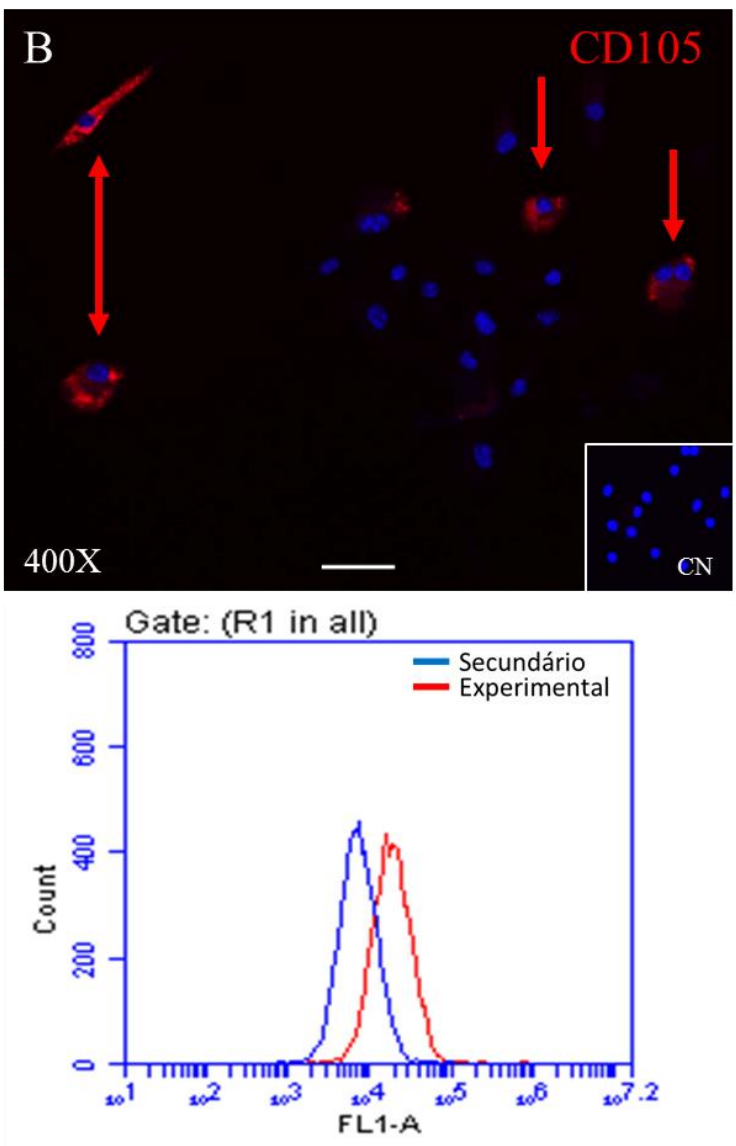

CD 105

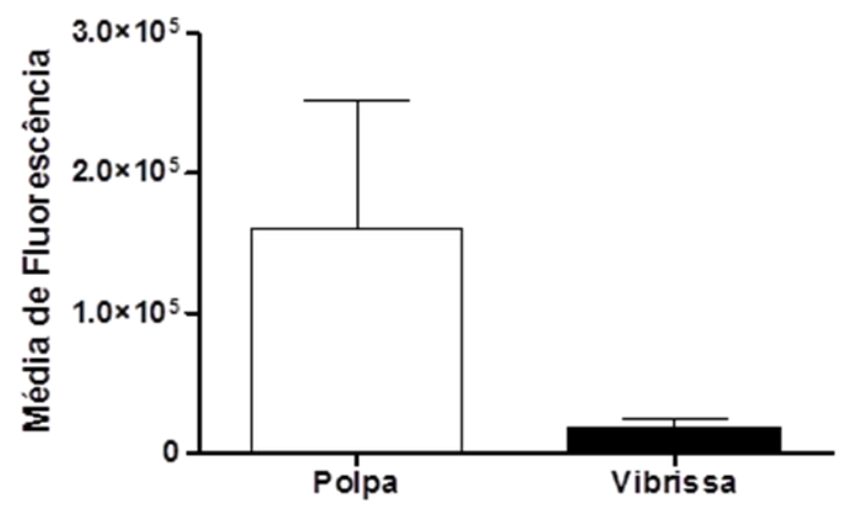

Figura 38 - Imunofluorescência e citometria de fluxo para CD105. Em (A) células de polpa dentária positivas para CD105 (setas verdes), logo abaixo citometria de fluxo de células isoladas de polpa dentária demostrando presença de células $\mathrm{CD}_{105^{+}}$. Em (B) célula de vibrissa positiva para CD105 (setas vermelhas), logo abaixo citometria de fluxo de células isoladas de vibrissas demostrando presença de células $\mathrm{CD}_{105^{+}}$. CN corresponde ao controle negativo de cada reação. Gráfico de barras mostra a média de fluorescência entre as duas culturas (polpa dentária e vibrissas) calculada pelo teste $\mathrm{t}$ de Student. Barras: (A e B) $20 \mu \mathrm{m}$. 

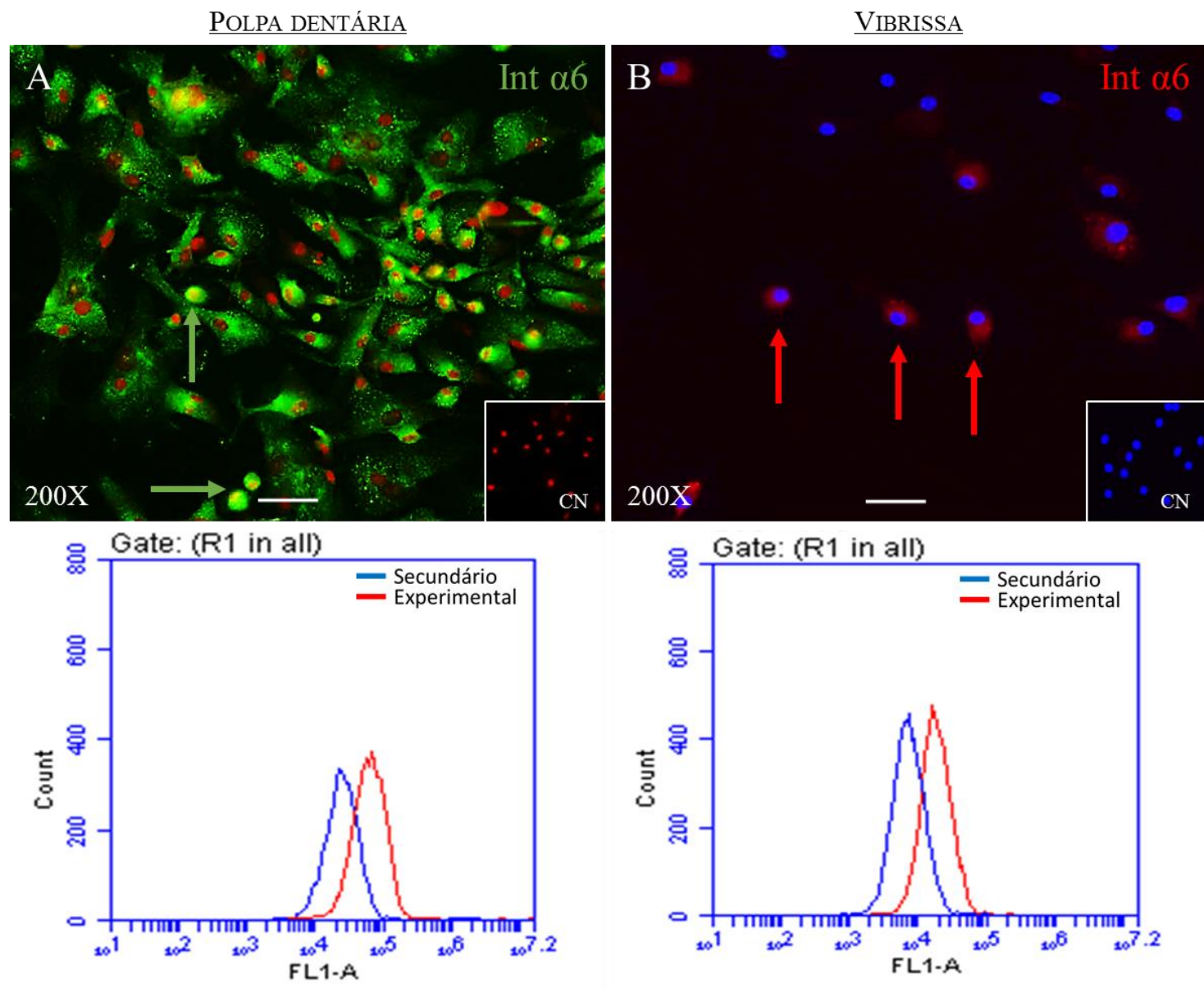

\section{Intregrina $\alpha 6$}

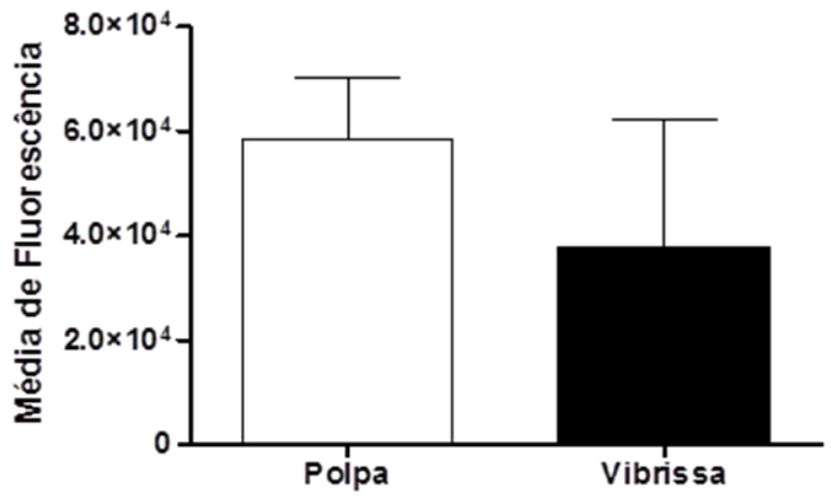

Figura 39 - Imunofluorescência e citometria de fluxo para Integrina $\alpha 6$. Em (A) células de polpa dentária positivas para Integrina $\alpha 6$ (setas verdes), logo abaixo citometria de fluxo de células isoladas de polpa dentária demostrando presença de células Integrina $\alpha 6^{+}$. Em (B) célula de vibrissa positiva para Integrina $\alpha 6$ (setas vermelhas), logo abaixo citometria de fluxo de células isoladas de vibrissas demostrando presença de células Integrina $\alpha 6^{+}$. CN corresponde ao controle negativo de cada reação. Gráfico de barras mostra a média de fluorescência entre as duas culturas (polpa dentária e vibrissas) calculada pelo teste t de Student. Barras: (A e B) $50 \mu \mathrm{m}$. 

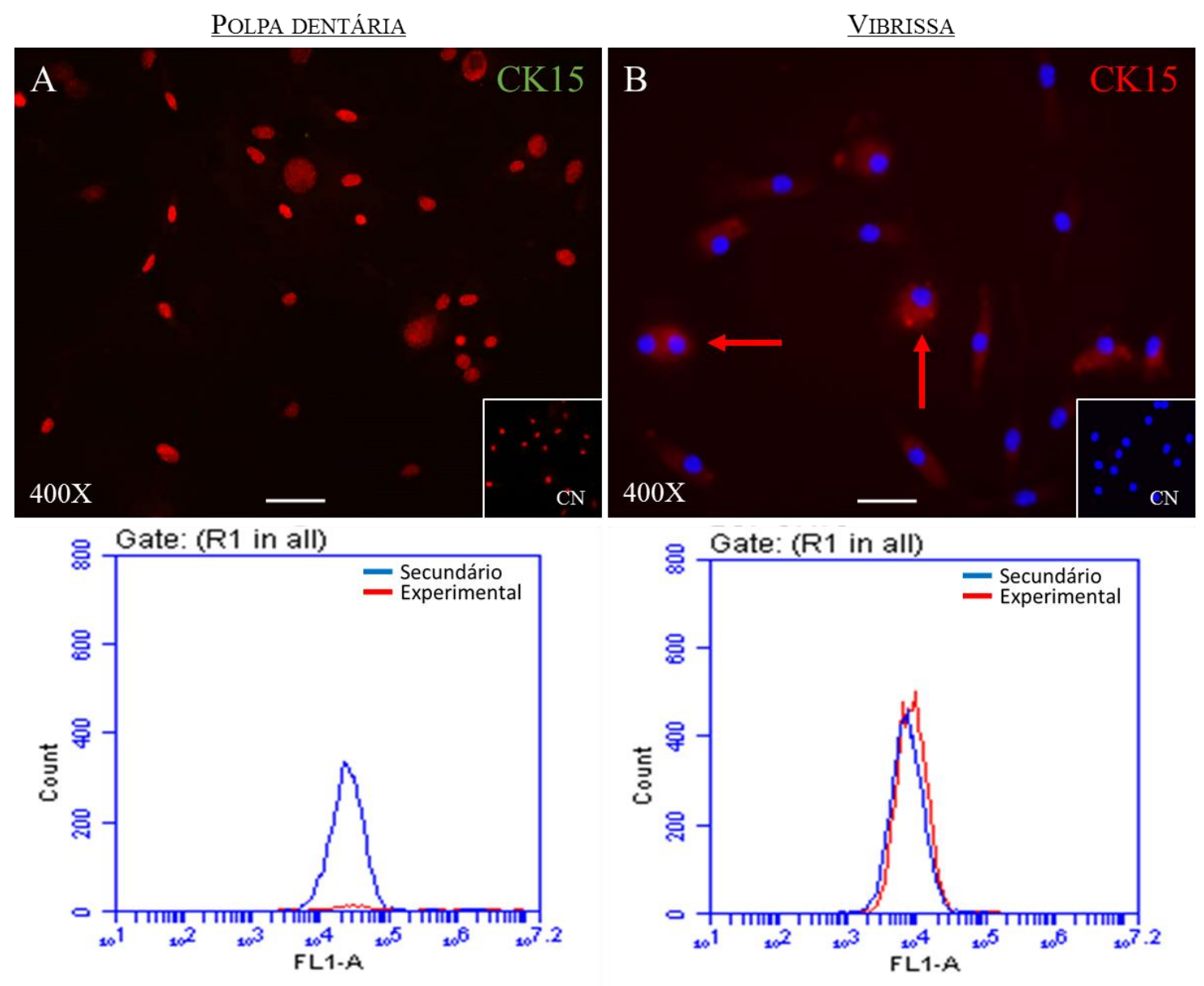

CK 15

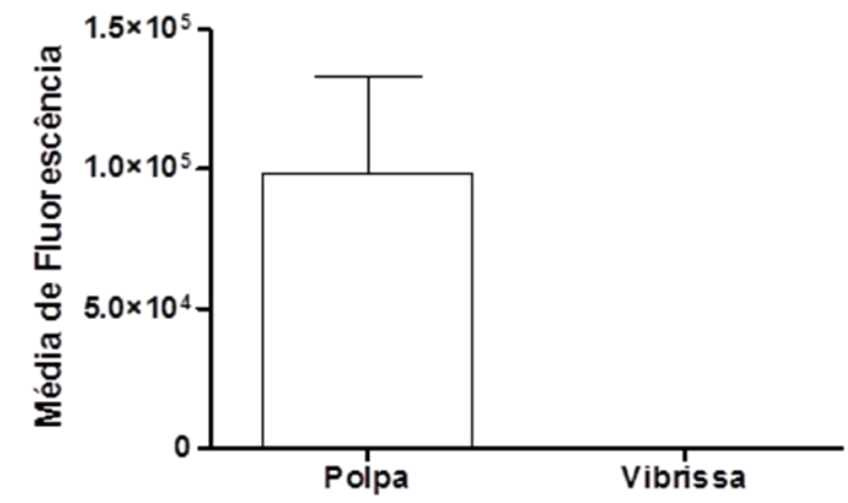

Figura 40 - Imunofluorescência e citometria de fluxo para Citoqueratina 15. Em (A) células de polpa dentária negativas para Citoqueratina 15, logo abaixo citometria de fluxo de células isoladas de polpa dentária demostrando ausência de células Citoqueratina $15^{+}$. Em (B) célula de vibrissa positiva para Citoqueratina 15 (setas vermelhas), logo abaixo citometria de fluxo de células isoladas de vibrissas demostrando presença de células Citoqueratina $15^{+}$. CN corresponde ao controle negativo de cada reação. Gráfico de barras mostra a média de fluorescência entre as duas culturas (polpa dentária e vibrissas) calculada pelo teste t de Student. Barras: (A e B) $50 \mu \mathrm{m}$. 
POLPA DENTÁRIA
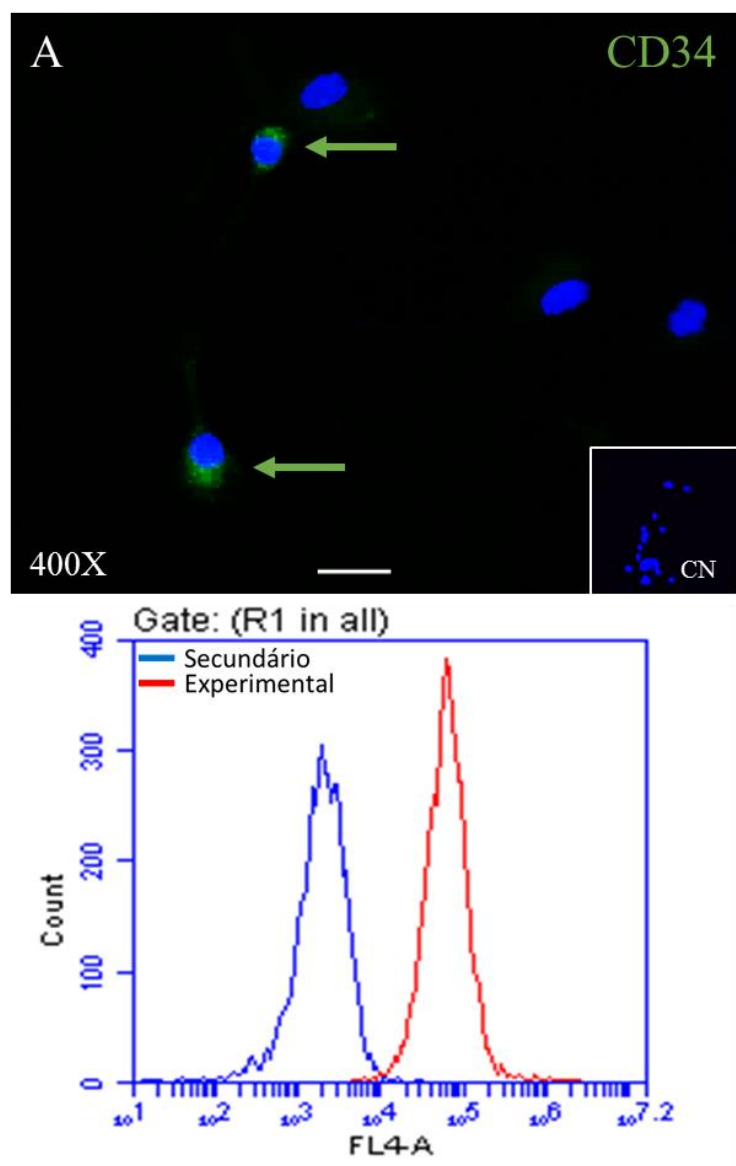

VIBRISSA


\section{34}

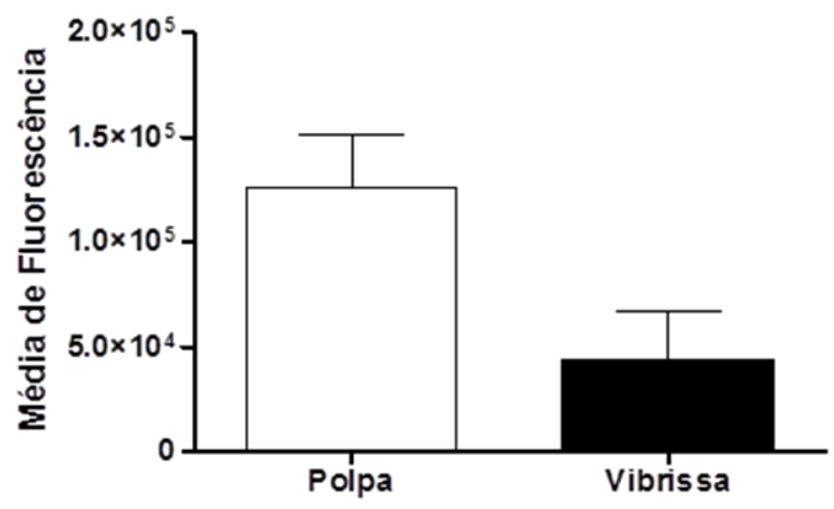

Figura 41 - Imunofluorescência e citometria de fluxo para CD34. Em (A) células de polpa dentária positivas para CD34 (setas verdes), logo abaixo citometria de fluxo de células isoladas de polpa dentária demostrando presença de células CD34 ${ }^{+}$. Em (B) célula de vibrissa positiva para CD34 (seta verde), logo abaixo citometria de fluxo de células isoladas de vibrissas demostrando presença de células $\mathrm{CD} 4^{+}$. CN corresponde ao controle negativo de cada reação. Gráfico de barras mostra a média de fluorescência entre as duas culturas (polpa dentária e vibrissas) calculada pelo teste t de Student. Barras: (A e B) $15 \mu \mathrm{m}$. 
POLPA DENTÁRIA
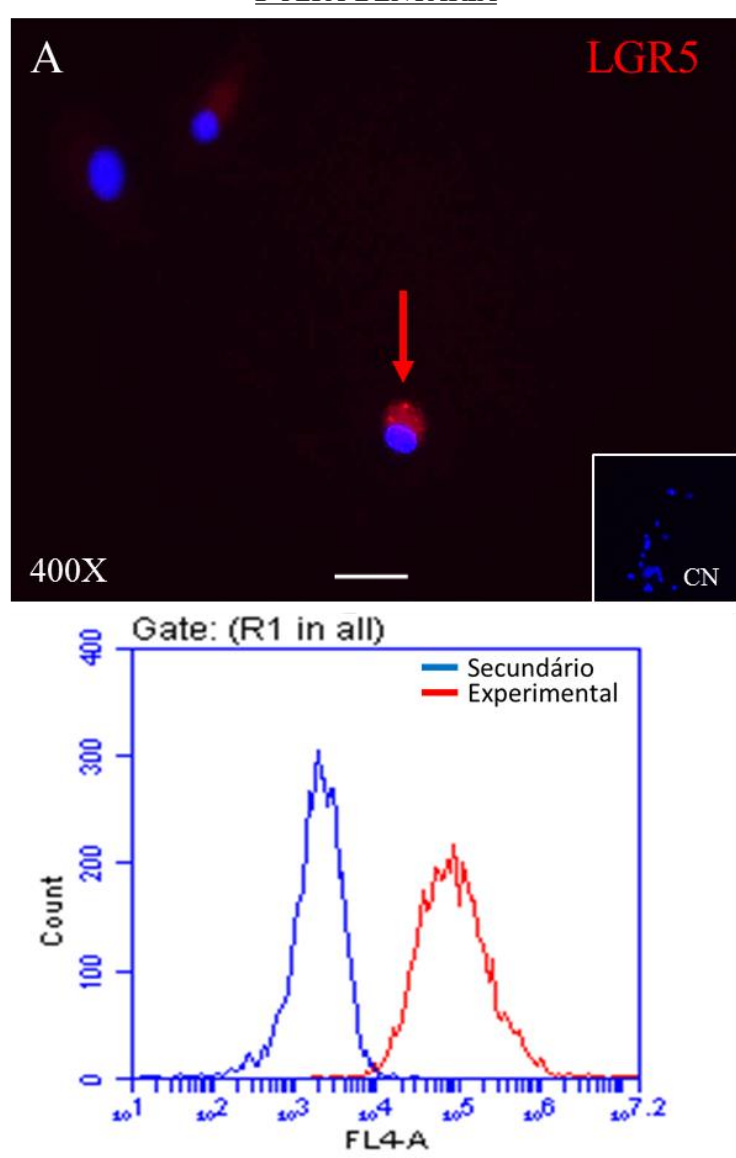

VIBRISSA


LGR 5



Figura 42 - Imunofluorescência e citometria de fluxo para LGR5. Em (A) célula de polpa dentária positiva para LGR5 (seta vermelha), logo abaixo citometria de fluxo de células isoladas de polpa dentária demostrando presença de células LGR5 ${ }^{+}$. Em (B) células de vibrissa positivas para LGR5 (seta verde), logo abaixo citometria de fluxo de células isoladas de vibrissas demostrando presença de células LGR5 ${ }^{+}$. CN corresponde ao controle negativo de cada reação. Gráfico de barras mostra a média de fluorescência entre as duas culturas (polpa dentária e vibrissas) calculada pelo teste $t$ de Student. Barras: (A) $15 \mu \mathrm{m}$, (B) $50 \mu \mathrm{m}$. 

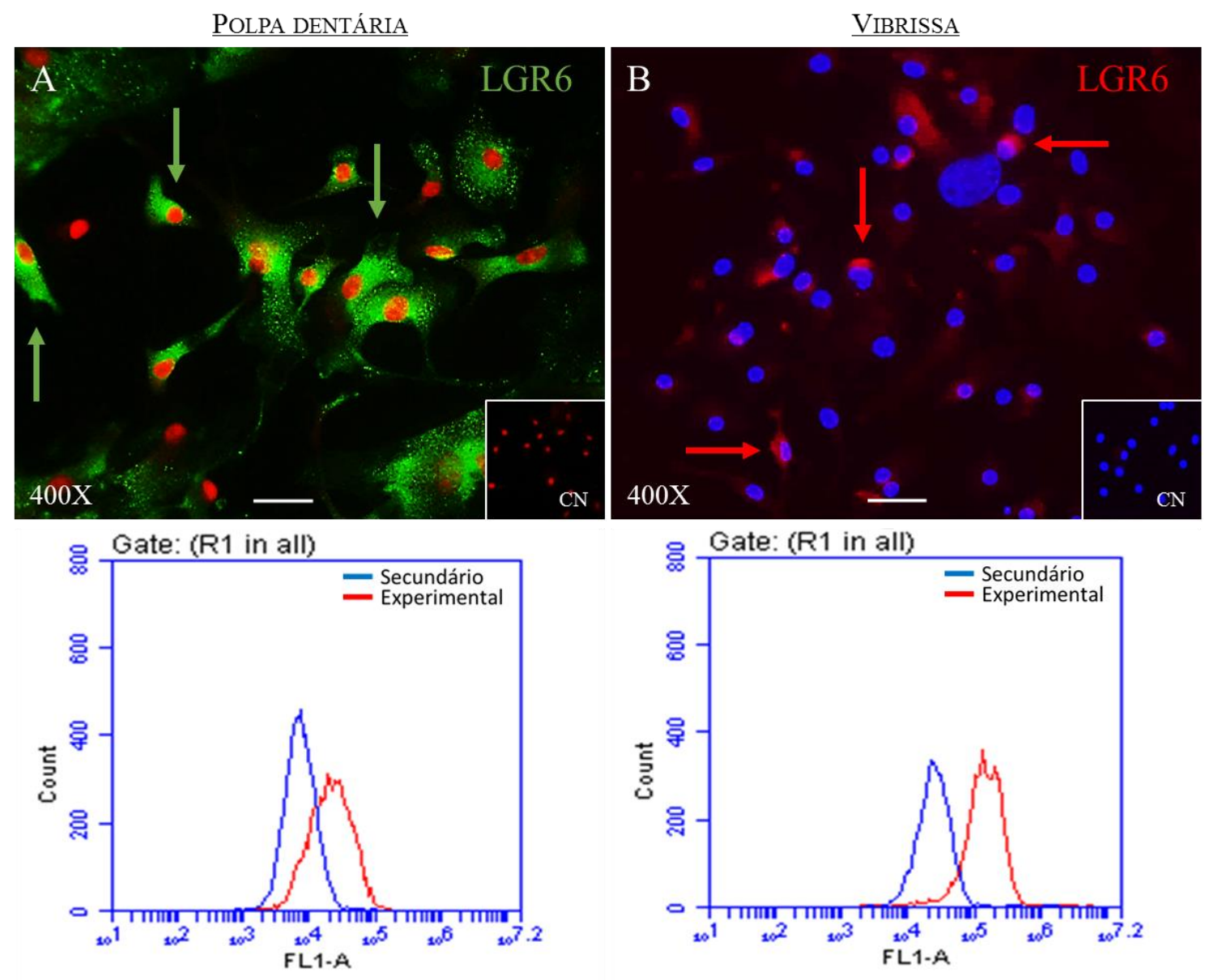

\section{LGR 6}

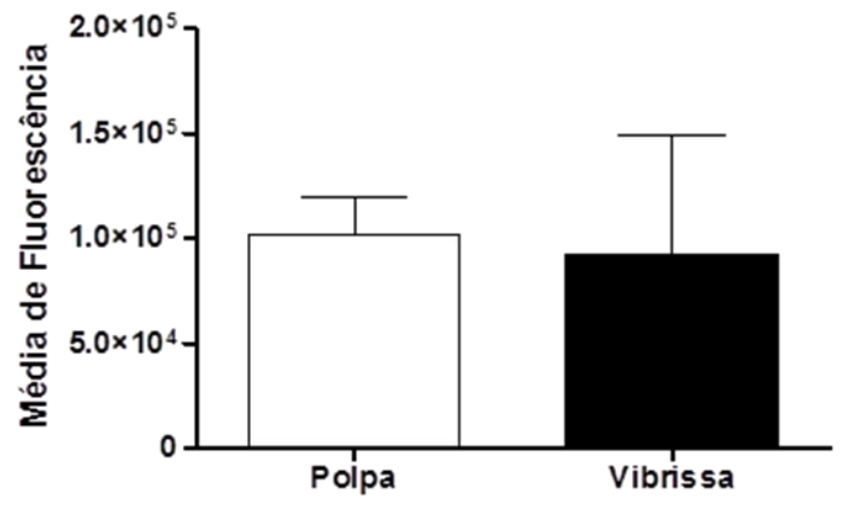

Figura 43 - Imunofluorescência e citometria de fluxo para LGR6. Em (A) células de polpa dentária positivas para LGR6 (setas verdes), logo abaixo citometria de fluxo de células isoladas de polpa dentária demostrando presença de células LGR6 ${ }^{+}$. Em (B) células de vibrissa positivas para LGR6 (setas vermelhas), logo abaixo citometria de fluxo de células isoladas de vibrissas demostrando presença de células LGR6 ${ }^{+}$. CN corresponde ao controle negativo de cada reação. Gráfico de barras mostra a média de fluorescência entre as duas culturas (polpa dentária e vibrissas) calculada pelo teste $\mathrm{t}$ de Student. Barras: (A e B) $15 \mu \mathrm{m}$. 
POLPA DENTÁRIA
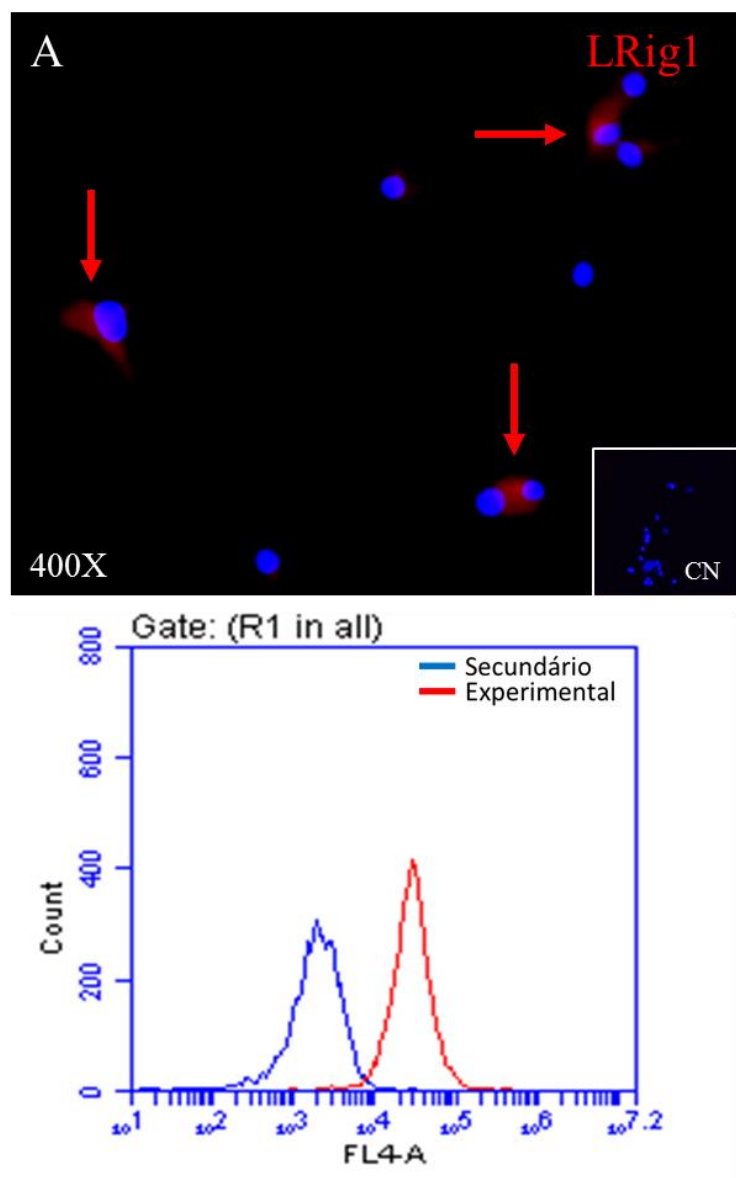

VIBRISSA
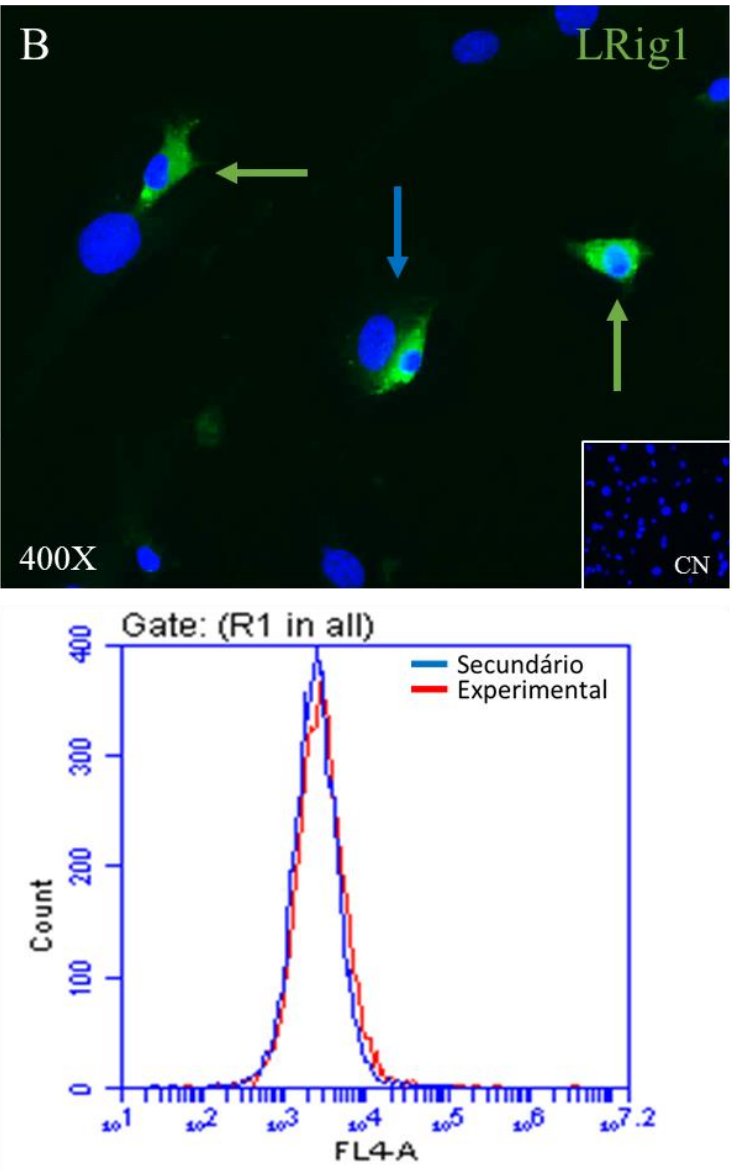

LRig1



Figura 44 - Imunofluorescência e citometria de fluxo para LRig1. Em (A) células de polpa dentária positivas para LRig1 (setas vermelhas), logo abaixo citometria de fluxo de células isoladas de polpa dentária demostrando presença de células LRig1+. Em (B) células de vibrissa positivas para LRig1 (setas verdes) e seta azul evidencia células em divisão assimétrica. Logo abaixo citometria de fluxo de células isoladas de vibrissas demostrando presença de células LRig1 ${ }^{+}$. CN corresponde ao controle negativo de cada reação. Gráfico de barras mostra a média de fluorescência entre as duas culturas (polpa dentária e vibrissas) calculada pelo teste t de Student. Barras: (A e B) $15 \mu \mathrm{m}$. 
POLPA DENTÁRIA

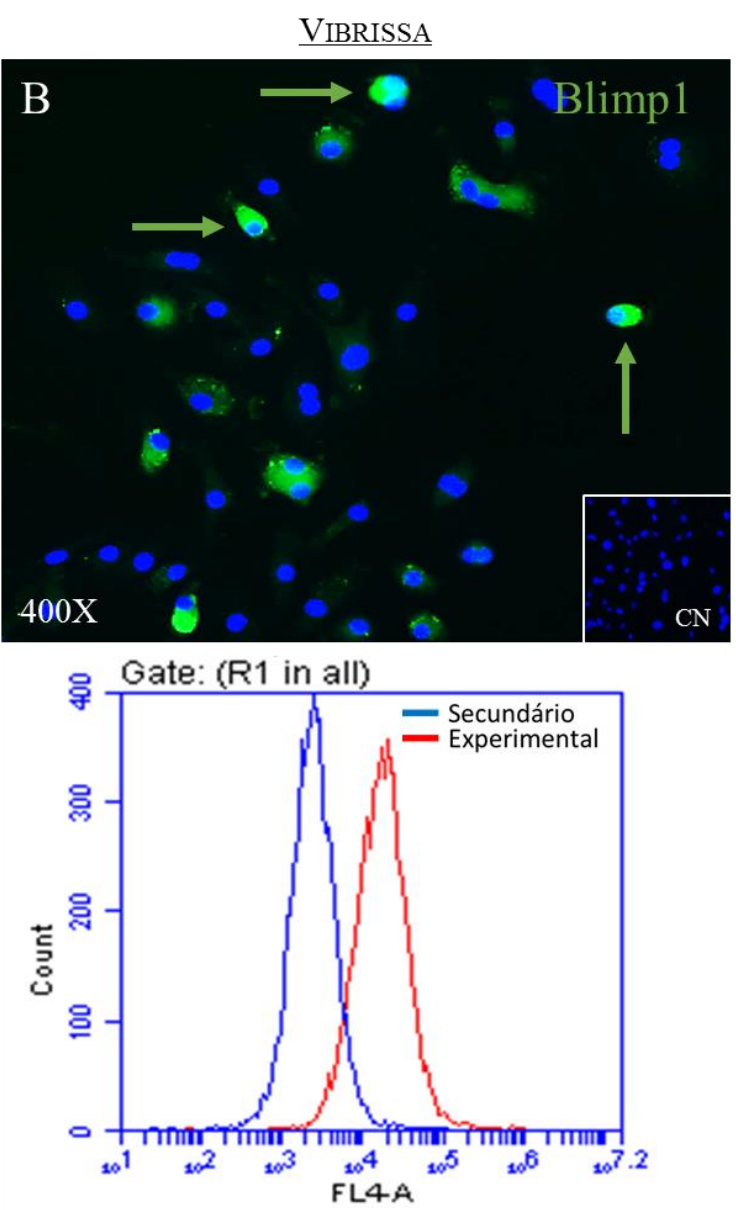

Blimp 1



Figura 45 - Imunofluorescência e citometria de fluxo para Blimp1. Em (A) células de polpa dentária positivas para LRig1 (setas vermelhas), logo abaixo citometria de fluxo de células isoladas de polpa dentária demostrando presença de células Blimp1 ${ }^{+}$. Em (B) células de vibrissa positivas para Blimp1 (setas verdes), logo abaixo citometria de fluxo de células isoladas de vibrissas demostrando presença de células Blimp1 $1^{+}$. CN corresponde ao controle negativo de cada reação. Gráfico de barras mostra a média de fluorescência entre as duas culturas (polpa dentária e vibrissas) calculada pelo teste $\mathrm{t}$ de Student. Barras: (A e B) $15 \mu \mathrm{m}$ 


\subsection{PCR}

Células isoladas da cultura de vibrissa e da cultura de polpa dentária foram utilizadas para o ensaio de PCR. Estas células foram cultivadas em meio DMEM - F12 e expandidas até alcançarem a semiconfluência de $70-80 \%$ na passagem T0P1 (vibrissa) e TOP2 (polpa dentária). Destas células foi extraído o RNA total que foi utilizado para a síntese do cDNA. A reação de PCR utilizou destes cDNA e de primers para os genes Sox2, Nanog e Oct4. Como controle foi utilizado cDNA extraído de células tronco embrionárias de camundongo e para controle da reação utilizamos a proteína gliceraldeído-3-fosfato desidrogenase (GAPDH).

É possível observar na figura 31 que todas as células [Células tronco embrionária (Eb), Células tronco de polpa dentária (Pp) e Células tronco de vibrissas (Vb)] apresentaram marcação do gene constitutivo GAPDH. As células tronco embrionárias apresentaram também presença dos genes Sox2, Nanog e Oct4. Células da polpa dentária e células das vibrissas apresentaram expressão de Sox 2 e Nanog, porém em diferentes intensidades onde as bandas de Sox2 e Nanog são mais intensas nas células das vibrissas do que nas células da polpa dentária. E é possível se notar uma ausência de Oct4 em ambos tipos celulares.

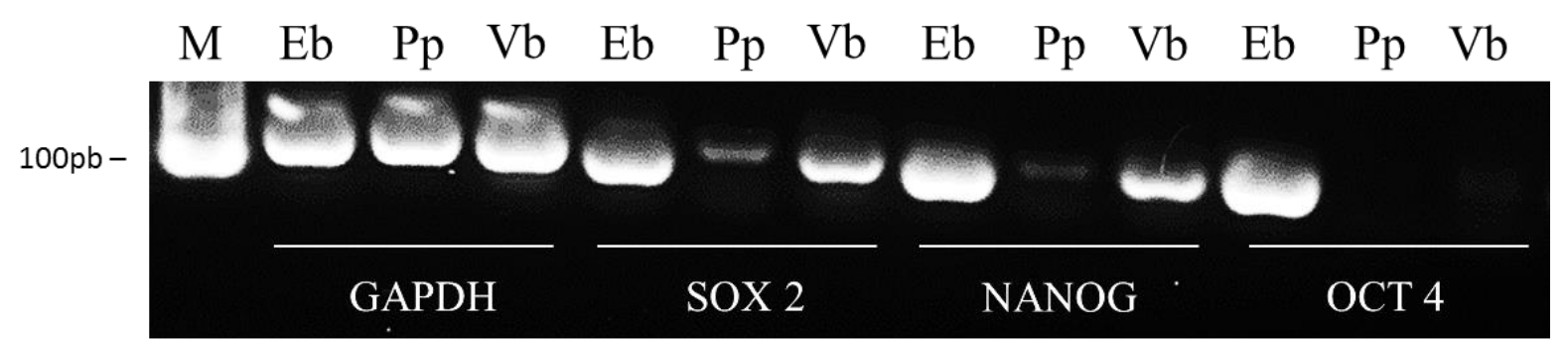

Figura 46 - Eletroforese em gel de agarose 1,2\% do cDNA a partir do lisado celular das culturas de vibrissa e polpa dentária. Foi analisada a expressão dos seguintes marcadores: GAPDH, Sox2, Nanog e Oct4. A coluna $\mathbf{M}$ representa o marcador (ladder) de 100 pb. (Eb) Célula tronco embrionária de camundongo. (Pp) Células tronco de polpa dentária. (Vb) Células tronco de vibrissas. 
Tabela 3 - Compilação dos resultados obtidos nas imunomarcações e PCR

\begin{tabular}{|c|c|c|c|c|c|c|c|c|c|}
\hline \multicolumn{5}{|c|}{ Polpa } & \multicolumn{5}{|c|}{ Vibrissa } \\
\hline $\begin{array}{l}\text { Técnica } \\
\text { Marcador }\end{array}$ & $\begin{array}{l}\text { IHQ } \\
\text { Tecido }\end{array}$ & $\begin{array}{c}\text { IF } \\
\text { Células }\end{array}$ & $\begin{array}{l}\text { FACS } \\
\text { Células }\end{array}$ & $\begin{array}{c}\text { PCR } \\
\text { Células }\end{array}$ & $\begin{array}{l}\text { Técnica } \\
\text { Marcador }\end{array}$ & $\begin{array}{l}\text { IHQ } \\
\text { Tecido }\end{array}$ & $\begin{array}{c}\text { IF } \\
\text { Células }\end{array}$ & $\begin{array}{l}\text { FACS } \\
\text { Células }\end{array}$ & $\begin{array}{c}\text { PCR } \\
\text { Células }\end{array}$ \\
\hline CKit & $\varnothing$ & $\checkmark$ & $\checkmark$ & -- & CKit & $\checkmark$ & $\checkmark$ & $\checkmark$ & - \\
\hline Nestina & $\checkmark$ & $\varnothing$ & $\emptyset$ & -- & Nestina & $\checkmark$ & $\checkmark$ & $\checkmark$ & -- \\
\hline Oct 4 & $\varnothing$ & $\varnothing$ & $\varnothing$ & $\varnothing$ & Oct4 & $\varnothing$ & $\checkmark$ & $\checkmark$ & $\varnothing$ \\
\hline Nanog & $\varnothing$ & $\checkmark$ & $\varnothing$ & $\checkmark$ & Nanog & $\varnothing$ & $\checkmark$ & $\checkmark$ & $\checkmark$ \\
\hline Sox 2 & $\varnothing$ & $\checkmark$ & $\varnothing$ & $\checkmark$ & Sox 2 & $\varnothing$ & $\checkmark$ & $\checkmark$ & $\checkmark$ \\
\hline $\mathrm{CD} 73$ & $\varnothing$ & $\checkmark$ & $\checkmark$ & - & CD73 & $\checkmark$ & $\checkmark$ & $\checkmark$ & -- \\
\hline $\mathrm{CD} 90$ & $\varnothing$ & $\checkmark$ & $\checkmark$ & -- & CD90 & $\varnothing$ & $\checkmark$ & $\checkmark$ & $\cdots$ \\
\hline CD105 & $\varnothing$ & $\checkmark$ & $\checkmark$ & -- & $\mathrm{CD} 105$ & $\checkmark$ & $\checkmark$ & $\checkmark$ & -- \\
\hline CK15 & $\varnothing$ & $\emptyset$ & $\emptyset$ & - & CK15 & $\checkmark$ & $\checkmark$ & $\checkmark$ & $\cdots$ \\
\hline Integrina $\alpha 6$ & $\checkmark$ & $\checkmark$ & $\checkmark$ & - & Integrina $\alpha 6$ & $\checkmark$ & $\checkmark$ & $\checkmark$ & - \\
\hline CD34 & $\emptyset$ & $\emptyset$ & $\checkmark$ & - & CD34 & $\checkmark$ & $\checkmark$ & $\checkmark$ & -- \\
\hline Blimp1 & $\varnothing$ & $\checkmark$ & $\checkmark$ & - & Blimp1 & $\checkmark$ & $\checkmark$ & $\checkmark$ & -- \\
\hline LGR5 & $\checkmark$ & $\checkmark$ & $\checkmark$ & - & LGR5 & $\checkmark$ & $\checkmark$ & $\checkmark$ & -- \\
\hline LGR6 & $\checkmark$ & $\checkmark$ & $\checkmark$ & - & LGR6 & $\checkmark$ & $\checkmark$ & $\checkmark$ & -- \\
\hline LRig1 & $\varnothing$ & $\checkmark$ & $\checkmark$ & -- & LRig1 & $\checkmark$ & $\checkmark$ & $\checkmark$ & -- \\
\hline
\end{tabular}


DISCUSSÃO 


\section{DISCUSSÃO}

Tecidos de dentes e vibrissas são duas fontes de células tronco adultas (HATZISTERGOS et al., 2015), ou seja, mantêm uma população de células indiferenciadas que persistem ao longo da vida. Ambos são originados com células da crista neural (HATZISTERGOS et al., 2015) e fornecem células que tem um grande potencial a serem utilizadas em medicina regenerativa (OTSU et al., 2014).

O presente trabalho realizou o estudo comparativo entre as células da cultura primária de vibrissas e da polpa dentária de camundongos C57BL6, que apesar de haver uma diferença na frequência das células imunopositivas para os marcadores estudados por citometria de fluxo e imunocitofluorescência, apresentou positividade para os marcadores mesmo estes resultados não sendo estatisticamente significantes. Desta forma, os resultados demonstram que as células da polpa dentária e vibrissa compartilham a mesma expressão de marcadores de células tronco pluripotente, neuronal, mesenquimal, epitelial e do folículo piloso.

A presença de células derivadas da crista neural em folículos pilosos já foi descrita na literatura (KREJCI; GRIM, 2010). Da mesma forma, a obtenção destas células a partir de cultura por digestão enzimática e por explante foliculares também já foi descrita e caracterizada em trabalhos anteriores (DREWA et al., 2009). Por ser um modelo já estabelecido e amplamente utilizado escolhemos a vibrissa como fonte de células tronco, assim adotamos estes dois métodos já estabelecidos para o isolamento de células tronco a partir da vibrissa (CTV), a fim de selecionar o melhor método quanto ao potencial de expansão, manutenção do estágio indiferenciado e morfologia celular.

De início, foram selecionados marcadores que são expressos nas vibrissas (BOEHNKE et al., 2012) e outros de interesse (AMOH et al., 2009; DOMINICI et al., 2006; THOMSOM et al., 2011) que foram testados ex vivo, em cortes histológicos de vibrissa e polpa dentária. A marcação de cada anticorpo ocorreu de forma específica nos folículos, marcando uma das diferentes camadas que o compõe, enquanto que na polpa dentária alguma região ou grupo de células mostraram imunomarcação positiva (figuras 13 - 25).

No que se refere ao cultivo, as culturas de vibrissas e polpa dentária foram inicialmente mantidas em DMEM F12, pois é o meio já utilizado para polpa dentária (KERKIS et al., 2006). Para efeito comparativo, as culturas de vibrissa foram testadas em 
quatro diferentes meios de cultura uma vez que Amoh et al, 2005, demonstrou que meios de cultura podem influenciar o cultivo. Os meios utilizados foram o DMEM F12, Low glucose, meio para cultivo de iPS e meio Neurobasal. Os dois primeiros meios apresentaram os melhores resultados uma vez que uma grande variedade de células pôde ser observada em ambos os meios. As células em meio DMEM tiveram um crescimento mais rápido em relação ao Low glucose. O meio iPS, por possuir fatores para manutenção de células embrionárias, possibilitou a formação de 'hair spheres', uma estrutura valiosa, pois demonstra a presença de células tronco (ZHOU; WANG; SUN, 2015). Na cultura mantida com meio neurobasal não foram encontradas células.

As vibrissas utilizadas nos experimentos foram extraídas dos camundongos C57BL6 e passaram por tratamento enzimático. Segundo Drewa et al., 2009, uma digestão enzimática feita com dispase ou colagenase $(1 \mathrm{mg} / \mathrm{mL})$ por 1 hora seria suficiente para promover a digestão dos tecidos externos à capsula e a própria. Porém, no presente trabalho não foi possível observar o isolamento robusto das células, então se optou pela não digestão das vibrissas, evitando assim um estresse extra nas culturas. Já os dentes tiveram as polpas dentárias removidas e colocadas diretamente em cultura seguindo o protocolo de Kerkis et al., 2006.

A identificação das células derivadas da crista neural é feita com a utilização de alguns marcadores como, por exemplo, o CKit e a Nestina (HATZISTERGOS et al., 2015; MII et al., 2013). Estes mesmos marcadores foram encontrados em ambas as culturas, como pode ser observado nas figuras 31 e 32. Com relação ao CKit, as células da cultura tanto de vibrissa como da polpa dentária tiveram um perfil semelhante (figura 31), o que já era esperado pelo fato de ambas compartilharem a mesma origem embrionária (PISPA; THESLEFF, 2003). Outros tipos celulares como células tronco hematopoiéticas, células tronco da medula óssea e progenitores de cardiomiócitos também expressam CKit (HATZISTERGOS et al., 2015; PISCIOTTA et al., 2015). Melanócitos também expressam CKit (JIANG et al., 2010; PISCIOTTA et al., 2015) e já foram obtidos por diferenciação de células tronco da polpa dentária (KAWASHIMA et al., 2012).

Nestina é um filamento intermediário próprio de células imaturas ou em rápida proliferação, e é também um marcador para células tronco que pode ser encontrado em folículos piloso e polpa dentária (KERKIS et al., 2012; VRAPCIU et al., 2014). Amoh et al, 2009 demonstrou que células $\mathrm{Nestina}^{+}$do folículo piloso podem ser diferenciadas em muitas linhagens quando estas são cultivadas em diferentes meios. Ele obteve células CD34 ${ }^{+}$ 
(cultivadas em DMEM F12) ou CK15 (cultivadas em RPMI suplementado com SFB), além de observar o aparecimento de células da linhagem neural (neurônios e glia), melanócitos e células do músculo liso. Gronthos et al., 2000 identificou uma população de células tronco com alta taxa de proliferação em polpa dentária humana e com capacidade de regenerar tecidos. Em 2003, Miura et al demonstraram que estas mesmas células expressam Nestina e apresentam também um potencial para derivar células neurais in vitro e in vivo (ELLIS et al., 2014). Nas culturas celulares isoladas de polpa dentária de camundongo realizadas neste trabalho, Nestina aparece em um número baixo de células enquanto que nas culturas de vibrissas este marcador é mais expresso (figura 32).

Para se identificar o estado indiferenciado das culturas de vibrissa e polpa dentária foi realizada imunomarcação nas culturas com anticorpos contra os fatores de transcrição Oct4, Nanog e Sox2 que são específicos para células tronco pluripotentes. O Oct4 é um membro pertencente à família POU5F1 e é expresso em células tronco embrionárias e germinativas. Os membros da família POU são proteínas de ligação ao DNA, ligando-se a uma região promotora ou reguladora de seus genes alvos e em seres humanos esta proteína é expressa até o estágio de blastocisto (LEE et al., 2006). A Oct4 também pode ser utilizada como um indutor de pluripotência como demonstrado por Grinnell et al., 2006, onde queratinócitos interfoliculares da epiderme basal expressaram marcadores específicos de CTE (Sox2 e Nanog) quando cultivados com meio condicionado com Oct4.

Nanog é outro fator de transcrição associado à manutenção das células pluripotentes da massa celular interna e a formação de células tronco embrionárias. Nanog é um fator inibidor de leucemia (LIF) e ativador do fator de transcrição-3-independente (STAT-3). Ele é regulado pela Oct4 e Sox2, e por sua vez, regula de forma positiva a expressão de Oct4, Sox2 e dele mesmo ligando-se a suas regiões de gene promotor (BOYER et al., 2005; LI, 2010; LOH; NG; NG, 2008). Em conjunto, estes três fatores de transcrição exercem um papel essencial na manutenção do estado de indiferenciação das células tronco, bloqueando genes que, na ausência dos transcritos, desencadeariam a diferenciação (BOYER et al., 2005). Sox2 é um fator de transcrição regulador expresso no início do desenvolvimento de muitos tecidos e está presente em CTE, na massa celular interna do embrião e em células germinativas primordiais (CARLIN et al., 2006), também é um cofator para Oct4 (GRINNELL et al., 2007), formando assim um complexo regulador de outros genes. Sox2 e Oct4 também são reguladores e indutores de pluripotência (BOSNALI et al., 2009). 
Como resultado das imunomarcações se observa uma leve diferença na expressão dos marcadores de pluripotência nas diferentes culturas. Nanog e Sox2 (figuras 34 e 35) tiveram valores maiores nas culturas de vibrissa enquanto que o Oct4 (figura 33) foi mais expresso nas culturas de polpa dentária. Por ser o primeiro fator de transcrição expresso pelas CT isso demonstra que as células da polpa dentária estão em um estágio mais primordial ou precursor do que as células de vibrissa. Outro fato que deve ser destacado é a expressão dos três fatores de transcrição nas células de polpa dentária o que indica sua capacidade de produzir teratomas, que é uma prova de seu potencial de célula pluripotente (KERKIS; CAPLAN, 2012). Os fatores de pluripotência também foram avaliados por PCR, onde observou-se que polpa dentária e vibrissa apresentam mRNAs dos fatores Nanog e Sox2, enquanto que Oct4 não é expresso.

A presença de células tronco mesênquimais também foi estudada nas culturas de vibrissas e polpa dentária. Um painel mínimo recomendado pela Sociedade Internacional para Terapia Celular composto por CD73, CD90 e CD105 foi utilizado (DOMINICI et al., 2006; ULLAH et al., 2015). A CD73 é uma proteína de membrana celular com ação enzimática responsável em transformar AMP em adenosina e fosfato, além de atuar na adesão celular regulando a interação da célula com alguns componentes da matriz celular como, por exemplo, a laminina e fibronectina (GAO; DONG; ZHANG, 2014). A CD90 é uma molécula de adesão presente na membrana celular de diferentes tipos celulares como as células tronco mesenquimais, hematopoiéticas e dos queratinócitos (NAKAMURA et al., 2006) e pode ser encontrada também em fibroblastos, neurônios e células endoteliais ativas (KISSELBAC et al., 2009). A CD105 (endoglina) é uma glicoproteína integral de membrana que é parte dos receptores para TGF $\beta$ e pode se associar também aos receptores para activina e proteína morfogenética óssea (BMP) (KAPUR; MORINE; LETARTE, 2013). Nos ensaios realizados, essa tríade de marcadores foi visualizada tanto nas culturas de polpa dentária e vibrissas (figuras 36 - 38). No ensaio imunohistoquímico CD73 e CD105 (figura 16 e 18) apresentaram marcações específicas na bainha externa das vibrissas, porém as vibrissas se mostraram negativas para CD90 (figura 17). É possível que as células da vibrissa, em resposta ao trauma do explante tenham aumentado a expressão de CD90 a fim de garantir a sua aderência nas placas de cultura o que facilitaria a sua detecção nos ensaios de imunofluorescência e citometria de fluxo. Esse tipo de comportamento foi observado por Deng et al., 2016, onde seu grupo realizou um teste no qual garrafas de cultura, contendo células tronco mesênquimais da medula óssea, foram agitadas em diferentes períodos e ao 
final, o grupo caracterizou as células e constatou um aumento na expressão da CD90 e integrina $\beta 1$, e uma diminuição em outros marcadores como CD45 e CD31, além de observar que células em suspensão não possuíam nenhuma marcação para CD90 ou integrina $\beta 1$.

Citoqueratina 15 (CK15) é um filamento intermediário tipo I expresso nos queratinócitos da camada basal dos epitélios (WASSEN et al., 1999) e no bulge de folículos (WATERS et al., 2007). Morris et al., 2004, demonstrou que queratinócitos $\mathrm{CK} 15^{+}$são multipotentes e contribuem de forma transiente na formação dos novos folículos, vibrissa, glândulas sebáceas e ainda podem fornecer células para epiderme em um eventual quadro de cicatrização ou regeneração. Interessantemente estas células são dispensáveis para a homeostasia da epiderme, pois contribuem fornecendo células para substituição de outras, mas não agem fisiologicamente na epiderme (ITO et al., 2007). Outra proteína também expressa em um grupo de células tronco da epiderme e em células tronco de folículos é a Integrina $\alpha 6$, onde em 1998, Li, Simmons e Kaur demonstraram que as mesmas são células quiescentes e exibem uma grande capacidade proliferativa. No ensaio imunohistoquímico realizado, CK15 e Integrina $\alpha 6$ marcaram a bainha externa dos folículos (figuras 18 e 19). $\mathrm{Na}$ figura 18 é possível observar também que a camada basal da epiderme se mostrou CK15 evidenciando assim uma similaridade entre estas células reforçando uma contribuição entre estes nichos. A presença destes dois marcadores também foi testada na polpa dentária e se observou que as células deste tecido se mostrou Integrina $\alpha 6^{+} / \mathrm{Ck} 15^{-}$(figuras 18 e 19). $\mathrm{Na}$ análise por citometria de fluxo e imunofluorescência das culturas de vibrissa se observa a presença de CK15, enquanto que nas culturas de polpa dentária CK15 encontra-se ausente (figura 40). A presença de Integrina $\alpha 6$ também foi avaliada nas culturas sendo ambas positivas tanto no método de imunofluorescência e citometria de fluxo onde, pela média de fluorescência, polpa teve uma maior expressão para este marcador (figura 39).

O último grupo de marcadores avaliados nas culturas de polpa dentária e vibrissa foram os marcadores para os diferentes grupos de células tronco presente nas vibrissas. $\mathrm{O}$ primeiro marcador é a glicoproteína CD34 que é expressa nas células progenitoras hematopoiética, músculo esquelético, trato gastrointestinal e células endoteliais (TREMPUS et al., 2003). Em camundongos as células do bulge também expressam esta glicoproteína além de poder apresentar concomitantemente positividade para CK15 e Int $\alpha 6$ (TREMPUS et al., 2003), porém em humanos a CD34 não é vista no bulge (COTSARELIS et al., 2006), mas sim na bainha externa dos folículos (DETERDING et al., 2011). Estas células possuem um grande leque de diferenciações e podem ser induzidas em células da glia, neurônios, células do 
músculo liso e queratinócitos (HEIDARI et al., 2016). Nos cortes histológicos (figura 20) se observa uma pequena população de células $\mathrm{CD} 34^{+}$ao lado da bainha externa, dentro do sinu cavernoso das vibrissas e a polpa dentária não apresentou positividade para este marcador. As culturas também aparecem pouco marcadas no ensaio de imunofluorescência (figura 41). $\mathrm{Na}$ citometria de fluxo a presença da CD34 nas culturas é evidenciada mostrando que a polpa dentária possui uma maior expressão quando comparada com as vibrissas, o que é corroborado pela média de fluorescência realizada entre elas (figura 41).

A proteína G acoplada ao receptor 5 contendo repetições ricas em leucina (LGR5 - do inglês "Leucine-rich repeat-containing G-protein coupled receptor 5") é uma molécula presente nas membranas de CT de estômago, intestino e do bulge dos folículos (CARMON et al., 2012). Ela é alvo da via de sinalização Wnt que esta associada à proliferação celular e ainda pode se associar a receptores hormonais (BARKER; CLEVERS, 2010). Utilizando-se de um gene repórter LGR5-LacZ, Barker e Clevers 2010 demonstraram elegantemente a contribuição das células LGR5 ${ }^{+}$no ciclo de formação de novos folículos mostrando que estas migram do bulge para o bulbo e lá se diferenciam nas diferentes linhagens do folículo. Estudos recentes mostram que a LGR5 também é encontrada na polpa dentária humana (KIM et al., 2014) e no reticulo estrelado de camundongos (SUOMALAINEM; THESLEFF, 2010), porém em ambos os casos eles não são regulados pela via de sinalização Wnt (KIM et al., 2014; SUOMALAINEM; THESLEFF, 2010). Nos cortes histológicos é possível observar a presença destes marcadores em ambos os tecidos (figura 22) onde raras células foram marcadas na polpa dentária, e nas vibrissas temos positividade nas células da cutícula. No cultivo celular foi possível observar a LGR5 em ambas as culturas imunomarcadas com fluoróforos (vibrissa e polpa dentária) (figura 42) e esta marcação também esteve presente nos testes de citometria de fluxo. Interessantemente as culturas de polpa dentária apresentaram maior positividade para LGR5 do que as vibrissas (figura 42).

A proteína $\mathrm{G}$ acoplada ao receptor 6 contendo repetições ricas em leucina (LGR6 - do inglês "Leucine-rich repeat-containing G-protein coupled receptor 6") é uma molécula presente nas membranas de CT do bulge dos folículos, porém, diferentemente das células $\mathrm{LGR}^{+}$elas não são reguladas pela via de sinalização do Wnt (CARMON et al., 2012; LEHOCZKY; TABIN, 2015). Isso ocorre porque as células LGR6 $^{+}$do bulge agem como células repositórias para a glândula sebácea e esta última não tem suas células reguladas pela via Wnt (CARMON et al., 2012; LEHOCZKY; TABIN, 2015). Um pequeno grupo de células das glândulas sudoríparas e epiderme interfolicular também expressam LGR6 (LEHOCZKY; 
TABIN, 2015), com destaque para as da epiderme, pois estas são células que migram do bulge para a epiderme e lá podem se diferenciar em todas as linhagens da pele (BARKER; CLEVERS, 2010). Já no dente, temos expressão de LGR6 tanto nas células epiteliais quanto mesênquimais envolvidas na odontogênese com maiores expressões nos odontoblastos e ameloblastos (KAWASAKI et al., 2014). Nos cortes histológicos, as células LGR6 ${ }^{+}$aparecem na região do istmo dos folículos e esta marcação segue em direção à epiderme (figura 23). Na polpa dentária a positividade deste marcador ocorre especificamente nos odontoblastos imediatamente adjacentes à dentina e nos ameloblastos (figura 23). Nos ensaios de imunofluorescência e citometria de fluxo as células de ambas as culturas se mostraram LGR6 ${ }^{+}$ (figura 43) onde, pela média de fluorescência, apresentam um valor semelhante de expressão para este marcador.

A proteína transmembrana semelhante a imunoglobulinas 1 com domínios ricos em leucina (LRig1 - do inglês "Leucine-rich repeats and Ig-like domains 1 ") é encontrada em CT quiescentes do cólon, intestino delgado, epiderme interfolicular e bulge de folículos (ORDONEZ-MORAN; HUELSKEN, 2012). Da mesma forma que acontece com as células $\mathrm{LGR6}^{+}$, as LRig1+ podem migrar do istmo do bulge para epiderme interfolicular (figura 24B). Elas dão origem às glândulas sebáceas durante a morfogênese do folículo através de divisões assimétricas, onde as células diferenciadas expressam Scd1 e perdem sua capacidade proliferativa (FRANCES; NIEMANN, 2012) (figura 44B, seta azul). No intestino delgado e cólon as células tronco LRIG1 $^{+}$agem nas células da cripta controlando o tamanho e a proliferação destas (ORDONEZ-MORAN; HUELSKEN, 2012). Isso é possível, porque elas suprimem o receptor ErbB/EGFR (Epidermal Growth Factor Receptor) para EGF (Epidermal Growth Factor). Nos cortes histológicos realizados (figura 24) polpa dentária se mostrou negativa para LRig1. Já no corte sagital da pele do focinho é possível visualizar positividade para LRig1 nos folículos e epiderme interfolicular o que sugere uma continuidade e/ou contribuição destes nichos entre si. Nos ensaios de imunofluorescência e citometria de fluxo realizados (figura 44) se observou a presença de poucas células positivas para LRig1 nas culturas de vibrissas e polpa dentária.

A proteína 1 de indução à maturação de linfócitos $\mathrm{B}$ (Blimp1 - do inglês " $B$ lymphocyte-induced maturation protein-1") é uma repressora transcricional com dedos de zinco (do inglês “zinc-finger transcriptional repressor”), expressa em vários tecidos agindo na regulação do crescimento celular, diferenciação e sobrevivência das células (ROBERTSON et al., 2007). Ela pode ainda reprimir fatores de transcrição como o Pax5, 
Myc e Bcl6 (NISHIKAWA et al., 2010) e em folículos, células Blimp ${ }^{+}$agem na manutenção das células da glândula sebácea (KRETZSCHMAR et al., 2014). Nas imunomarcações realizadas em tecido parafinado (figura 25), polpa dentária se mostrou Blimp1- enquanto que células Blimp $1^{+}$foram vistas na bainha externa das vibrissas. Nas culturas mantidas dos dois tecidos é possível encontrar células Blimp1 ${ }^{+}$entre as células de polpa dentária e vibrissas (figura 45).

Quando comparados entre si os resultados dos ensaios de imunohistoquímica, imunofluorescência e citometria de fluxo apresentaram algumas diferenças na expressão dos marcadores dentro do próprio tecido (tabela 3). A primeira divergência observada é com relação ao tecido da polpa dentária que se mostrou negativo para a maioria dos marcadores testados. É provável que o processo de descalcificação do material possa ter destruído os epítopos (moléculas alvo) uma vez que este protocolo utiliza soluções cujo pH é muito baixo, o que explica a presença de positividade nas culturas, pois estas foram iniciadas com explantes dos tecidos, ou seja, material fresco cultivado diretamente em placas sem o tratamento prévio do mesmo com processos químicos e/ou enzimáticos.

Outro possível fator que pode ter influenciado a expressão de marcadores é a manipulação do material. Os tecidos ainda in vivo encontravam-se em homeostasia, ou seja, estavam sendo controlados por mecanismos de regulação inter-relacionados a fim de regular o seu ambiente interno, de modo a manter uma condição estável mediante múltiplos ajustes de equilíbrio dinâmico e no momento da extração um estresse foi causado desencadeando assim a ativação de diferentes vias de sinalização bem como a supressão de outras.

E por fim, as diferenças observadas neste trabalho em relação à expressão dos marcadores de células tronco podem existir devido as diferenças especificas entre espécies na expressão dos mesmos e entre os próprios espécimes. No estudo de folículos pilosos e polpa dentária é comum utilizarem como modelo experimental camundongos, ratos e/ou material humano os quais possuem suas próprias singularidades. Para o desenvolvimento deste trabalho foram utilizados três animais que forneceram material biológico (polpa dentária e vibrissas) para o estabelecimento de culturas primárias. Ambos tecidos são formados por uma população heterogênea de células em especial as vibrissas que são praticamente um microambiente localizado na epiderme. Além de serem populações distintas tem-se ainda a influência das diversas passagens pelas quais as células passaram fazendo com que de certa forma o padrão de expressão pudesse ser alterado para uma baixa ou alta expressão implicando diretamente nos desvios padrão das médias de fluorescência. 
CONCLUSÃO 


\section{CONCLUSÕES}

O presente trabalho realizou um rastreio primário da análise comparativa da expressão diferencial de um painel de marcadores de células pluripotentes, mesenquimais e neuroepiteliais utilizando como modelo as culturas primárias de células isoladas de vibrissa e polpa dentária de camundongo que demonstrou:

Caracterização ex vivo da expressão de marcadores imunofenotípicos pelo ensaio de imunohistoquímica para células tronco na polpa dentária e vibrissa demonstrou distribuição diferencial destes marcadores em diversos sítios anatômicos (nichos celulares).

$\checkmark$ O cultivo de vibrissas e polpa dentária pode ser realizado por explante, sem a necessidade de digestões enzimáticas e em ambos os casos é possível de se obter células tronco;

Vibrissas e polpa dentária podem ser cultivadas em meio DMEM F12.

$\checkmark$ Nas culturas de polpa dentária e vibrissa se obteve células com morfologia fibroblast-like, epithelial-like e neuronal-like;

Caracterização in vitro da expessão de marcadores imunofenotípicos para células tronco nas culturas primárias isoladas da polpa dentária e vibrissa demonstrou que ambas populações celulares expressam um espectro parecido de marcadores de células tronco, que corrobora com a origem embrionária comum destas células, porém em proporções diferentes.

Os resultados sugerem que as culturas primárias de polpa dentária de camundongo C57BL6 apresentam positividade mais ampla ao espectro dos marcadores estudados, com destaque na positividade para LRIG1 e Blimp1.

A PCR realizada demonstrou que as células das duas culturas possuíam o mesmo padrão de expressão, sendo Oct4 $/ \mathrm{Nanog}^{+} / \mathrm{Sox}^{+}$. 
REFERÊNCIAS 


\section{REFERÊNCIAS*}

AGHAJANI, F.; HOOSHMAND, T.; KHANMOHAMMADI, M.; KHANJANI, S.; EDALATKHAH, H.; ZARNANI, A. H.; KAZEMNEJAD, S. Comparative Immunophenotypic Characteristics, Proliferative Features, and Osteogenic Differentiation of Stem Cells Isolated from Human Permanent and Deciduous Teeth with Bone Marrow. Molecular Biotechnology, v. 58, n. 6, p. 415-427, 2016.

AMABILE, G.; MEISSNER, A. Induced pluripotent stem cells: current progress and potential for regenerative medicine. Trends in Molecular Medicine, v.15, n. 2, p. 59-68, 2009.

AMICI, A. W.; YAMATO, M.; OKANO, T.; KOBAYASHI, K. The multipotency of adult vibrissa follicle stem cells. Differentiation, v. 77, n. 3, p. 317-323, 2009.

AMOH, Y., LI, L.; KATSUOKA, K.; HOFFMAN, R. M. Multipotent hair follicle stem cells promote repair of spinal cord injury and recovery of walking function. Cell Cycle, v 7, n 12, p. $1865-1869,2008$.

AMOH, Y.; LI, L.; KATSUOKA, K.; HOFFMAN, R. M. Multipotent nestin-expressing hair follicle stem cells. Journal Dermatology, v. 36, n. 1, p. 1-9, 2009.

APEL, C.; FORLENZA, O. V.; DE PAULA, V. J. R.; TALIB, L. L.; DENECKE, B.; EDUARDO, C. P.; GATTAZ, W. F. The neuroprotective affect of dental pulp cells in models of Alzheimer's and Parkinson's disease. Journal of neural transmission, v. 116, n. 1, p. 71-78, 2009.

ATHANASSIOU-PAPAEFTHYMIOU, M.; PAPAGERAKIS, P.; PAPAGERAKIS, S. Isolation and Characterization of Human Adult Epithelial Stem Cells from the Periodontal Ligament. Journal of Dental Research, v. 94, n. 11, p. 1591-1600, 2015.

ASAHARA, T.; KALKA, C.; ISNER, J. M. Stem cell therapy and gene transfer for regeneration. Gene Therapy, v. 7, n. 6, p. 451-457, 2000.

BARKER, N.; CLEVERS, H. Leucine-rich repeat-containing G-protein-coupled receptors as markers of adult stem cells. Gastroenterology, v. 138, n. 5, p. 1681-1696, 2010.

BELTRÃO-BRAGA, P. C.; PIGNATARI, G. C.; MAIORKA, P. C.; LIZIER, N. F.; WENCESLAU, C. V.; MIGLINO, M. A.; MUOTRI, A. R.; KERKIS, I. Feeder-free derivation of induced pluripotent stem cells from human immature dental pulp stem cells. Cell Transplantation Journal, v. 20, n. 11, p. 1707-1719, 2011.

BLANPAIN, C.; FUCHS, E. Epidermal homeostasis: a balancing act of stem cells in the skin. Nature Reviews. Molecular Cell Biology, v. 10, n. 3, p. 207-217, 2009.

\footnotetext{
*De acordo com: ASSOCIAÇÃO BRASILEIRA DE NORMAS TÉCNICAS. NBR6023: informações e documentação: referências: elaboração. Rio de Janeiro, 2002.
} 
BLAZEJEWSKA, E. A. M.; CALL, M. K.; YAMANAKA, O.; LIU, H.; SCHREHARDT, U. S.; KRUSE, F. E.; KAO, W. W. From hair to cornea: toward the therapeutic use of hair follicle-derived stem cells in the treatment of limbal stem cell deficiency. Stem cells, v. 29, n. 1, p. 57-66, 2011.

BOEHNKE, K.; FALKOWSKA-HANSEN, B.; STARK, H. J.; BOUKAMP, P. Stem cells of the human epidermis and their niche: composition and function in epidermal regeneration and carcinogenesis. Carcinogenesis, v. 33, n. 7, p. 1247-1258, 2012.

BOSNALI, M.; MÜNST, B.; THIER, M.; EDENHOFER, F. Deciphering the stem cell machinery as a basis for understanding the molecular mechanism underlying reprogramming. Cellular and Molecular Life Sciences, v. 66, n. 21, p. 3403-3420, 2009.

BOYER, L. A.; LEE, T. I.; COLE, M. F.; JOHNSTONE, S. E.; LEVINE, S. S.; ZUCKER, J. P. Core transcriptional regulatory circuitry in human embrionyc stem cells. Cell, v. 122, n. 6, p. 947-956, 2005.

BUENO, D. F.; KERKIS, I.; COSTA A. M.; MARTINS, M. T.; KOBAYASHI G. S.; ZUCCONI E.; FANGANIELLO R. D.; SALLES, F. T.; ALMEIDA A. B.; DO AMARAL, C. E.; ALONSO, N.; PASSOS-BUENO, M. R. New source of muscle-derived stem cells with potential for alveolar bone reconstruction in clef lip and/or palate patients. Tissue Engineering Part A, v. 15, n. 2, p. 427-435, 2009.

BLUM, H. S.; GRIM, M.; HU, Y. F.; SZEDER, V. Pluripotent neural crest stem cells in the adult hair follicle. Developmental dynamics, v. 231, n. 2, p. 258-269, 2004.

CARLIN, R.; DAVIS, D.; WEISS, M.; SCHULTZ, B.; TROYER, D. Expression of early transcription factors Oct-4, Sox-2 and Nanog by porcine umbilical cord (PUC) matrix cells. Reproductive Biology Endocrinology, v. 4, n. 8, p. 1-13, 2006.

CARMON, K. S.; LIN, Q.; GONG, X.; THOMAS, A.; LIU, Q. LGR5 interacts and cointernalizes with Wnt receptors to modulate Wnt/ $\beta$-catenin signaling. Molecular and Cellular Biology, v. 32, n. 11, p. 2054-2064, 2012.

CHENG, P. H.; SNYDER, B.; FILLOS, D.; IBEGBU, C. C.; HUANG, A. H.; CHAN, A. W. Postnatal stem/progenitor cells derived from the dental pulp of adult chimpanzee. BMC Cell Biology, v. 9, n. 20. P. 1-11, 2008.

CLARKE, M. F.; BECKER, M. W. Câncer: o lado maligno das células tronco. Scientific American Brasil, v. 51, n. 8, p. 39-46, 2006.

COTSARELIS, G. Epithelial stem cells: a folliculocentric view. Journal of Investigative Dermatology, v. 126, n. 7, p. 1459-1468, 2006.

COTSARELIS, G.; SUN, T. T.; LAVKER, R. M. Labels-retaining cells reside in the bulge area of pilosebaceous unit: implications for follicular stem cells, hair cycle, and skin carcinogenesis. Cell, v. 61, n. 7, p. 1329-1337, 1990. 
DELCARPIO, J. B.; CLAYCOMB, W. C. Cardiomyocyte transfer into the mammalian heart. Cell - to - cell interactions in vivo and in vitro. Annals of the New York Academy of Sciences, v. 752, p. 267-285, 1995.

DENG, G.; WANG, W.; YANG, C.; GAO, R.; YANG, X.; YE, X. Shaking improves the whole bone marrow adherent method of purification. Molecular Medicine Reports, v. 13, n. 4, p. 3133-3138, 2016

DETERDING, L. J.; WILLIAMS, J. G.; HUMBLE, M. M.; PETROVICH, R. M.; WEI, S. J.; TREMPUS, C. S.; GATES, M. B.; ZHU, F.; SMART, R. C.; TENNANT, R. W.; TOMER, K. B. CD34 Antigen: Determination of Specific Sites of Phosphorylation In Vitro and In Vivo. International Journal of Mass Spectrometry, v. 301, n. 1-3, p. 12-21, 2011.

DOMINICI, M.; LE BLANC， K.; MUELLER， I.; SLAPER-CORTENBACH， I.; MARINI, F.; KRAUSE, D.; DEANS, R.; KEATING, A.; PROCKOP, DJ.; HORWITZ, E. Minimal criteria for defining multipotent mesenchymal stromal cells. The International Society for Cellular Therapy Position Statement Cytotherapy, v. 8, n. 4, p. 315-317, 2006.

DÖRFL, J. The musculature of the mystacial vibrissae of the white mouse. Journal of Anatomy, v. 135, n. 1, p. 147-154, 1982.

DREWA, T.; JOACHIMIAK, R.; KAZNICA, A.; SARAFIAN, V.; SIR, J. Primary cultures from rat vibrissae as a potential cell source for in vitro construction of urinary bladder wall grafts. Transplantation Proceedings, v. 41, n. 5, p. 1932-1935, 2009.

DRISKELL, R. R.; GIANGRECO, A.; JENSEN, K. B.; MULDER, K. W.; WATT, F. M. Sox2-positive dermal papilla cells specify hair follicle type in mammalian epidermis. Development, v. 136, n. 16, p. 2815-2823, 2009.

EBERT, A. D.; YU, J.; ROSE JR, F. F.; MATTIS, V. B.; LORSON, C. V.; THOMSON, J. A.; SVENDSEN, C. V. Induced pluripotent stem cells from spinal muscular atrophy patient. Nature, v. 457, n. 7227, p. 277-280, 2009.

ELLIS, K. M.; O'CARROLL, D. C.; LEWIS, M. D.; RYCHKOV, G. Y.; KOBLAR, S. A. Neurogenic potential of dental pulp stem cells isolated from murine incisors. Stem Cell Research \& Therapy, v. 5, n. 1, p. 1-13, 2014.

EVANS, M. J.; KAUFFMAN, M. H. Establishment in culture of pluripontential cells from mouse embryos. Nature, v. 292, n. 5819, p. 154-156, 1998.

EVANS, M. J. Potential for genetic manipulation of mammalian. Molecular Biology \& Medicine, v. 6, n. 6, p. 557-565, 1989.

FODOR, W. L. Tissue engineering and cell based therapies, from the bench to the clinic: the potential to replace, repare and regenerate. Reproductive Biology and Endocrinology, v. 1, n. 102, p. 1-6, 2003. 
FONSECA, S. A. S.; ABDELMASSIH, A.; LAVAGNOLLI, T. M. C.; SERAFIM, R. C.; SANTOS, E. J.; MENDES, C.; AMBROSIO, C. E.; MIGLINO, M. A.; VISINTIN, J. A.; ABDELMASSIH, R.; KERKIS, I.; KERKIS, A. Human immature dental pulp stem cells (hIDPSC) contribution into developing mouse embryo: production of human/mouse pretermed chimeras. Cell Proliferation, v. 42, n. 2, p. 132-140, 2009.

FRANCES, D.; NIEMANN, C. Stem cell dynamics in sebaceous gland morphogenesis in mouse skin. Development Biology, v. 363, n. 1, p. 138-146, 2012.

GANDIA, C.; ARMIÑAN, A.; GARCÍA-VERDUGO, J. M.; LLEDÓ, E.; RUIZ, A.; MIÑANA, D.; SANCHEZ-TORRIJOS, J.; PAYÁ, R.; MIRABET, V.; CARBONELLUBEROS, F.; LLOP, M.; MONTERO, J. A.; SEPÚLVEDA, P. Human dental pulp stem cells improve left ventricular function, induce angiogenesis, and reduce infarct size in rats with acute myocardial infarction. Stem cell, v. 26, n. 3, p. 638-645, 2008.

GAO, Z. W.; DONG, K.; ZHANG, H. Z. The roles of CD73 in cancer. BioMed Research International, v. 2014, p. 1-9, 2014.

GOMES, J. A.; MONTEIRO, B. G.; MELO, G. B.; SMITH, R. H. CAVENAGHI PEREIRA DA SILVA, M.; LIZIER, N. F.; KERKIS, A.; CERRUTI, H.; KERKIS, I. Corneal reconstruction with tissue-engineered cell sheets composed of human immature dental pulp stem cells. Investigative Ophthalmology \&Visual Science, v. 51, n. 3, p. 1408-1414, 2010.

GRINNELL, K. L.; YANG, B.; ECKERT, R. L.; BICKENBACH, J. R. De-differentiation of mouse interfollicular keratinocytes by the embryonic transcription factor Oct-4. Journal Investigative Dermatology, v. 127, n. 2, p. 372-380, 2007.

GRAVES, K. H.; MOREADITH, R. W. Derivation and characterization of putative pluripotential embryonic stem cells from preimplantation rabbit embryos. Molecular Reproduction and Development, v. 36, n. 4, p. 434-433, 1993.

GRONTHOS, S.; BRAHIM, J.; LI, W.; FISHER, L. W.; CHERMAN, N.; BOYDE, A.; DENBESTEN, P.; GEHRON ROBEY, P.; SHI, S. Stem cell properties of human dental pulp stem cells. Journal of dental research, v. 81, n. 8, p. 531-535, 2002.

GRONTHOS, S.; MANKANI, M.; BRAHIM, J.; ROBEY, P. G.; SHI, S. Postnatal human dental pulp stem cells (DPSCs) in vitro and in vivo. Proceedings of the National Academy of Sciences of United States of America, v. 97, n. 25, p. 13625-13630, 2000.

HABIF, T. P. Dermatologia clínica: guia colorido para diagnóstico e tratamento. 4 ed., Porto Alegre: Artmed, p. 848-851, 2005.

HARADA, H.; KETTUNEN, P.; JUNG, H. S.; MUSTONEN, T.; WANG, Y. A.; THESLEFF, I. Localization of putative stem cells in dental epithelium and their association with Notch and FGF signaling. Journal of cell biology, v. 147, n. 1, p. 105-120, 1999.

HATZISTERGOS, K. E.; TAKEUCHI, L. M.; SAUR, D.; SEIDLER, B.; DYMECKI, S. M.; MAI, J. J.; WHITE, I. A.; BALKAN, W.; KANASHIRO-TAKEUCHI, R. M.; SCHALLY, A. V.; HARE, J. M. CKit ${ }^{+}$cardiac progenitors of neural crest origin. Proceedings of the National Academy of Sciences of United States of America, v. 112, n. 42, p. 13051-13056, 2015. 
HEIDARI, F.; YARI, A.; RASOOLIJAZI, H.; SOLEIMANI, M.; DEHPOOR, A.; SAJEDI, N.; VEIJOUYE, S. J.; NOBAKHT, M. Bulge Hair Follicle Stem Cells Accelerate Cutaneous Wound Healing in Rats. Wounds, v. 28, n. 4, p. 132-141, 2016.

HOLLAND, J. S. Concepções conflitantes - Comentário sobre o artigo de Weiss - Células tronco: O poder de dividir. National Geographic, n. 52, Julho, 2005.

HUANGFU, D.; OSAFUNE, K.; MAEHR, R.; GUO, W.; EIJKELENBOOM, A.; CHEN, S.; MUHLESTEIN, W.; MELTON, D. A. Induction of pluripotent stem cells from primary human fibroblasts with only Oct-4 and Sox2. Nature Biotechnology, v. 26, p. 1269-1275, 2008.

ISHITIKIEV, N.; YAEGAKI，K.; CALENIC，B.; NAKAHARA，T.; ISHIKAWA， H.; MITIEV, V.; HAAPASALO, M. Deciduous and permanent dental pulp mesenchymal cells acquired hepatic morphologic and functional features in vitro. Journal of endodontics, v. 36, n. 3, p. 469-474, 2010.

ITO, M.; YANG, Z.; ANDL, T.; CUI, C.; KIM, N.; MILLAR, S. E.; COTSARELIS, G. Wntdependent de novo hair follicle regeneration in adult mouse skin after wounding. Nature, v. 447, n. 7142, p. 316-320, 2007.

JENSEN, J.; TVEDESØE, C.; RÖLFING, J. H.; FOLDAGER, C. B.; LYSDAHL, H.; KRAFT, D. C.; CHEN, M.; BAAS, J.; LE, D. Q.; BÜNGER, C. E. Dental pulp-derived stromal cells exhibit a higher osteogenic potency than bone marrow-derived stromal cells in vitro and in a porcine critical-size bone defect model. SICOT-J, v. 2, n. 16, p. 1-9, 2016.

JIANG, S.; ZHAO, L.; PURANDARE, B.; HANTASH, B. M. Differential expression. Of stem cell markers in human follicular bulge and interfolicular epidermal compartments. Histochemistry and cell biology, v. 133, n. 4, p. 455-465, 2010.

JIANG, Y.; JAHAGIRDAR, B. N.; REINHARDT, R. L. Pluripotency of mesenchymal stem cells derived from adult marrow. Nature, n. 418, n. 6893, p. 41-49, 2002.

JUNQUEIRA, L. C.; CARNEIRO, J. In: Histologia básica. 10. ed. Rio de Janeiro: Guanabara Koogan, 2008. Cap. 18, p. 359-370.

KAPUR, N. K.; MORINE, K. J.; LETARTE, M. Endoglin: a critical mediator of cardiovascular health. Vascular Health and Risk Management, v. 9, p. 195-206, 2013.

KAWASHIMA, N. Characterisation of dental pulp stem cells: a new horizon for tissue regeneration? Archives of Oral Biology, v. 57, p. 1439-1458, 2012.

KAWASAKI, M.; PORNTAVEETUS, T.; KAWASAKI, K.; OOMMEN, S.; OTSUKATANAKA, Y.; HISHINUMA, M.; NOMOTO, T.; MAEDA, T.; TAKUBO, K.; SUDA, T.; SHARPE, P. T.; OHAZAMA, A. R-spondins/Lgrs expression in tooth development. Development dynamics: an official publication of the American Association of Anatomists, v. 243, n. 6, p. 844-851, 2014.

KELLY, P. N.; DAKIC, A.; ADAMS, J. M.; NUTT, S. L.; STRASSER, A. Tumor growth need not be driven by rare cancer stem cells. Science, v. 317, n. 5836, p. 337, 2007. 
KERKIS, I.; CAPLAN, A. I. Stem cells in dental pulp of deciduous teeth. Tissue Engineering Part B Reviews, v. 18, n. 2. P. 129-138, 2012.

KERKIS, I.; AMBROSIO, C. E.; KERKIS, A.; MARTINS, D. S.; ZUCCONI, E.; FONSECA, S. A.; CABRAL, R. M.; MARANDUBA, C. M.; GAISD, T. P.; MORINI, A. C.; VIEIRA, N. M.; BROLIO, M. P.; SANT'ANNA, O. A.; MIGLINO, M. A.; ZATZ, M. Early transplantation of human immature dental pulp stem cells from baby teeth to golden retriever muscular dystrophy (GRMD) dogs: Local or systemic? Journal of Translational Medicine, v. 6, n. 35, p. 1-13, 2008.

KERKIS, I.; KERKIS, A.; DOZORTSEV, D.; STUKART-PARSONS, C. P.; MASSIRONI, S. M. G.; PEREIRA, L. V.; CAPLAN, A. I.; CERRUTI, H. F. Isolation and characterization of a population of immature dental pulp stem cells expressing OCT-4 and others embryonic stem cells markers. Cell, Tissues, Organs, v. 184, n. 3-4, p. 105-116, 2006.

KIM, J. H.; JEON, M.; SONG, J. S.; LEE, J. H.; CHOI, B, J.; JUNG, H. S.; MOON, S. J.; DENBESTEN, P. K.; KIM, S. O. Distinctive genetic activity pattern ofthe human dental pulp between deciduous and permanentteeth. PLoS One, v. 9, n. 7, p. 1-13, 2014.

KISSELBACH, L.; MERGES, M.; BOSSIE, A.; BOYD, A. CD90 Expression on human primary cells and elimination of contaminating fibroblasts from cell cultures. Cytotechnology, v. 59, n. 1, p. 31-44, 2009.

KLIMCZAK, A.; KOZLOWSKA, U. Mesenchymal Stromal Cells and Tissue-Specific Progenitor Cells: Their Role in Tissue Homeostasis. Stem Cell International, v. 2016, p. 1-11, 2016.

KOBAYASHI, K.; ROCHAT, A.; BARRANDON, Y. Segregation of keratinocyte colonyforming cells in the bulge of the rat vibrissa. Proceedings of the National Academy of Sciences of United States of America, v. 90, n. 15, p. 7391-7395, 1993.

KOH, G. Y.; SOONPAA, M. H.; KLUG, M. G.; FIELD, L. J. Longterm survival of AT - 1 cardiomyocyte grafts in syngeneic myocardium. American Journal of Physiology, v. 264, n. 5, p. 1727-1733, 1993.

KOH, G. Y.; SOONPAA, M. H.; KLUG, M. G.; PRIDE, H. P.; COOPER, B. J.; ZIPES, D. P.; FIELD, L. J. Stable fetal cardiomyocyte grafts in the hearts or dystrophic mice and dogs. The Journal of Clinical Investigation, v. 96, n. 4, p. 2034-2042, 1995.

KONAGAYA, S.; IWATA, H. Reproducible preparation of spheroids of pancreatic hormone positive cells from human iPS cells: An in vitro study. Biochimica et Biophysica Acta (BBA)General Subjects, n. 16, 2016.

KREJCI, E.; GRIM, M. Isolation and characterization of neural crest stem cells from adult human hair follicles. Folia Biologica, v. 56, n. 4, p. 149 - 157, 2010.

KRETZSCHMAR, K.; COTTLE, D. L.; DONATI, G.; CHIANG, M. F.; QUIST, S. R.; GOLLNICK, H. P.; NATSUGA, K.; LIN, K. I.; WATT, F. M. BLIMP1 is required for postnatal epidermal homeostasis but does not define a sebaceous gland progenitor under steady-state conditions. Stem Cell Reports, v. 3, n. 4. P. 620-633, 2014. 
LAGA, A. C.; LAI, C. Y.; ZHAN, Q.; HUANG, S. J.; VELAZQUEZ, E. F.; YANG, Q.; HSU, M. Y., MURPHY, G. F. Expression of the embryonic stem cell transcription factor SOX2 in human skin: relevance to melanocyte and merkel cell biology. The American Journal of Pathology, v. 176, n. 2, p. 903-913, 2010.

LAINO, G.; CARINCI, F.; GRAZIANO, A.; D’AQUINO, R.; LANZA, V.; DE ROSA, A.; GOMBOS, F.; CARUSO, F.; GUIDA, L.; RULLO, R.; MENDITTI, D.; PAPACCIO, G. In vitro boné production using stem cells derived from human dental pulp. The journal of craniofacial surgery, v. 17, n. 3, p. 511-515, 2006.

LAKO, M.; ARMSTRONG, L.; CAIRNS, P. M.; HARRIS, S.; HOLE, N.; JAHODA, C. A. B. Hair follicle dermal cells repopulate the mouse haematopoietic system. Journal of cell science, v. 115, n. 20, p. 3967-3974, 2002.

LASLETT, A. L.; FILIPZYK, A. A.; PERA, M. F. Characterization and culture of human embryonic stem cells. Trends in Cardiovascular Medicine, v. 13, n. 7, p. 295-301, 2003.

LEE, J.; KIM, H. K.; RHO, J. Y.; HAN, Y. M.; KIM, J. The human OCT-4 isoforms differ in their ability to confer self-renewal. The Journal of Biological Chemistry, v. 281, n. 44, p. 33554-33565, 2006.

LEHOCZKY, J. A.; TABIN, C. J. Lgr6 marks nail stem cells and is required for digit tip regeneration. Proceedings of the National Academy of Sciences of United States of America, v. 112, n. 43, p. 13249-13254, 2015.

LESKO, M. H.; DRISKELL, R. R.; KRETZSCHMAR, K.; GOLDIE, S. J.; WATT, F. M. Sox 2 modulates the function of two distinct cell lineages in mouse skin. Developmental Biology, v. 382, n. 1, p. 15-26, 2013.

LI, M.; LIU, J. Y.; WANG, S.; XU, H.; CUI, L.; LV, S.; XU, J.; LIU, S.; CHI, G.; LI, Y. Multipotent neural crest stem cell-like cells from rat vibrissa dermal papila induce neuronal differentiation of PC12 cells. BioMed Research International, v. 2014, p. 1-13, 2014.

LI, Y. Q. Master stem celltranscription factors and signaling regulation. Cell Reprogramming, v. 12, n. 1, p. 3-13, 2010.

LI, M.; ZHANG, D.; HOU, Y.; JIAO, L.; ZHENG, X.; WANG, W. H. Isolation and culture of embryonic stem cells from porcine blastocysts. Molecular Reproduction and Development, $\mathrm{v}$. 65, n. 4, p. 429-434, 2003.

LI, L.; MIGNONE, J.; YANG, M.; MATIC, M.; PENMAN, S.; ENIKOLOPOV, G.; HOFFMAN, R. M. Nestin expression in hair follicle sheath progenitor cells. Proceedings of the National Academy of Sciences of the United States of America, v. 100, n. 17, p. 99589961, 2003.

LI, A.; SIMMONS, P. J.; KAUR, P. Identification and isolation of candidate human keratinocyte stem cells based on cell surface phenotype. Proceedings of the National Academy of Sciences of United States of America, v. 95, n. 7, p. 3902-3907, 1998. 
LIU, Y.; LYLE, S.; YANG, Z.; COTSARELIS, G. Keratin 15 promoter targets putative epithelial stem cells in the hair follicle bulge. The Journal of Investigative Dermatology, v. 121, n. 5, p. 963-968, 2003.

LOH, Y. H.; NG, J. H., NG, H. H. Molecular framework underlying pluripotency. Cell Cycle, v. 7, n. 7, p. 885-891, 2008.

LYLE, S.; SOLOMIDOU, M. C.; LIU, Y.; ELDER, D. E.; ALBELDA, S.; COTSARELIS, G. The C8/144B monoclonal antibody recognizes cytokeratin 15 and defines the location of human hair follicle stem cells. Journal of cell science, v. 111, n. 21, p. 3179-3188, 1998.

MARSHALL, B. T.; INGRAHAM, C. A.; WU, X.; WASHENIK, K. Future horizons in hair restoration. Facial plastic surgery clinics of North America, v 21, n 3, p. 521 - 528, 2013.

MARTIN, G. R. Isolation of a pluripotent cell line from early mouse embryos cultured in medium conditioned by teratocarcinoma stem cells. Proceedings of the National Academy of Sciences of United States of America, v. 78, n. 12, p. 7634-7638, 1981.

MATSU-URA, T.; SASAKI, H.; OKADA, M.; MIKOSHIBA, K.; ASHRAF, M. Attenuation of teratoma formation by $\mathrm{p} 27$ overexpression in induced pluripotent stem cells. Stem Cell Research \& Therapy, v. 7, n. 30, p. 1-12, 2016.

MEAD, B.; LOGAN, A.; BERRY, M.; LEADBEATER, W.; SCHEVEN, B. A. Concise Review: Dental Pulp Stem Cells: A Novel Cell Therapy for Retinal and Central Nervous System Repair. Stem Cells, v 34, n 6, p. 1421 - 1426, 2016.

MENDONÇA COSTA, A.; BUENO, D. F.; MARTINS, M. T.; KERKIS, I.; KERKIS, A.; FANGANIELLO, R. D.; CERRUTI, H.; ALONSO, N.; PASSOS-BUENO, M. R. Reconstruction of large cranial defects in nonimmunosuppressed experimental design with human dental pulp stem cells. The Journal of Craniofacial Surgery, v. 19, n. 1, p. 204-210, 2008.

MII, S.; DUONG, J.; TOME, Y.; UCHUGONOVA, A.; LIU, F.; AMOH, Y.; SAITO, N.; KATSUOKA, K.; HOFFMAN, R. M. The role of hair follicle nestin-expressing stem cells during whisker sensory-nerve growth in long-term 3D culture. Journal of Cellular Biochemistry, v. 114, n. 7, 1674-1684, 2013.

MILETICH, I.; SHARPE, P.T. Neural crest contribution to mammalian tooth formation. Birth Defects Research Part C Embryo Today, v. 72, n. 2, p. 200-212, 2004.

MINGUELL, J. J.; CONGET, P.; ERICES, A. Biology and clinical utilization of mesenchymal progenitor cells. Brazilian Journal of Medical and Biology Research, v. 33, n. 8, p. 881-887, 2000.

MIURA, M.; GRONTHOS, S.; ZHAO, M.; LU, B.; FISHER, L. W.; ROBEY, P. G.; SHED: stem cells from human exfoliated deciduous teeth. Proceedings of the National Academy of Sciences of the United States of America, v. 100, n. 10, p. 5807-5812, 2003. 
MONTEIRO, B. G.; SERAFIM, R. C.; MELO, G. B.; SILVA, M. C.; LIZIER, N. F.; MARAMBUBA, C. M.; SMITH, R. L.; KERKIS, A.; CERRUTI, H.; GOMES, J. A.; KERKIS, I. Human immature dental pulp stem cells share key characteristic features with limbal stem cells. Cell Proliferation, v. 42, n. 5, p. 587-594, 2009.

MORRIS, R. J.; LIU, Y.; MARLES, L.; YANG, Z.; TREMPUS, C.; LI, S.; LIN, J. S.; SAWICKI, J. A. COTSARELIS G. Capturing and profiling adult hair follicle stem cells. Nature Biotechnology, v. 22, n. 4, p. 411-417, 2004.

MUOTRI, A. R.; MARCHETTO, M. C.; SUZUKI, M. F.; OKAZAKI, K.; LOTFI, C. F.; BRUMATTI, G.; AMARANTES - MENDES, G. P.; MENCK, C. F. Low amounts of the DNA repair XPA protein are sufficient to recover UV-resistance. Carcinogenesis, v. 23, n. 6, p. 1039-1046, 2002.

NAKAMURA, Y.; MUGURUMA, Y.; YAHATA ,T.; MIYATAKE, H.; SAKAI, D.; MOCHIDA, J.; HOTTA, T.; ANDO, K. Expression of CD90 on keratinocyte stem/progenitor cells. The British Journal of Dermatology, v. 154, n. 6, p. 1062-1070, 2006.

NIADA, S.; GIANNASI, C.; FERREIRA, L. M.; MILANI, A.; ARRIGONI, E.; BRINI, A. T. $17 \beta$-estradiol differently affects osteogenic differentiation of mesenchymal stem/stromal cells from adipose tissue and bone marrow. Differentiation, v. 91, n. 2, p. 1-7, 2016.

NISHIKAWA, K.; NAKASHIMA, T.; HAYASHI, M.; FUKUNAGA, T.; KATO, S.; KODAMA, T.; TAKAHASHI, S.; CALAME, K.; TAKAYANAGI, H. Blimp1-mediated repression of negative regulators is required for osteoclast differentiation. Proceedings of the National Academy of Sciences of United States of America, v. 107, n. 7, p. 3117-3122, 2010.

NISHINO, Y.; YAMADA, Y.; EBISAWA, K.; NAKAMURA, S.; OKABE, K.; UMEMURA, E.; HARA, K.; UEDA, M. Stem cells from human exfoliated deciduous teeth (SHED) enhance wound healing and the possibility of novel cell therapy. Cytotherapy, v 13, $\mathrm{n}$ 5 , p. $598-605,2011$.

ORDÓÑEZ-MORÁN, P.; HUELSKEN, J. Lrig1: a new master regulator of epithelial stem cells. The EMBO Journal, v. 31, n. 9, p. 2064-2066, 2012.

OSHIMA, H.; ROCHAT, A.; KEDZIA, C.; KOBAYASHI, K.; BARRANDON, Y. Morphogenesis and renewal of hair follicles from adult multipotent stem cells. Cell, v. 104, n. 2, p. 233-245, 2001.

OTSU, K.; KUMAKAMI-SAKANO, M.; FUJIWARA, N.; KIKUCHI, K.; KELLER, L.; LESOT, H.; HARADA, H. Stem cell sources for tooth regeneration: current status and future prospects. Frontiers in Physiology, v. 5, n. 36, p. 1-10, 2014.

PISCIOTTA, A.; CARNEVALE, G.; MELONI, S.; RICCIO, M.; DE BIASI, S. GIBELLINI, L.; FERRARI, A.; BRUZZESI, G.; DE POL, A. Human dental pulp stem cells (hDPSCs): isolation, enrichment and comparative differentiation of two sub-populations. BMC Developmental Biology, v. 15, n. 14, p. 1-16, 2015. 
PISPA, J.; THESLEFF, I. Mechanisms of ectodermal organogenesis. Developmental biology, v. 262, n. 2, p. 195-205, 2003.

PITTENGER, M. F.; MACKAY, A. M.; BECK, S. C.; JAISWAL, R. K.; DOUGLAS. R.; MOSCA, J. D.; MOORMAN, M. A.; SIMONETTI, D. W.; CRAIG, S.; MARSHAK, D. R. Multilineage potential of adult human mesenchymal stem cells. Science, v. 284, n. 5411, p. 143-147, 1999.

PLIKUS, M. V.; GAY, D. L.; TREFFEISEN, E.; WANG, A.; SUPAPANNACHART, R. J.; COTSARELIS, G. Epithelial stem cells and implications for wound repair. Seminars in Cell \& Developmental Biology, v. 23, n. 9, p. 946-953, 2012.

PLIKUS, M. V. At the dawn of hair research - testing the limits of hair follicle regeneration. Experimental Dermatology, v. 23, n. 5, p. 314-315, 2014.

POTTEN, C. S.; BOOTH, C. Keratinocyte stem cells: a commentary. Journal of Investigative Dermatology, v. 119, n. 4, p. 888-899, 2002.

POULSOM, R.; ALISON, M. R.; FORBES, S. J.; WRIGHT, N. A. Adult stem cells plasticity. The Journal of Pathology, v. 197, n. 4, p. 441-456, 2002.

REYNOLDS, A. J.; JAHODA, C. A. B. Cultured human and rat tooth papilla cells induce hair follicle regeneration and fiber growth. Differentiation, v. 72, n. 9-10, p. 566-575, 2004.

REYNOLDS, A. J.; JAHODA, C. A. B. Hair follicle stem cells? A distinct germinative epidermal cell population is activated in vitro by the presence of hair dermal papilla cells. Journal of cell science, v. 99, n. 2, p. 373-385, 1991.

ROBERTSON, E. J.; CHARATSI, I.; JOYNER, C. J.; KOONCE, C. H.; MORGAN, M.; ISLAM, A.; PATERSON, C.; LEJSEK, E.; ARNOLD, S. J.; KALLIES, A.; NUTT, S. L.; BIKOFF, E. K. Blimp1 regulates development of the posterior forelimb, caudal pharyngeal arches, heart and sensory vibrissae in mice. Development, v. 134, n. 24, p. 4335-4345, 2007.

ROCHAT, A.; KOBAYASHI, K.; BARRANDON, Y. Location of stem cells of human hair follicles by clonal analysis. Cell, v. 76, n. 6, p. 1063-1073, 1994.

ROELL, W.; LU, Z. J.; BLOCH, W.; SIEDNER, S.; TIEMAMM, K.; XIA, Y.; STOECKER, E.; FLEISCHMANN, M.; BOHLEN, H.; STEHLE, R.; KOLOSSOV, E.; BREM, G.; ADDICKS, K.; PFIPZER, G.; WELZ, A.; HESCHELER, J.; FLEISCHMANN, B. K. Cellular cardiomyoplasty improves survival after myocardial injury. Circulation, v. 105, n. 20, p. 2435-2441, 2002.

SACHINIDIS, A.; GISSEL, C.; NIERHOFF, D.; HIPPLER - ALTENBURG, R.; SAUER, H.; WARTENBERG, M.; HESTHELER, J. Identification of plateled - derived growth factor - BB as cardiogenesis - inducing factor in mouse embryonic stem cells under serum - free conditions. Cellular physiology and biochemistry: international journal of experimental cellular physiology, biochemistry, and pharmacology, v. 13, n. 6, p. 423-429, 2003.

SIEBER-BLUM, M.; GRIM, M.; HU, Y. F.; SZEDER, V. Pluripotent neural crest stem cells in the adult hair follicle. Developmental dynamics, v. 231, n. 2, p. 258-269, 2004. 
SLACK, J. M. W. Stem cells in epithelial tissues. Science, v. 287, n. 5457, p. 1431-1433, 2000.

STENN, K. S.; PAUS, R. Controls of hair follicle cycling. Physiological Reviews, v. 81, n. 1, 449-494, 2001.

SUOMALAINEN, M.; THESLEFF, I. Patterns of Wnt pathway activity in the mouse incisor indicate absence of Wnt/beta-catenin signaling in the epithelial stem cells. Developmental dynamics: an official publication of the American Association of Anatomists, v. 239, n. 1, p. 364-372, 2010.

TAKAHASHI, K.; YAMANAKA, S. Induction of pluripotent stem cells from mouse embryonic and adult fibroblast cultures by defined factors. Cell, v. 126, n. 4, p. 652-655, 2006.

TARNOWSKI, M.; SIERON, A. L. Adult stem cells and their ability to differentiate. Medical science monitor: international medical journal of experimental and clinical research, v. $12, \mathrm{n}$. 8, p. 154-163, 2006.

TATUllO, M.; MARRELlI, M.; SHAKESHEFF, K. M.; WHITE, L. J. Dental pulp stem cells: function, isolation and applications in regenerative medicine. Journal of tissue engineering and regenerative medicine, v. 9, n. 11, p. 1205-1216, 2015.

TAYLOR, G.; LEHRER, M. S.; JENSEN, P. J.; SUN, T. T.; LAVKER, R. M. Involvement of follicular stem cells in forming not only the follicle but also the epidermis. Cell, v. 102, n. 4, p. 451-461, 2000.

THOMSOM, J. A.; KALISHMAN, J.; GOLOS, T. G.; DURNING, M.; HARRIS, C. P.; BECKER, R. A.; HEARM, J. P. Isolation of a primate embryonic stem cells line. Proceedings of the National Academy of Sciences of United States of America, v. 92, n. 17, p. 7844-7848, 1995.

THOMSON, J. A.; ITSKOVITZ - ELDOR, J.; SHAPIRO, S. S.; WAKNITZ, M. A.; SWIERGIEL, J. J.; MARSHALL, V. S.; JONES, J. M. Embryonic stem cells lines derived from human blastocysts. Science, v. 282, n. 5391, p. 1145-1147, 1998.

THOMSON, M.; LIU, S. J.; ZOU, L. N.; SMITH, Z.; MEISSNER. A.; RAMANATHAN, S. Pluripotency factors in embryonic stem cells regulate differentiation into germ layers. Cell, v. 145 , n. 6, p. 875-889, 2011.

TREMPUS, C. S.; MORRIS, R. J.; BORTNER, C. D.; COTSARELIS, G.; FAIRCLOTH, R. S.; REECE, J. M.; TENNANT, R. W. Enrichment for living murine keratinocytes from the hair follicle bulge with the cell surface marker CD34. The Journal of Investigative Dermatology, v. 120, n. 4, p. 501-511, 2003.

ULLAH, I.; SUBBARAO, R. B.; RHO, G. J. Human mesenchymal stem cells - current trends and future prospective. Bioscience Reports, v. 35, n. 2, p. 1-18, 2015.

VRAPCIU, A, D.; RUSU, M, C.; VOINEA, L, M. Immunohistochemistry of a choroidal melanoma: nestin, CD34 and CD117/c-kit labeling. The Journal of biological chemistry, v. 55, n. 2, p. 437-442, 2014. 
WANG, X. P.; SUOMALAINEN, M.; FELSZEGHY, S.; ZELARAYAN, L. C.; ALONSO, M. T.; PLIKUS, M. V.; MAAS, R. L.; CHUONG, C. M.; SCHIMMANG, T.; THESLEFF, I. An integrated gene regulatory network controls stem cell proliferation in teeth. Plos biology, v. 5, n. 6, p. 1324-1333, 2007.

WASEEM, A.; DOGAN, B.; TIDMAN, N.; ALAM, Y.; PURKIS, P.; JACKSON, S.; LALLI, A.; MACHESNEY, M.; LEIGH, I. M. Keratin 15 expression in stratified epithelia: downregulation in activated keratinocytes. The Journal of Investigative Dermatology, v. 112, n. 3, p. 362-369, 1999.

WATERS, J. M; RICHARDSON, G. D.; JAHODA, C. A. B. Hair follicle stem cells. Seminars in cell \& developmental biology, v. 18, n. 2, p. 245-254, 2007.

WONG, C. E.; PARATORE, C.; DOURS-ZIMMERMANN, M. T.; ROCHAT, A.; PIETRI. T.; SUTER, U.; ZIMMERMANN, D. R.; DUFOUR, S.; THIERY, J. P; MEIJER, D.; BEERMANN, F.; BARRANDON, Y.; SOMMER, L. Neural crest-derived cells with stem cell features can be traced back to multiple lineages in the adult skin. The Journal of Cell Biology, v. 175, n. 6, p. 1005-1015, 2006.

WU, G.; DENG, Z. H.; FAN, X. J.; MA, Z. F.; SUN, U. J.; MA, D. D.; WU, J. J.; SHI, J. N.; JIN, Y. Odontogenic potential of mesenchymal cells from hair follicle dermal papilla. Stem Cells Development, v 18, n 4, p. 583 - 589, 2009.

WU, M.; YANG, L.; LIU, S.; LI, H.; HUI, N.; WANG, F.; LIU, H. Differentiation potential of human embryonic mesenchymal stem cells for skin-related tissue. The British journal of dermatology, v. 155, n. 2, p. 282-291, 2006.

YANG, C. C.; COTSARELIS, G. Review of hair follicle dermal cells. Journal of Dermatological Science, v. 57, n. 1, p. 2-11, 2010.

YASHIRO, M.; MII, S.; AKI, R.; HAMADA, Y.; ARAKAWA, N.; KAWAHARA, K.; HOFFMAN, R. M.; AMOH, Y. From hair to heart: nestin-expressing hair-follicle-associated pluripotent (HAP) stem cells differentiate to beating cardic muscle cells. Cell cycle, v. 14, n. 14, p. 2362-2366, 2015.

YU, J.; THOMSON, J. A. Pluripotent stem cell lines. Genes and Development, v. 22, n. 15, p. 1987-1997, 2008.

YU, H.; FANG, D.; KUMAR, S. M.; LI, L.; NGUYEN, T. K.; ACS, G.; HERLYN, M.; XU, $\mathrm{X}$. Isolation of a novel population of multipotent adult stem cells from human hair follicles. The American journal of pathology, v. 168, n. 6, p. 1879-1888, 2006.

ZHANG, Y. V.; WHITE, B. S.; SHALLOWAY, D. I.; TUMBAR, T. Stem cell dynamics in mouse hair follicles: a story from cell division counting and single cell lineage tracing. Cell Cycle, v. 9, n. 8, p. 1504-1510, 2010.

ZHOU, X.; WANG, G.; SUN, Y. A reliable parameter to standardize the scoring of stem cell spheres. PLoS One, v. 10, n. 5, p. 1-13, 2015. 
ZHU, Q.; SAFAVI, K. E.; SPÅNGBERG, L. S. Integrin expression in human dental pulp cells and their role in cell attachment on extracellular matrix proteins. Journal of Endodontics, v. 24, n. 10, p. 641-644, 1998. 
APÊNDICES 


\section{A - Fixação e inclusão de material biológico em parafina}

- Fixação do material biológico com solução de formol 10\% em PBS - 48 horas;

- Formol/Etanol (1:1) - 1 hora;

- Etanol 70\% - 1 hora;

- Etanol 80\% - 1 hora;

- Etanol 95\% - 1 hora;

- Etanol 100\% - 1 hora;

- Etanol 100\% - 1 hora;

- Etano/Xilol (1:1) - 1 hora;

- Xilol 100\% - 1 hora;

- Xilol 100\% - 1 hora;

- Xilol 100\% - 1 hora;

- Parafina I - 1 hora;

- Parafina I - 1 hora; 
B - Coloração por hematoxilina - eosina

- Xilol I-20 minutos;

- Xilol II - 20 minutos;

- Etanol 100\% I - 2 minutos;

- Etanol 100\% II - 2 minutos;

- Etanol 95\% I - 2 minutos;

- Etanol 80\% I - 2 minutos;

- Etanol 70\% I - 2 minutos;

- Etanol 50\% I - 2 minutos;

- Lavar em água corrente - 2 minutos;

- Lavar em água destilada - 2 minutos;

- Hematoxilina de Harris - 2 minutos;

- Lavar em água corrente - 2 minutos;

- Lavar em água destilada - 2 minutos;

- Água amoniacal 0,5\% - 3 segundos;

- Lavar em água corrente - 2 minutos;

- Lavar em água destilada - 2 minutos;

- Etanol 50\% II - 2 minutos;

- Etanol 70\% II - 2 minutos;

- Etanol 80\% II - 2 minutos;

- Etanol 95\% II - 2 minutos;

- Eosina - 30 segundos;

- Etanol 95\% III - 2 minutos;

- Etanol 100\% III - 2 minutos;

- Etanol 100\% IV - 2 minutos;

- Etanol 100\% V - 2 minutos;

- Xilol III - 20 minutos;

- Xilol IV - 20 minutos;

- Xilol V - 20 minutos;

- Montagem 


\section{$\mathrm{C}$ - Protocolo de imunohistoquímica com fosfatase alcalina}

- Xilol I-20 minutos;

- Xilol II - 20 minutos;

- Etanol 100\% I - 2 minutos;

- Etanol 100\% II - 2 minutos;

- Etanol 95\% I - 2 minutos;

- Etanol 80\% I - 2 minutos;

- Etanol 70\% I - 2 minutos;

- Etanol 50\% I - 2 minutos;

- Lavar em água corrente - 2 minutos;

- Lavar em água destilada $2 \mathrm{x}-2$ minutos cada;

- Recuperação antigênica com tampão citrato (10 mM Acido Citrico, 0.05\% Tween 20, pH 6.0) - 35 minutos em banho maria $95-100{ }^{\circ} \mathrm{C}$;

- Desligar o banho maria deixando as lâminas no tampão citrato por 20 minutos;

- Lavar em água corrente - 2 minutos;

- Lavar 2 x em tampão PBS - 2 minutos cada;

- Bloqueio com solução de BSA 5\% em PBS - 30 minutos

- Aplicação do anticorpo primário diluído com solução de BSA 1\%, 0,01\% azida sódica em PBS. A diluição final é dada pelo fabricante. Incubação a $4{ }^{\circ} \mathrm{C}$, overnight.

- Lavar 2 x em tampão PBS - 2 minutos cada;

- Bloqueio da fosfatase endógena com solução de levamisol $5 \mathrm{mM}-2 \mathrm{x}, 10$ minutos cada.

- Lavar 2 x em tampão PBS - 2 minutos cada;

- Aplicar anticorpo secundário conjugado com fosfatase alcalina diluído com solução de BSA 1\%, 0,01\% azida sódica em PBS. Incubação em temperatura ambiente - 1 hora;

- Lavar 2 x em tampão PBS - 2 minutos cada;

- Revelar as lâminas com o cromógeno Fast red (Liquid Fast-Red Substrate Kit [AbCam - ab64254)]). Seguir orientações do kit;

- Lavar 2 x em água destilada - 2 minutos;

- Hematoxilina de Harris - 2 minutos;

- Lavar em água corrente - 2 minutos; 
- Lavar em água destilada - 2 minutos;

- Água amoniacal 0,5\% - 3 segundos;

- Lavar em água corrente - 2 minutos;

- Lavar em água destilada - 2 minutos;

- Secar as lâminas em estufa $37^{\circ} \mathrm{C}$;

- Montar as lâminas com Permount. 
ANEXOS 


\section{ANEXO}

Tabela 4 - Anticorpos utilizados.

\begin{tabular}{ll}
\hline \multicolumn{1}{c}{ Anticorpo } & \multicolumn{1}{c}{ Descrição } \\
\hline $\begin{array}{l}\text { Blimp } \\
\text { IgG policlonal de Cabra } \\
\text { (Santa Cruz) }\end{array}$ & $\begin{array}{l}\text { É um repressor transcricional que regula a diferenciação } \\
\text { de linfócitos B, mantêm a homeostase de linfócitos T } \\
\text { mantêm as células tronco da glândula sebácea } \\
\text { indiferenciadas. }\end{array}$ \\
$\begin{array}{l}\text { CD34 } \\
\text { IgG policlonal de Cabra } \\
\text { (Santa Cruz) }\end{array}$ & $\begin{array}{l}\text { Glicoproteína transmembrana expressa na superfície de } \\
\text { células tronco progenitoras presentes na protuberância de } \\
\text { folículo capilar. }\end{array}$ \\
$\begin{array}{l}\text { CD73 } \\
\text { IgG policlonal de Coelho } \\
\text { (Abcam) }\end{array}$ & $\begin{array}{l}\text { Proteína de membrana celular com ação enzimática } \\
\text { responsável em transformar AMP em adenosina e fosfato, } \\
\text { além de atuar na adesão celular regulando a interação da } \\
\text { célula com alguns componentes da matriz celular como } \\
\text { por exemplo, a laminina e fibronectina. }\end{array}$ \\
$\begin{array}{l}\text { CD90 } \\
\text { IgG policlonal de Rato } \\
\text { (Abcam) }\end{array}$ & $\begin{array}{l}\text { Molécula de adesão presente na membrana celular de } \\
\text { diferentes tipos celulares como as células tronco } \\
\text { mesenquimal, hematopoiética e dos queratinócitos e pode } \\
\text { ser encontrada também em fibroblastos, neurônios } \\
\text { células endoteliais ativas }\end{array}$ \\
\hline
\end{tabular}

CD105
IgG policlonal de Coelho
(Abcam)

\section{CK15}

IgG monoclonal de

Coelho

(Santa Cruz)

CKit
IgG policlonal de Coelho
(Santa Cruz)

Integrina $\alpha 6$

IgG policlonal de Coelho

(Santa Cruz)

LGR5
IgG policlonal de Cabra
(Santa Cruz)
LGR6
IgG policlonal de Coelho
(Santa Cruz)

\section{Lrig1 \\ IgG polyclonal de Cabra (Santa Cruz)}

\section{Nanog}

IgG policlonal de Cabra

(Santa Cruz)
Glicoproteína integral de membrana que é parte dos receptores para TGF $\beta$ e pode se associar também aos receptores para activina e proteína morfogenética óssea (BMP)

Filamento intermediário encontrado em células tronco da protuberância de folículos capilares.

\begin{tabular}{cc} 
Modo de ação & Diluição \\
\hline Marcação nuclear & $\begin{array}{c}\text { 1:50 BSA1\% em } \\
\text { PBS }\end{array}$ \\
& \\
& \\
$\begin{array}{c}\text { Marcação de } \\
\text { membrana }\end{array}$ & $\begin{array}{c}1: 50 \text { BSA1\% em } \\
\text { PBS }\end{array}$ \\
&
\end{tabular}

Marcação de membrana

1:300 BSA $1 \%$ em PBS

\section{Marcação de $\quad$ 1:300 BSA 1\% em} membrana PBS

$\begin{array}{cc}\begin{array}{c}\text { Marcação de } \\ \text { membrana }\end{array} & \begin{array}{c}\text { 1:300 BSA 1\% em } \\ \text { PBS }\end{array} \\ & \\ \begin{array}{c}\text { Marcação } \\ \text { citoplasmática }\end{array} & \begin{array}{c}1: 50 \text { BSA1\% em } \\ \text { PBS }\end{array}\end{array}$

Proteína de membrana encontrada em células que se originam da crista neural

$\begin{array}{cc}\begin{array}{c}\text { Marcação de } \\ \text { membrana }\end{array} & \begin{array}{c}1: 50 \text { BSA1\% em } \\ \text { PBS }\end{array} \\ \begin{array}{c}\text { Marcação de } \\ \text { membrana }\end{array} & \begin{array}{c}1: 50 \text { BSA1\% em } \\ \text { PBS }\end{array}\end{array}$

Receptor transmembrana elvolvido na interação célulal célula, ou célula - matrix.

membrana

PBS

Receptor transmembrana no controle e diferenciação celular de embriões. É encontrado também em células indiferenciadas da protuberância de folículos capilares.

$\begin{array}{cc}\begin{array}{c}\text { Marcação de } \\ \text { membrana }\end{array} & \begin{array}{c}1: 50 \text { BSA1\% em } \\ \text { PBS }\end{array} \\ \begin{array}{c}\text { Marcação de } \\ \text { membrana }\end{array} & \begin{array}{c}1: 50 \mathrm{BSA} 1 \% \mathrm{em} \\ \text { PBS }\end{array}\end{array}$

Receptor transmembrana no controle e diferenciação celular de embriões. É encontrado também em células indiferenciadas da protuberância de folículos capilares.

Proteína de membrana que age como antagonista ao receptor do fator de crescimento epidermal (EGFR).

$\begin{array}{cc}\begin{array}{c}\text { Marcação de } \\ \text { membrana }\end{array} & 1: 50 \text { BSA1\% em } \\ \text { PBS }\end{array}$

Genes reguladores transcricionais envolvidos na decisão do destino celular durante o desenvolvimento.

Marcação nuclear.

1:100 BSA $1 \%$ em PBS

Filamento intermediário de células progenitoras do sistema nervoso central de embriões. Utilizado para marcar células tronco neuroepiteliais.

$\begin{array}{cc}\begin{array}{c}\text { Marcação } \\ \text { citoplasmática }\end{array} & \begin{array}{c}1: 50 \text { BSA1\% em } \\ \text { PBS }\end{array} \\ \text { Marcação nuclear. } & \begin{array}{c}1: 150 \text { BSA } 1 \% \text { em } \\ \text { PBS }\end{array}\end{array}$

Fator de transcrição expresso nas fases iniciais do desenvolvimento (mórula, blastocisto), está relacionado com a manutenção de pluripotencialidade das célulastronco embrionárias e ou pluripotentes. 


\begin{tabular}{|c|c|c|c|}
\hline $\begin{array}{l}\text { Sox-2 } \\
\text { IgG policlonal de Cabra } \\
\text { (Santa Cruz) }\end{array}$ & $\begin{array}{l}\text { Genes reguladores transcricionais envolvidos na decisão } \\
\text { do destino celular durante o desenvolvimento. }\end{array}$ & Marcação nuclear. & $\begin{array}{l}\text { 1:100 BSA } 1 \% \text { em } \\
\text { PBS }\end{array}$ \\
\hline Anti - Cabra Alexa633 & $\begin{array}{l}\text { Imunoglobulinas G (IgG), isoladas do soro de burro, } \\
\text { conjugadas com fluoróforo alexa } 633^{\circledR} \text {. }\end{array}$ & $\begin{array}{l}\text { Revelação do } \\
\text { anticorpo primário }\end{array}$ & $\begin{array}{l}\text { 1:300 BSA } 1 \% \text { em } \\
\text { PBS }\end{array}$ \\
\hline Anti - Cabra FITC & $\begin{array}{l}\text { Imunoglobulinas } \mathrm{G} \text { (IgG), isoladas do soro de burro, } \\
\text { conjugadas com fluoróforo FITC. }\end{array}$ & $\begin{array}{l}\text { Revelação do } \\
\text { anticorpo primário }\end{array}$ & $\begin{array}{l}1: 300 \text { BSA } 1 \% \text { em } \\
\text { PBS }\end{array}$ \\
\hline Anti - Coelho Alexa633 & $\begin{array}{l}\text { Imunoglobulinas G (IgG), isoladas do soro de burro, } \\
\text { conjugadas com fluoróforo alexa } 633^{\circledR} \text {. }\end{array}$ & $\begin{array}{l}\text { Revelação do } \\
\text { anticorpo primário }\end{array}$ & $\begin{array}{l}\text { 1:300 BSA } 1 \% \text { em } \\
\text { PBS }\end{array}$ \\
\hline Anti - Coelho FITC & $\begin{array}{l}\text { Imunoglobulinas G (IgG), isoladas do soro de cabra, } \\
\text { conjugadas com fluoróforo FITC. }\end{array}$ & $\begin{array}{l}\text { Revelação do } \\
\text { anticorpo primário }\end{array}$ & $\begin{array}{l}1: 300 \text { BSA } 1 \% \text { em } \\
\text { PBS }\end{array}$ \\
\hline Anti - Rato FITC & $\begin{array}{l}\text { Imunoglobulinas G (IgG), isoladas do soro de cabra, } \\
\text { conjugadas com fluoróforo FITC. }\end{array}$ & $\begin{array}{l}\text { Revelação do } \\
\text { anticorpo primário }\end{array}$ & $\begin{array}{c}\text { 1:300 BSA } 1 \% \text { em } \\
\text { PBS }\end{array}$ \\
\hline
\end{tabular}




\section{ANEXO}

Tabela 5 - Primers utilizados.

\begin{tabular}{|c|c|c|c|c|c|c|}
\hline Target & $\begin{array}{c}\text { Primer } \\
\text { Sequence 5 }-\rightarrow \text { 3, }\end{array}$ & $\begin{array}{l}\mathbf{T m} \\
\left({ }^{\circ} \mathbf{C}\right)\end{array}$ & $\begin{array}{c}\text { GC } \\
\%\end{array}$ & $\begin{array}{c}\text { Self } \\
\text { Compl. }\end{array}$ & $\begin{array}{l}\text { 3'- Self } \\
\text { Compl. }\end{array}$ & $\begin{array}{l}\text { Product } \\
\text { (bp) }\end{array}$ \\
\hline $\begin{array}{l}\text { Nanog } \\
\text { Mus } \\
\text { musculus }\end{array}$ & $\begin{array}{l}\text { F: TACCTCAGCCTCCAGCAGAT } \\
\text { R: GGTGCTGAGCCCTTCTGAAT }\end{array}$ & $\begin{array}{l}60.03 \\
60.03\end{array}$ & $\begin{array}{l}55.00 \\
55.00\end{array}$ & 5.00 & 3.00 & 161 \\
\hline $\begin{array}{c}\text { Oct4 } \\
\text { Mus } \\
\text { musculus }\end{array}$ & $\begin{array}{l}\text { F: CACCATCTGTCGCTTCGAGG } \\
\text { R: AGGGTCTCCGATTTGCATATCT }\end{array}$ & $\begin{array}{l}60.80 \\
59.02\end{array}$ & $\begin{array}{l}60.00 \\
45.45\end{array}$ & 8.00 & 6.00 & 132 \\
\hline $\begin{array}{c}\text { Sox2 } \\
\text { Mus } \\
\text { musculus }\end{array}$ & $\begin{array}{l}\text { F: ACAGCATGTCCTACTCGCAG } \\
\text { R: CCTCGGACTTGACCACAGAG }\end{array}$ & $\begin{array}{l}59.00 \\
61.00\end{array}$ & $\begin{array}{l}55.00 \\
60.00\end{array}$ & $\begin{array}{l}4.00 \\
3.00\end{array}$ & 1.00 & 75 \\
\hline $\begin{array}{l}\text { SSEA-1 } \\
\text { Mus } \\
\text { musculus }\end{array}$ & $\begin{array}{l}\text { F: GCTGTCTATCGCCGCTACTT } \\
\text { R: TGCCAAGTTGTGGATGCTCT }\end{array}$ & $\begin{array}{l}60.00 \\
62.00\end{array}$ & $\begin{array}{l}55.00 \\
50.00\end{array}$ & $\begin{array}{l}5.00 \\
5.00\end{array}$ & $\begin{array}{l}0.00 \\
0.00\end{array}$ & 138 \\
\hline $\begin{array}{l}\text { 及-Actin } \\
\text { Mus } \\
\text { musculus }\end{array}$ & $\begin{array}{l}\text { F: GCTCCGGCATGTGCAAAG } \\
\text { R: CСТTCTGACCСАTTCCСАCC }\end{array}$ & $\begin{array}{l}59.82 \\
60.03\end{array}$ & $\begin{array}{l}61.11 \\
60.00\end{array}$ & 3.00 & $\begin{array}{l}2.00 \\
0.00\end{array}$ & 114 \\
\hline $\begin{array}{l}\text { GAPDH } \\
\text { Mus } \\
\text { musculus }\end{array}$ & $\begin{array}{l}\text { F: GTCATCATCTCCGCCCCTTC } \\
\text { R: AGTGATGGCATGGACTGTGG }\end{array}$ & $\begin{array}{l}62.00 \\
60.00\end{array}$ & $\begin{array}{r}60.00 \\
55.00\end{array}$ & $\begin{array}{l}3.00 \\
5.00\end{array}$ & $\begin{array}{l}0.00 \\
0.00\end{array}$ & 192 \\
\hline
\end{tabular}

